\author{
Universidade de São Paulo
}

Faculdade de Medicina de Ribeirão Preto

Departamento de Farmacologia

\title{
Papel do receptor toll- like 9 na falência de migração dos neutrófilos na sepse
}

Silvia Cellone Trevelin

Ribeirão Preto 
Silvia Cellone Trevelin

\section{Papel do receptor toll- like 9 na falência de}

\section{migração dos neutrófilos na sepse}

Dissertação apresentada à Faculdade de Medicina de Ribeirão Preto da Universidade de São Paulo para a obtenção do título de Mestre em Ciências.

Área de concentração: Farmacologia

Orientador: Prof. Dr. Fernando de Queiroz Cunha

Co-Orientador: Dr. José Carlos Alves-Filho

Ribeirão Preto 
Autorizo a reprodução e divulgação total ou parcial deste trabalho, por qualquer meio convencional ou eletrônico, para fins de estudo e pesquisa, desde que citada à fonte.

\section{Ficha Catalográfica}

Trevelin, Silvia Cellone

Papel do receptor toll- like 9 na falência de migração dos neutrófilos na sepse.

Ribeirão Preto, 2010.

$131 \mathrm{p}$.

Dissertação de mestrado apresentada ao Programa de Pós-Graduação em Ciências. Área de concentração: Farmacologia- Faculdade de Medicina de Ribeirão Preto da Universidade de São Paulo.

Orientador: Fernando de Queiroz Cunha

Co-Orientador: José Carlos Alves-Filho

Palavras Chaves: Ligadura e perfuração do ceco (CLP), polimorfonucleares, CXCR2, GRK2, dessensibilização, quimiotaxia, migração de neutrófilos, receptor toll-like 9. 
Silvia Cellone Trevelin

Papel do receptor toll- like 9 na falência de migração dos neutrófilos na sepse

Aprovado em:

\section{Banca examinadora:}

Prof. Dr. Fernando de Queiroz Cunha

Instituição: FMRP-USP

Assinatura:

Prof. Dr. Marcos Antonio Rossi

Instituição: FMRP-USP

Assinatura:

Prof. Dr. Ricardo Tostes Gazzinelli

Instituição: CPqRR- FIOCRUZ

Assinatura: 
Trabalho realizado no Laboratório de Dor e Inflamação do Departamento de Farmacologia da Faculdade de Medicina de Ribeirão Preto - Universidade de São Paulo com auxílio financeiro da Coordenação de Aperfeiçoamento de Pessoal de Nível Superior (CAPES). 
Dedicatória 
Dedico esta dissertação aos meus amados pais, Edison Osmar Trevelin e Silvia Mara Cellone Trevelin, pois mais que a vida, me proporcionaram o desejo e a busca por conhecimento, apoiando-me em todos os momentos em que mais precisei. Agradeço aos dois por serem as pernas que me movimentam e me permitem seguir em frente, mesmo enfrentando inúmeras adversidades. 
Agradecimentos 
Agradeço inicialmente ao Prof. Fernando de Queiroz Cunha pela amizade e orientação, por abrir as portas do laboratório de Inflamação, me oferecendo todo apoio e infra-estrutura para a realização deste trabalho. Obrigada também ao Prof. Sérgio Henrique Ferreira, que junto ao professor Fernando colaborou para minha formação pessoal e profissional.

Grata ao professor Ricardo T. Gazzinelli, da FIOCRUZ, por fornecer o agonista do receptor toll-like 9, o que permitiu a realização da grande maioria dos experimentos referenciados neste trabalho. Bem como ao Prof. João Santana, do Departamento de Bioquímica e Imunologia desta Faculdade, por ter cedido os animais deficientes do receptor toll-like 9.

Sou grata aos que colaboraram diretamente com meu trabalho, por meios de discussões, ensinamento de técnicas as quais eu não tinha domínio, ou mesmo, a realização direta de experimentos ao meu lado: José Carlos Alves-Filho, Fabiane Sônego, Walter Turato, Daniele Carvalho Nascimento, Fabricio Oliveira Souto e Thiago Cunha.

Obrigada aos meus colegas dos laboratórios de Dor e Inflamação, que não realizaram experimentos propriamente neste trabalho, mas contribuíram em grande parte para a minha formação pessoal e profissional: Larissa Garcia Pinto, Paula Giselle Czaikoski, Rafael Sanches Peres, Fernanda Castanheiras, Jhimmy Talbot, Jaqueline Raymond, Alexandre Kanashiro, Adriana de Souza, Daniela Carlos, Jozi Godoy, Andressa Daine de Carvalho Zaparoli, Cristina Freitas, Vanessa Carregaro, Guilherme Rabelo de Sousa, Rafael Poloni, Thiago Garlet, Sabrina Aquino, Paula Barbim, Romualdo Sousa, Maria do Carmo, Livia Harumi Yamashiro. 
Grata aos colegas que me deram a oportunidade de trabalhar em colaboração para o desenvolvimento de seus respectivos trabalhos e auxiliaram no meu aprendizado como pesquisadora: Andressa Freitas, Daniela Carlos, Lilian Rodrigues, Adriana de Souza, Fabricio Oliveira Souto, Fernanda Castanheiras.

Agradeço aos colegas que já passaram pelo laboratório e agora seguem suas vidas em outros locais, mas contribuíram em muito para minha formação como pesquisadora, além da grande amizade: Silvio Manfredo, Andressa de Freitas, Renata Grespan, Henrique Lemos, Fernando Spiller, Sandra Yasuyo Fukada, Paulo Barboni, Waldiceu Aprecido Verri Junior, Daniela Dal Secco, Flávia Lima.

Obrigada aos colegas de outros laboratórios que trabalham em colaboração com o Professor Fernando, com os quais travei grande amizade: Letícia, Roberto, Heitor, Sandrina Carla, Frederico, Thayna, Caio, Ana Carla.

Grata aos alunos e ex-alunos de Iniciação Científica, pela contribuição a minha formação profissional, bem como a amizade: Ana Elisa, Fernanda, Camila, Eleonora, Laís, Francine, Marina, Rafaela, Victor, Flávia.

Grata as amigas estagiárias do laboratório e futuras colegas de trabalho: Andressa Duarte, Vanessa Borges.

Obrigada a todos os Pós-graduandos do Departamento de Farmacologia, pela amizade, discussões durante as disciplinas que cursamos juntos, pelos encontros no corredor, pelo curso de inverno que realizamos com sucesso no ano de 2009 e neste ano de 2010 .

Grata a todos os Docentes do Departamento de Farmacologia, que construíram os laboratórios, equipando-os por meio de seus esforços na realização de inúmeros 
trabalhos reconhecidamente publicados em revistas de excelência, o que também permitiu a notável classificação do Programa de Pós-Graduação em Farmacologia junto a CAPES. Em especial, agradeço aos professores Francisco Guimarães, Fernando de Queiroz Cunha e Fernando Morgan pelo cuidado ao ministrarem as disciplinas que cursei dentro deste Departamento. Tais disciplinas me trouxeram inúmeros conhecimentos, entre eles, o desenvolvimento de um raciocínio crítico que muito contribuiu para a realização deste trabalho.

Grata aos docentes do Departamento de Biologia Celular e Molecular, bem como do Departamento de Bioquímica e Imunologia, pelas disciplinas extremamente enriquecedoras as quais cursei e que contribuíram em muito para meu aprendizado como pesquisadora.

Obrigada a todos os alunos e docentes que fazem parte do Journal Club pelo Programa de Pós-Graduação em Imunologia Básica e Aplicada, pelas ricas discussões de artigos que muito contribuíram para minha formação profissional.

Agradeço a imensa amizade, além do auxílio técnico de: Diva Amábile, Ana Kátia dos Santos, Fabíola Leslie Mestriner, Sérgio Roberto Rosa, Giuliana Bertozi, Tadeu Franco Vieira, Denise Brufato Ferraz, Ieda Regina dos Santos, Silvana Chedraoui Silva. Grata ao meu amigo da administração Acácio Antunes Cardoso Filho.

Obrigada as bioteristas pelo cuidado com os animais e pela amizade: Maria Inês Nemoto e Eliana Beatriz Castrechini.

Grata aos colegas que trabalham na secretaria dos departamentos de Farmacologia, Biologia Celular e Molecular, Bioquímica e Imunologia: José Waldik Ramon, Sonia Maria Stefanelli de Andrade, Fátima Pestean, Ana Cristine, Rosangela. 
Agradeço a Fabricio Oliveira Souto não apenas pela ajuda e ensinamentos que possibilitaram a realização deste trabalho, mas também pela grande amizade, paciência e carinho com que sempre me tratou.

Obrigada aos membros da banca examinadora composta por: Prof. Dr. Ricardo Gazzinelli, Prof. Dr. Marcos Antonio Rossi e Prof. Dr. Fernando de Queiroz Cunha por se dispuserem a atender meu pedido quanto à avaliação deste trabalho.

Agradeço em muito a Instituição CAPES pelo auxílio financeiro que possibilitou a realização deste trabalho.

Por fim, sou imensamente grata a aquele que propiciou tudo o que estudei, e que estudo, a aquele que me deu a vida e ainda todo amparo que preciso para construíla, obrigada a DEUS, meu pai e guia para todas as horas, amigo e companheiro para toda a vida. 
"Olhai os lírios do campo, eles não tecem, eles não fiam, porém nem Salomão com toda sua glória conseguiu vestir-se como qualquer um deles" (Jesus Cristo). 
Resumo 


\section{TREVELIN, S.C. Papel do receptor toll-like 9 na falência de migração dos}

neutrófilos na sepse. Dissertação de mestrado- Departamento de Farmacologia da Faculdade de Medicina de Ribeirão Preto- Universidade de São Paulo, Ribeirão Preto, SP.

O recrutamento de neutrófilos para o sítio da infecção é um evento crucial para o combate aos microrganismos e sobrevivência na sepse. A migração destes polimorfonucleares é dirigida através de um gradiente quimiotático por meio do reconhecimento de quimiocinas por receptores acoplados a proteína G (GPCRs), os quais são regulados por quinases específicas (GRKs). Estudos prévios demonstraram que na sepse ocorre uma falência na migração de neutrófilos para o foco infeccioso em função da dessensibilização de receptores quimiotáticos via GRKs induzida pela ativação de receptores "toll-like" (TLRs), TLR2 e TLR4. Apesar de a ausência de TLR9 em células dendriticas ter sido relacionada a maior sobrevivência de camundongos sépticos, o papel de TLR9 atuando diretamente em neutrófilos não foi avaliado. Objetivando preencher esta lacuna, propôs-se avaliar o papel direto de TLR9 na falência de migração de neutrófilos na sepse. Os camundongos TLR9 ${ }^{-/}$apresentaram maior sobrevivência a sepse polimicrobiana avaliada por meio do modelo de ligadura e perfuração do ceco (CLP). A deficiência de TLR9 também acarretou em aumento na migração de neutrófilos para o foco da infecção, menor seqüestro de neutrófilos no pulmão, bem como, menor número de bactérias no lavado peritoneal e sangue. A ativação de TLR9 por oligodeoxinucleotídeo contendo o dinucleotídeo CpG não metilado (ODN CpG) nos neutrófilos reduziu a quimiotaxia destes em direção a quimiocina CXCL2 e expressão do receptor quimiotático CXCR2. Além disso, neutrófilos estimulados com ODN CpG apresentaram aumento na expressão da quinase 
tipo 2 relacionada a receptores acoplados a proteína G (GRK2). Dessa forma, a ativação de TLR9 em neutrófilos circulantes no sangue é prejudicial na sepse por reduzir a quimiotaxia destes para o foco da infecção ao induzir a dessensibilização de CXCR2 via GRK2.

Palavras chave: Ligadura e perfuração do ceco (CLP), polimorfonucleares, CXCR2, GRK2, dessensibilização, quimiotaxia, migração de neutrófilos, receptor toll-like 9. 
Abstract 


\section{TREVELIN, S.C. The role of toll-like receptor 9 on failure of neutrophil migration}

during sepsis. Thesis (Master) - Department of Pharmacology of School of Medicine of Ribeirão Preto - University of São Paulo, Ribeirão Preto, SP.

The recruitment of neutrophils to the site of infection is a crucial event for combating the microorganisms and survival on sepsis. The neutrophil migration is directed by a chemotactic gradient through the recognition of chemokines by $\mathrm{G}$ protein-coupled receptors (GPCRs), which are regulated by specific kinases (GRKs). Previous studies have shown a failure of neutrophil migration into infectious focus on sepsis due to chemotactic receptor desensitization via GRKs induced by activation of toll- like receptors (TLRs), TLR2 and TLR4. Despite the absence of activation of TLR9 in dendritic cells have been related to increase survival of septic mice, the role of TLR9 acting directly on neutrophils was not evaluated. We proposed to verify the direct role of TLR9 in the failure of neutrophil migration on sepsis. The TLR9 knockout mice $\left(\mathrm{TLR}^{-/}\right)$showed high survival to polymicrobial sepsis using cecal ligation and puncture model (CLP). TLR9 ${ }^{-/-}$mice had high neutrophil migration to the focus of infection, low neutrophil sequestration in the lung, as well as, few bacteria in the peritoneal exudates and blood. The activation of TLR9 by oligodeoxinucleotide containing unmethylated dinucleotide $\mathrm{CpG}(\mathrm{CpG} \mathrm{ODN})$ in neutrophils also reduced chemotaxis toward CXCL2 and the expression of chemokine receptor CXCR2. In addition, neutrophils stimulated with $\mathrm{CpG}$ ODN showed increased expression of kinaserelated $G$ protein-coupled receptor type 2 (GRK2). Thus, the activation of TLR9 in blood circulating neutrophils is harmful on sepsis by reducing their chemotaxis into the site of the infection by inducing CXCR2 desensitization via GRK2. 
Key words: Cecal ligation and puncture (CLP), polimorphonuclear, CXCR2, GRK2, dessensitization, chemotaxis, neutrophil migration, toll-like-receptor 9. 


\section{Lista de abreviaturas}


AA:

BHI:

BSA:

CLP:

CXCR2:

DNA:

EDTA:

GRK2:

ICAM:

IgG:

IL:

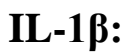

i.p.:

i.v.:

IFN- $\gamma$ :

KC/CXCL1:

KCl:

KH2PO4

Kg:

KO:

L:

LPS:

LTA:

LTB4:

MIP-2/CXCL2:
Aminoácido

Meio de cultura Brain heart infusion

Albumina sérica bovina

Ligadura e perfuração do ceco

Receptor quimiotático para CXCL1 e CXCL2

Ácido desoxirribonucléico

Ácido etilenodiaminotetracético

Quinase tipo 2 associada a receptor acoplado a proteína G

Molécula de adesão intercelular

Imunglobulina G

Interleucina

Interleucina 1 beta

Intraperitoneal

Intravenoso

Interferon- gama

Quimiocina derivada de queratinócito

Cloreto de potássio

Fosfato de potássio monobásico

Quilograma

Nocaute (Knockout)

Litro

Lipopolissacarideo derivado de $E$. coli cepa 0157

Ácido lipoteicóico

Leucotrieno B 4

Proteína Inflamatória derivada de macrófago 2 
mL: $\quad$ mililitro

MPO: $\quad$ Mieloperoxidase

$\mu \mathrm{L}: \quad$ Microlitro

NaCl: $\quad$ Cloreto de sódio

Na2HPO4 Fosfato de sódio dibásico

NaOH: $\quad$ Hidróxido de sódio

NFк-B Fator de transcrição nuclear Kappa B

NO: $\quad$ Óxido nítrico

NS-CLP Sepse não severa

ODN: $\quad$ Oligodeoxinucleotídeo

ODN CpG: $\quad$ Oligodeoxinucleotídeo contendo o dinucleotídeo CpG não metilado

PAMPs Padrões moleculares associados a patógenos

PBS: $\quad$ Solução salina tamponada fosfatada

pmol: $\quad$ picomol

RNA: $\quad$ Ácido ribonucléico

ROS: $\quad$ Espécies reativas derivadas de oxigênio

S-CLP: $\quad$ Sepse severa

S.c.: $\quad$ Sub-cutâneo

TLR: $\quad$ Toll-like receptor

TNF-alfa: $\quad$ Fator de necrose tumoral alfa

UFC: $\quad$ Unidade formadora de colônia

VCAM: $\quad$ Molécula de adesão vascular 
Sumário 
1. Introdução.......................................................................................................

1.1 Importância dos neutrófilos no combate a infecção....................................... 27

1.2 Receptores que sinalizam a presença de patógenos......................................... $\mathbf{3 0}$

1.3 Falência da migração dos neutrófilos na sepse........................................... $\quad 35$

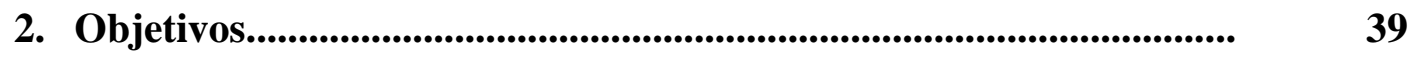

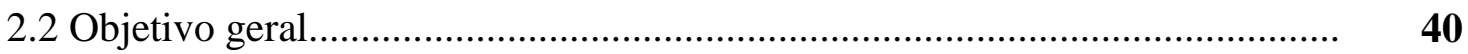

2.3 Objetivos Específicos.............................................................................. 41

3. Material e métodos................................................................................... 44

3.1 Preparo de soluções............................................................................ 45

3.2 Oligodeoxinucleotídeos e anticorpos......................................................... $\quad 48$

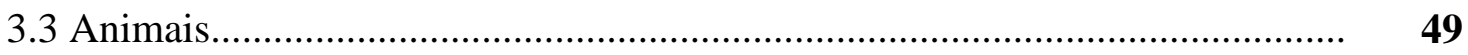

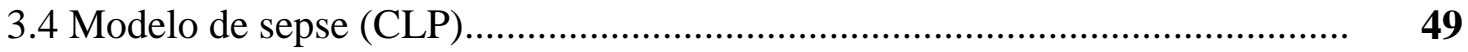

3.5 Migração de neutrófilos para o foco de inflamação/infecção............................ $\mathbf{5 0}$

3.6 Microscopia intravital....................................................................... 51

3.7 Quantificação bacteriana...................................................................... 51

3.8 Dosagem de citocinas........................................................................... $\quad 52$

3.9 Mensuração dos neutrófilos no tecido pulmonar.............................................. 53

3.10 Isolamento de neutrófilos do sangue e medula óssea.................................... $\quad 54$

3.11 Quimiotaxia de neutrófilos...................................................................... 54

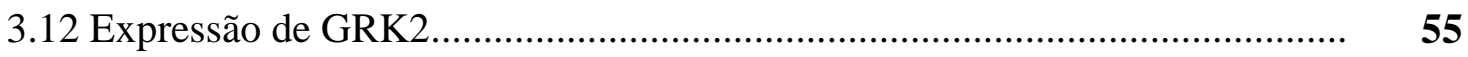

3.13 Polimerização de actina............................................................................ 56

3.14 Ensaio de "Killing”, .................................................................................. 5

3.15 Ensaio de fagocitose ............................................................................. 58

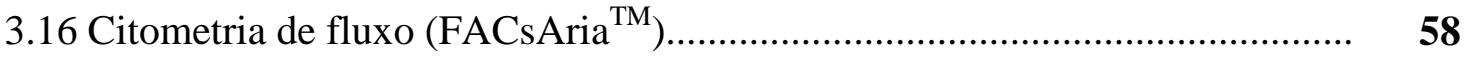

3.17 Ensaio de transferência adotiva.................................................................. 
3.18 Produção de óxido nítrico (NO) .............................................................. 63

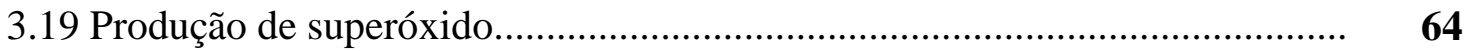

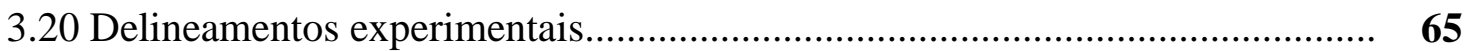

3.21 Análise dos resultados.....................................................................

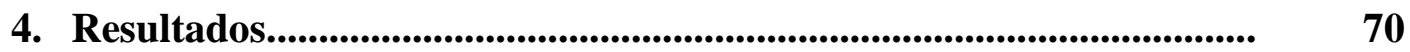

4.1 Camundongos deficientes de TLR9 foram mais resistentes a CLP.................. $\mathbf{7 1}$

4.2 Neutrófilos de camundongo expressam TLR9 ........................................... 78

4.3 A ativação de TLR9 inibiu a migração de neutrófilos para o foco da inflamação

4.4 A ativação de TLR9 em neutrófilos prejudica a quimiotaxia para CXCL2.......

4.5 A ativação de TLR9 induz a internalização CXCR2 via GrK2 em neutrófilos...

4.6 A ativação de TLR9 aumenta a capacidade microbicida de neutrófilos

4.7 A ativação de TLR9 aumenta a produção de ROS e potencializa a produção de

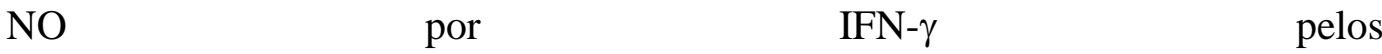
neutrófilos

5. Discussão............................................................................................ 107

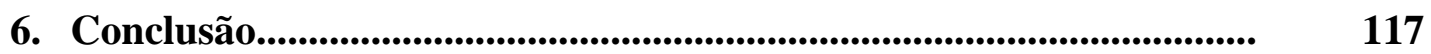

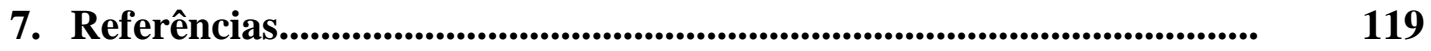

8. Anexos............................................................................................................... 132 
1. Introdução 


\subsection{Importância dos neutrófilos no combate a infecção}

Os neutrófilos são leucócitos polimorfonucleados essenciais no funcionamento do sistema imunológico. Sob estímulo, expressam receptores de membrana responsáveis pela aderência e migração através do endotélio vascular, se dirigindo por quimiotaxia ao sítio da infecção. Após o neutrófilo realizar a fagocitose, no interior do endolisossomo há a morte do agente infeccioso por meio de enzimas e agentes oxidantes (Janeway et al., 2007). Por serem a primeira linha de defesa contra os microrganismos, qualquer falha no recrutamento dos neutrófilos está associada à permanência da infecção, invasão do agente a corrente circulatória e reação inflamatória sistêmica culminando com a morte do indivíduo (Brown et al., 2006). O entendimento das vias de ativação, sinalização e mobilização dos neutrófilos auxiliam identificar alvos terapêuticos para seletivamente inibir ou ativar determinadas funções (Zarbock e Ley, 2008).

Durante uma infecção há liberação local e sistêmica de mediadores inflamatórios, tais como óxido nítrico, histamina e prostaglandinas (Rang et al., 2007). Tais mediadores promovem vasodilatação e consequiente redução na velocidade do fluxo sanguíneo que resulta no deslocamento dos neutrófilos para a periferia dos vasos, fenômeno denominado marginação. Após a marginação, há o rolamento dos neutrófilos, por meio da expressão de receptores na membrana das células endoteliais denominados selectinas, que interagem com grupos de carboidratos específicos na superfície dos leucócitos (Alves-Filho et al., 2010b). Existem basicamente três tipos de selectinas: endotelial $(\mathrm{E})$, plaquetária $(\mathrm{P})$ e leucocitária (L). A P-selectina é sintetizada continuamente pelas células e 
secretada em grânulos citoplasmáticos, enquanto a E-selectina é produzida somente quando da indução por citocinas tais como IL-1beta e TNF-alfa (Chandra et al., 2006). Posterior ao rolamento dá-se a adesão firme entre o endotélio e os leucócitos mediada por integrinas. Este último evento decorre da maior afinidade entre o heterodímero constituído por alfa e $\beta$-integrinas dos leucócitos com seus respectivos ligantes no endotélio, tais como LFA-1, e VLA-4 pelos neutrófilos, que interagem com ICAM e VCAM das células endoteliais (Abbas e Lichtman, 2005).

Após a saída dos neutrófilos dos vasos sanguíneos, os mesmos se dirigem para o foco da infecção guiados por um gradiente quimiotático, o qual pode ser formado por quimiocinas, leucotrieno B4 (LTB4), C5a (anafilatoxina) e componentes bacterianos, como peptídeos formilados (Janetopoulos e Firtel, 2008). Segundo Alves-Filho et al. (2009), os receptores para quimiocinas exercem grande importância no recrutamento de neutrófilos para o foco da infecção por atuarem aumentando a afinidade entre integrinas do endotélio e leucocitárias, além de apropriamente guiarem os leucócitos para o local da inflamação.

Os receptores quimiotáticos são constituídos por sete domínios transmembrânicos acoplados a proteína Gi (inibe a adenilato ciclase) e são regulados por proteínas quinases associadas (GRKs). Segundo Janetopoulos e Firtel (2008), a interação do agonista com o receptor quimiotático, e resultante ativação da proteína $\mathrm{G}$ acoplada, acarreta no recrutamento da fosfatidilinositol 3kinase (PI3K) e na produção de PIP3 (fosfatidil-inositol-trifosfato), o qual governa a polimerização de actina no pólo frontal da célula para a formação do lamelipódio, enquanto a fosfatase PTEN dirige a contração da célula no pólo 
caudal, uropódio. Dessa forma, o processo de polimerização de actina no lamelipódio frontal e despolimerização caudal, bem como atuação da miosina II no pólo caudal permite a movimentação amebóide do neutrófilo do vaso sanguíneo até o local da inflamação.

Já no sítio da infecção, os formilpeptídeos derivados de bactérias, C5a, LTB4 e citocinas liberadas localmente estimulam os neutrófilos a sofrerem uma “explosão respiratória", na qual uma grande quantidade de oxigênio molecular é consumida para geração de superóxido por meio do complexo NADP oxidase. A partir do superóxido são geradas outras espécies reativas, tais como peróxido de hidrogênio $\left(\mathrm{H}_{2} \mathrm{O}_{2}\right)$, radicais hidroxila $\left(\mathrm{OH}^{-}\right)$e compostos halogenados (Babior et al., 2004; Sheppard et al. 2005). Os compostos derivados do oxigênio (ROS) são espécies consideradas altamente reativas liberadas primariamente no interior dos fagolisossomos, onde se combinam rapidamente com proteínas microbianas e lipídeos, resultando na oxidação dos mesmos (Ritter et al., 2003). Eles também são liberados no citosol, onde alteram o estado "redox" da célula e oxidam componentes celulares, alterando sua função (Macdonald et al., 2003). Sob condições patológicas, tais radicais são liberados no meio extracelular, onde são responsáveis pelo dano tecidual durante uma resposta inflamatória não controlada (Novelli, 1998).

Além dos ROS, os neutrófilos produzem compostos derivados de nitrogênio (RNS), como o óxido nítrico (NO) e peroxinitrito, que também participam dos mecanismos microbicidas (Tsukahara et al., 2001). O NO é produzido pela enzima óxido nítrico sintase (NOS) a partir da L-arginina e do NADPH. Existem três isoformas de NOS: neuronal (nNOS), endotelial (eNOS) e induzida (iNOS), 
sendo a última expressa nos fagócitos sobre estímulo de citocinas, tais como IL-

1beta e IFN-gama, além de outros mediadores pró-inflamatórios (Rang et al., 2007).

\subsection{Receptores que sinalizam a presença de patógenos}

Embora o sistema imune inato não possua a especificidade fina do sistema imune adaptativo necessária para produzir a memória imunológica, ele é capaz de distinguir o próprio do não próprio (Janeway et al, 2007). Sua ativação ocorre quando as células são expostas a padrões moleculares associados à patógenos (PAMPs) expressos por diversos grupos de microrganismos infecciosos (Kono e Rock., 2008).

Receptores “toll-like” (TLRs) são proteínas transmembranas evolutivamente conservadas em insetos e vertebrados, sendo essenciais para o reconhecimento de PAMPs (Abbas e Lichtman, 2005). Eles são estruturalmente definidos por repetições ricas em leucina em seu domínio extracelular, e um domínio de sinalização citoplasmático homólogo ao receptor de IL-1beta, denominado domínio TIR (toll-like and IL-1 receptor) (Akira e Takeda, 2004). Foram identificados ao menos treze tipos de TLRs, cuja sinalização é critica para o desenvolvimento da resposta imune inata e adaptativa. TLR1, 2, 4, 5, 6, 10 e 11 são expressos na superfície dos fagócitos e reconhecem lipoproteínas, peptidoglicano, zimosan (TLR2 quando associado a TLR1 e 6), lipopolissacarídeo (TLR4) e flagelina (TLR5). Os TLR3, 7, 8 e 9 estão localizados em compartimentos intracelulares e reconhecem RNA (ácido 
ribonucléico) de fita dupla, RNA de fita simples, DNA (ácido desoxirribonucléico) não metilado, respectivamente (El Kebir et al., 2008).

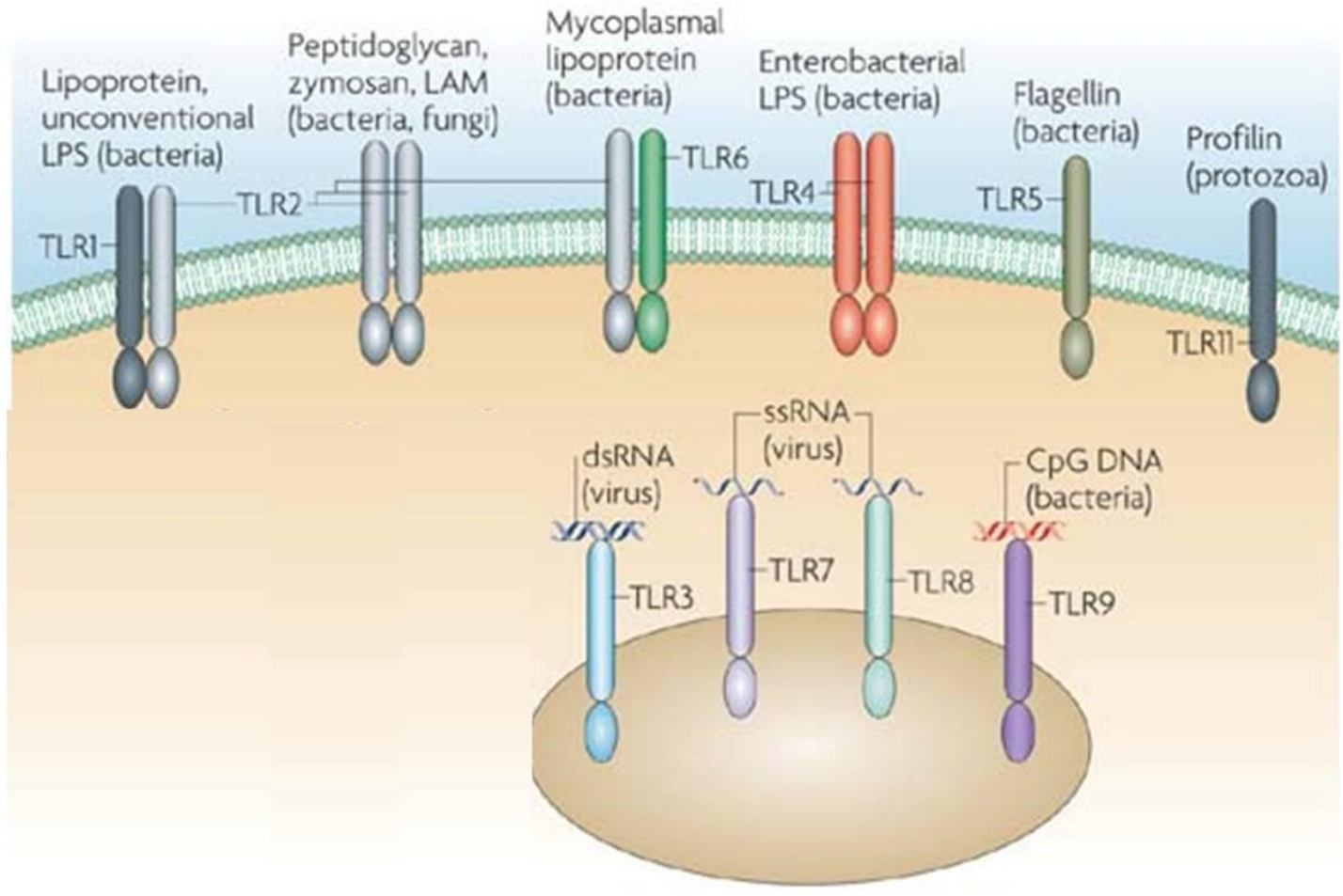

O TLR9 está localizado no retículo endoplasmático rugoso, sendo seu deslocamento para o vacúolo endossomal finamente regulado anterior a sua interação com CpG não metilado (Latz et al., 2004; El Kebir et al, 2008). Em estudo genético envolvendo N-ethyl-N-nitrosurea, Tabeta et al. (2006) identificaram uma mutação na proteína UNC93B1 em camundongos denominados “triplo D”, os quais apresentavam defeito na sinalização de TLR3, 7 e 9. Posteriormente, Brinkmann et al (2007) e Kim et al. (2008) observaram que a interação entre UNC93B1 e TLR9 é essencial para o deslocamento de TLR9 do retículo endoplasmático rugoso para o endossomo. Segundo Jong et al (2010), a habilidade de reconhecimento do receptor TLR9 se deve a sua co-localização com sequiências de DNA com repetições do 
dinucleotídeo CpG não-metilado no compartimento endolisossomal, e tal evento é dependente da ativação de proteínas da família Src.

O DNA bacteriano (procariótico) possui diferenças em relação ao DNA dos mamíferos (eucarióticos) quanto a maior frequiência do dinucleotídeo $\mathrm{CpG}$, que aparece na forma não metilada. Tal característica permite o DNA bacteriano colocalizar com TLR9 no endossomo e lhe atribui a característica de PAMP reconhecido via TLR. Segundo Krieg (2007), o DNA de seres eucarióticos possui esqueleto de fosfodiéster sendo rapidamente degradado in vivo por nucleases presentes no soro, impedindo-o de ser reconhecido por TLR9. A localização intracelular deste receptor também atua como proteção para evitar o reconhecimento do DNA próprio (Stadlbauer et al., 2008).

O DNA com seqüências $\mathrm{CpG}$, onde as citosinas aparecem na forma não metilada, reconhecido por TLR9, não é observado unicamente em células procarióticas. Bartholomeu et al (2008) demonstraram que o parasita T. cruzi possui em seu genoma seqüências ricas em motivos $\mathrm{CpG}$ as quais exercem papel imunoestimulatório em macrófagos e células dendríticas, ao potencializar a síntese de IL-12 e TNF-alfa. Ainda, de acordo com Zhang et al. (2010), as mitocôndrias são organelas evolutivamente endossimbiontes apresentando DNA com ilhas CpG não metiladas, sendo que, na ocorrência de um trauma, a lesão tecidual acarreta na liberação de tais sequiências, que ativam TLR9 e promovem a liberação de MMP-8 e IL-8 por neutrófilos via p38 MAPK.

ODNs (oligodeoxinucleotídeos) contendo motivos CpG não metilados são rapidamente internalizados por células do sistema imune, provavelmente envolvendo 
a ativação de PI3K, e interagem com TLR9 presente nas vesículas endocíticas (Takeshita et al., 2004; Duramad et al., 2005). Esta interação ocorre na dependência do baixo pH presente no endossomo e resulta no inicio da cascata de sinalização envolvendo MyD88 (myeloid differentiation primary response gene 88), IRAK (interleukine-1 receptor activated kinase) e TRAF6 (tumour-necrosis factor receptor associated factor 6 ), que culminará com ativação do fator de transcrição NFkappa-B (Akira e Takeda, 2004).

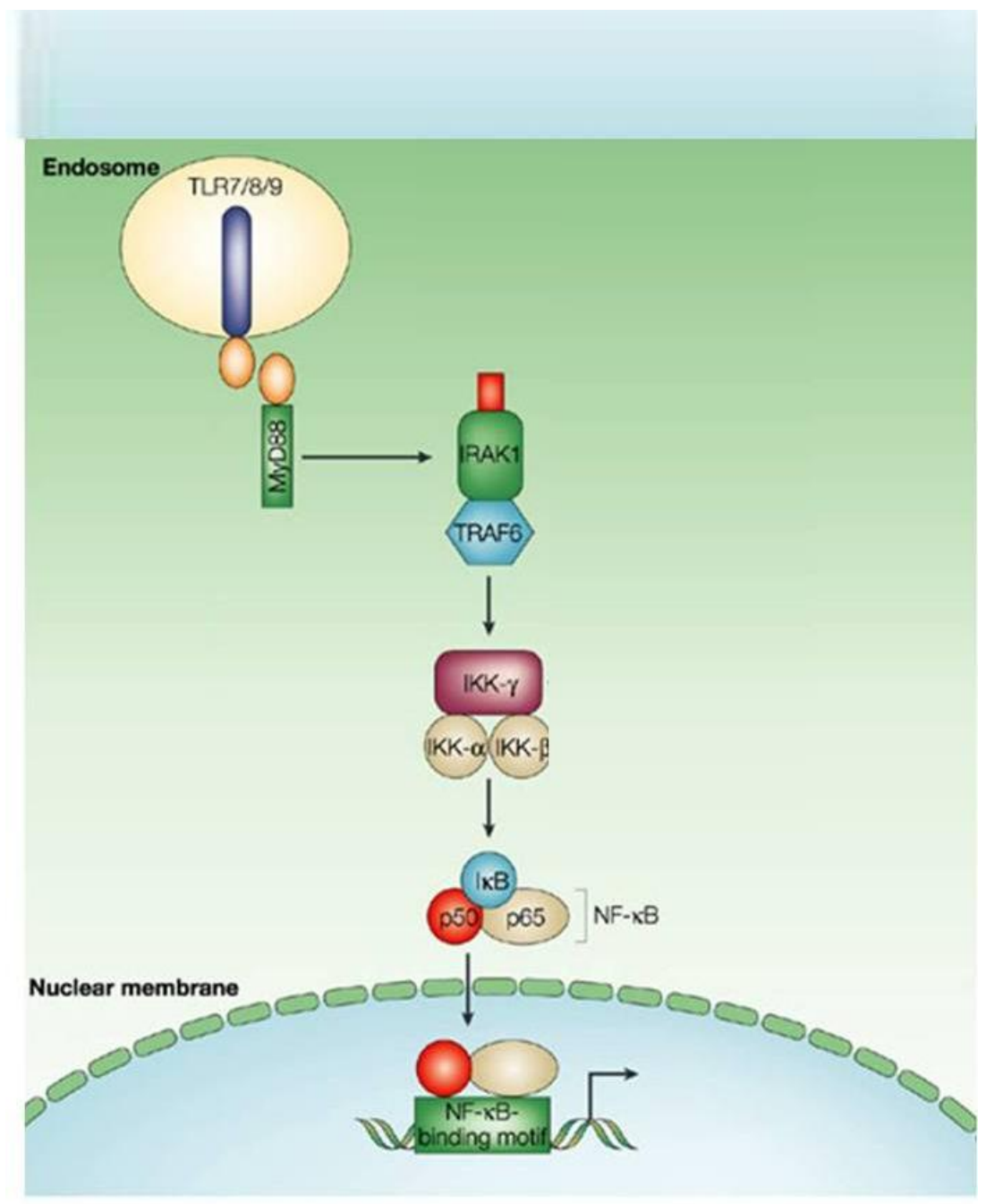

Foram descritas ao menos três classes estruturalmente distintas de oligodeoxinucleotídeos $\mathrm{CpG}$ capazes de estimular células humanas e murinas: tipos 
A (denominado também tipo $\mathrm{D}$ em humanos), $\mathrm{B}$ ( $\mathrm{K}$ em humanos) e $\mathrm{C}$. Os pertencentes ao primeiro tipo possuem esqueleto de fosfodiéster ou fosforotioato além de um único motivo hexamérico purina-pirimidina-CG-purina-pirimidina na porção 5'. O tipo $\mathrm{B}$ e tipo $\mathrm{C}$ possuem múltiplos motivos $\mathrm{CpG}$ em esqueleto de fosforotioato, sendo que o último apresenta a seqüência TCGTCG na porção 5'. Em relação à funcionalidade, ODNs tipo A atuam principalmente na maturação de células dendríticas plasmocitóides (pDCs) e secreção de IFN tipo I (IFNalfa e beta), enquanto os ODNs tipo B agem sobre a proliferação e diferenciação de células B, e os ODNs tipo C estimulam a secreção de IL-6 por células B e IFN-alfa por pDCs (Klinman, 2004). Segundo Yabuki et al (2009), o ODN CpG tipo B é uma ferramenta útil em pacientes queimados com alto risco de desenvolver infecções por potencializar a resposta inflamatória e o combate dos microrganismos, porém deve ser utilizado com cautela, pois o excesso de mediadores podem provocar choque e falência orgânica.

Células B e células pDCs são os principais tipos celulares humanos que expressam TLR9 constitutivamente e respondem diretamente a estimulação com CpG (Rothenfusser et al., 2002). A ativação de TLR9 nestas células resulta em maturação, diferenciação e proliferação de células NK (natural killer), células T e monócitos/macrófagos, que juntas secretam citocinas e quimiocinas, entre elas IL1beta, IL-6, TNF-alfa, IFN-gama e IL-12 (Klinman, 2004).

A função do TLR9 em células apresentadoras de antígeno já foi extensamente estudada, porém estas não constituem os únicos tipos celulares a expressarem o receptor (Kebir et al., 2009). Células $\mathrm{T} \mathrm{CD}^{+}$, células B, T reguladoras, neutrófilos, monócitos e células endoteliais também podem expressá-lo (Hayashi et al., 2003; 
Elmaagacli et al., 2009). Alguns estudos sugerem ainda que TLR9 tenha papel importante na proliferação e ativação de células $\mathrm{T} \mathrm{CD}^{+}$, bem como atue sobre células T reguladoras modulando sua função supressora (Chiffoleau et al., 2007).

Receptores TLR9 expressos por diferentes espécies de mamíferos também diferem quanto ao reconhecimento da seqüência dos motivos CpG. O TLR9 presente em células de camundongo difere do humano em $24 \%$ da seqüência de aminoácidos e responde melhor a ODNs CpG contendo GACGTT na seqüência, enquanto o de humano reconhece preferencialmente motivos CpG contendo GTCGTT e mais de um dinucleotídeo CG na sequiência (Rutz et al., 2004).

\subsection{Falência da migração dos neutrófilos na sepse}

A sepse pode ser definida como resposta inflamatória sistêmica frente à infecção, denotando um processo progressivo de lesão tecidual, onde a disfunção orgânica múltipla representa sua expressão mais grave (Victor et al., 2004). Esta enfermidade e suas seqüelas continuam sendo as principais causas de morbidade e mortalidade nas unidades de terapia intensiva. Estima-se que 400.000 a 500.000 pacientes desenvolvam sepse a cada ano na Europa e Estados Unidos (Macdonald et al., 2003). No Brasil, apesar de não existirem ainda estimativas precisas, a elevada incidência de sepse pôde ser observada no estudo epidemiológico BASES (Brazilian Sepsis Epidemiological Study), realizado entre 2000 e 2002, onde as incidências de sepse, sepse grave e choque séptico nos centros considerados foram de 46,9\%, 27,3\% e 23\%, respectivamente (Silva et al., 2004). Segundo o Instituto Latino Americano 
de Sepse (2008), os gastos anuais com pacientes sépticos no Brasil situam-se em $\mathrm{R} \$ 17,34$ bilhões, sendo que destes, $\mathrm{R} \$ 9,88$ bilhões são despendidos com pacientes que não sobrevivem à afecção. Portanto, a sepse possui grande significância clínica e implicações financeiras, o que atrai grande interesse científico.

A sobrevida na sepse depende de um rápido recrutamento de neutrófilos para o local primário da infecção bem como atividade microbicida destes fagócitos (Feterowski et al., 2001). A falência na migração dos neutrófilos para a cavidade peritoneal na sepse Gram-positiva e Gram-negativa resulta em permanência da infecção, bacteremia e morte (Crossara-Alberto et al., 2002; Alves- Filho et al., 2005).

O mecanismo envolvido no prejuízo da migração dos neutrófilos não foi totalmente desvendado, porém acredita-se ocorrer em função da grande liberação de citocinas pró-inflamatórias concomitante ao aumento do óxido nítrico (NO) derivado da isoforma induzida da enzima óxido nítrico sintase (Tavares- Murta et al.,1998). Benjamim et al., (2002) referem um duplo papel do NO na sepse, pois apesar de essencial como microbicida e vasodilatador, acarreta em prejuízo no recrutamento neutrofílico para o foco primário da infecção/inflamação. A falha na migração induzida pelo NO foi atribuída à redução na expressão de ICAM-1 por uma via dependente de GMPc ("guanosine 3'5'-cycle monophosphate), internalização do receptor quimiotático CXCR2 e menor formação de micropartículas contendo o ligante de P-selectina, PSGL-1 (Dal Secco et al. 2006; Rio-Santos et al., 2007; Nolan et al., 2008; Paula-Neto et al, 2010). Tendo em vista que a internalização de CXCR2 observada durante a sepse possivelmente se relaciona a maior expressão de GRK2 
(“G protein- coupled receptor kinase”) e GRK5 nos neutrófilos de pacientes sépticos (Arraes et al., 2006).

A importância dos TLRs na sepse foi demonstrada em humanos que exibiam polimorfismos nos genes que codificavam para tais receptores, bem como uso de linhagens de camundongos geneticamente modificadas (Weighardt e Holzmann, 2007). Camundongos $\mathrm{C} 3 \mathrm{H} / \mathrm{HeJ}$ possuem falha na habilidade de responder ao lipopolissacarideo (LPS) devido a uma mutação no gene que codifica para TLR4 e altera o domínio TIR. Segundo Alves-Filho et al. (2006), estes animais não apresentam falência de migração de neutrófilos para cavidade peritoneal em modelo de CLP (ligadura e perfuração do ceco), havendo menor bacteremia, menores níveis séricos de TNF-alfa, sequiestro de leucócitos no pulmão e maior sobrevida a sepse severa (S-CLP) quando comparados aos animais controles (HePas).

Alves-Filho et al. (2009) verificaram que camundongos deficientes de TLR2 apresentavam resposta semelhante aos $\mathrm{C} 3 \mathrm{H} / \mathrm{HeJ}$ a sepse severa (S-CLP), atribuindo o processo a prevenção na redução da expressão de CXCR2 e aumento de GRK2.

Adicionalmente, TLR3, cuja expressão não foi verificada em neutrófilos de humanos saudáveis por Hayashi et al. (2003), foi implicado na sepse, quando o receptor passa a ser expresso. Cavassani et al. (2008) observaram que camundongos deficientes de TLR3 apresentavam maior sobrevivência após CLP, a qual foi relacionada ao aumento de migração de neutrófilos para cavidade peritoneal, menor apoptose de neutrófilos, menor lesão orgânica e isquemia intestinal.

O TLR9 também foi implicado na evolução da sepse. Segundo Duramad et al. (2005), a sepse pode ser agravada pela ativação de TLR9, haja vista que 
camundongos pré- tratados com D-Gal apresentaram resposta inflamatória sistêmica potencializada com a adição de ODN CpG, acarretando a morte de $90 \%$ dos animais tratados com o ultimo. Ainda, Plitas et al. (2008) observaram que camundongos deficientes de TLR9 $\left(\right.$ TLR9 $^{-/}$) ou pré-tratados com inibidor de TLR9 não apresentavam falência na migração de neutrófilos para a cavidade peritoneal após CLP, havendo menor bacteremia, níveis séricos de TNF-alfa, MCP-1, IL-10, IL-6 e conseqüente maior sobrevida quando comparados aos animais selvagens. Semelhantemente, Yasuda et al. (2008) verificaram que a administração de cloroquina, inibidora da acidificação lisossomal e conseqüentemente da sinalização de TLR9, atenuou a mortalidade, declínio da função renal, apoptose esplênica e TNF-alfa sérico em camundongos submetidos a CLP. Todavia, Sjölinder et al (2008), usando modelo de sepse meningocócica, observaram que animais TLR9 ${ }^{-/}$ apresentavam menor sobrevida e maior bacteremia quando comparados aos camundongos selvagens, associando o fato a menor atividade bactericida pela menor síntese de NO in vitro pelos macrófagos peritoneais e células esplênicas, além da maior produção de citocinas como TNF-alfa e IL-6 após 24horas da inoculação intraperitoneal das bactérias. Adicionalmente, Bhan et al. (2007) também conferiram importância a ativação de TLR9 para o controle da pneumonia induzida por $K$. pneumoniae, pois camundongos deficientes do receptor apresentaram maior número de bactérias no pulmão, sangue e baço, além de menor ativação de células dendríticas, macrófagos, células Natural Killer (NK) e linfócitos T em relação aos selvagens. 
2. Objetivos 


\subsection{Objetivo Geral}

Avaliar o papel do receptor toll-like 9 na falência da migração dos neutrófilos para o foco infeccioso que ocorre na sepse, bem como verificar os mecanismos pelos quais o receptor influencia o recrutamento destes leucócitos. 


\subsection{Objetivos Específicos}

2.2.1 Avaliar se o padrão de migração de neutrófilos para o foco infeccioso primário, e conseqüente evolução da sepse, depende da expressão de TLR9. Para isso, camundongos deficientes para TLR9 $\left(\mathrm{TLR}^{-/}\right)$e C57BL/6 (selvagens) foram submetidos à ligadura e perfuração do ceco (CLP) em diferentes graus de severidade: sepse severa (S-CLP) e sepse não severa (NS-CLP), sendo os seguintes parâmetros avaliados:

a) sobrevida dos animais; b) recrutamento de neutrófilos para o foco primário da infecção; c) contagem de bactérias no local primário da infecção e no sangue; e) seqüestro de neutrófilos no pulmão; f) quimiotaxia de neutrófilos do sangue em direção a CXCL2; g) expressão de CXCR2 e indução de GRK2 em neutrófilos do sangue.

2.2.2 Verificar a expressão de TLR9 por neutrófilos circulantes de camundongo. Para isso, neutrófilos do sangue de camundongos selvagens naives e submetidos à sepse severa (S-CLP) e sepse não severa (NS-CLP) foram avaliados por meio de ensaio de citometria de fluxo para observar a presença de TLR9.

2.2.3 Verificar se a ativação sistêmica de TLR9 interfere na migração de neutrófilos para o sítio da inflamação e seqüestro destes polimorfonucleares no pulmão. Com essa finalidade, camundongos selvagens, deficientes da proteína adaptadora MyD88 (MyD88 ${ }^{-/-}$) e deficientes de TLR9 (TLR9 ${ }^{-/}$) foram tratados i.v. 
com ODN CpG e em seguida injetados i.p. com tioglicolato, sendo posteriormente avaliados:

a) migração de neutrófilos para o foco da inflamação; b) infiltração de neutrófilos no pulmão; c) quimiotaxia de neutrófilos do sangue em direção a CXCL2 (MIP-2); d) expressão de CXCR2 e indução de GRK2 em neutrófilos do sangue.

2.2.4 Verificar se a ativação de TLR9 em neutrófilos circulantes interfere diretamente na migração destes fagócitos para o foco da inflamação. Com essa finalidade foi realizado ensaio de transferência adotiva com neutrófilos provindos de camundongos selvagens marcados com CFSE e injetados em camundongos selvagens e deficientes da proteína adaptadora MyD88 (MyD88 $\left.{ }^{-/}\right)$. Em seguida, os animais foram tratados i.v. com ODN CpG e injetados i.p. com tioglicolato. Após quatro horas, foi verificado o número de neutrófilos marcados que migraram para cavidade peritoneal utilizando ensaio de citometria de fluxo.

2.2.5 Avaliar se a ativação de TLR9 em neutrófilos interfere com a quimiotaxia destes polimorfonucleares. Para isso, neutrófilos isolados da medula óssea de camundongos selvagens foram incubados com ODN CpG e submetidos a:

a) quimiotaxia em direção a CXCL2; b) polimerização de actina na presença de CXCL2; c) expressão de CXCR2; e) indução de GRK2.

2.2.6 Verificar se a ativação de TLR9 em neutrófilos interfere na função fagocitária e microbicida destes fagócitos. Para isso, neutrófilos isolados da medula óssea de camundongos selvagens foram incubados com ODN CpG e submetidos a: 
a) ensaio de fagocitose e polimerização de actina com zimosan opsonizado; b) teste de habilidade microbicida com bactérias obtidas do conteúdo cecal; c) produção de espécies reativas derivadas do oxigênio por quimioluminescência e H2DCF-DA; d) produção de óxido nítrico utilizando DAF. 
3. Material e Métodos 


\subsection{Preparo de soluções}

Meio de cultura Hank's com ou sem fenol red $(p h 7,4)$

HBSS sem cálcio e magnésio.

$9,8 \mathrm{~g}$

Água mili-Q.

$1 \mathrm{~L}$

Meio de cultura RPMI (ph 7,4)

RPMI 1640.

Hepes

$0,238 \mathrm{~g}$

Bicarbonato de sódio.

$0,220 \mathrm{~g}$

Água mili-Q. $100 \mathrm{~mL}$

Solução Tamponada fosfatada (PBS)- solução mãe $10 X(p h 7,4)$

Cloreto de sódio

$80 \mathrm{~g}$

Cloreto de potássio

$2 g$

Fosfato de potássio monobásico. $2 \mathrm{~g}$

Fosfato de sódio dibásico heptahidratado. $16,86 \mathrm{~g}$

Água mili-Q.

$1 \mathrm{~L}$ 
Solução mãe de Percoll (100\%)

Hank's concentrado 10X $5 \mathrm{~mL}$

Percoll puro $45 \mathrm{~mL}$

Solução de Percoll 65\%

Hank's 1X. $35 \mathrm{~mL}$

Percoll 100\%. $65 \mathrm{~mL}$

Solução de Percoll $72 \%$

Hank's 1X...... $28 \mathrm{~mL}$

Percoll $100 \%$ $72 \mathrm{~mL}$

Tampão de Lise a base de Cloreto de amônio $(p h 7,4)$

Cloreto de amônio. $4,01 \mathrm{~g}$

Bicarbonato de sódio $0,42 \mathrm{~g}$

EDTA dissódico. $0,18 \mathrm{~g}$ 
Anestésico a base de quetamina e xilazina

Quetamina 10\% $6 \mathrm{~mL}$

Xilazina (2,3mg.mL). $3,6 \mathrm{~mL}$

Solução de NaCL 0,9\% $50,4 \mathrm{~mL}$

Tampão de FACS

Glicose (D-glucose) $3,96 \mathrm{~g}$

Albumina sérica bovina. $5 \mathrm{~g}$

PBS $1 \mathrm{X}$ $1 \mathrm{~L}$

Tampão de permeabilização $(p h 7,4)$

Saponina. $0,5 \mathrm{~g}$

Albumina sérica bovina. $0,5 \mathrm{~g}$

PBS $1 X$ $100 \mathrm{~mL}$

Tampão de fixação

Formaldeído 37\% $10 \mathrm{~mL}$

PBS 1X. $90 \mathrm{~mL}$ 
Meio de cultivo para bactérias Ágar Müller Hilton

Ágar Müller Hilton $30,4 \mathrm{~g}$

Água mili-Q. $800 \mathrm{~mL}$

Meio de cultivo para bactérias BHI (Brain Heart Infusion)

BHI $30,4 \mathrm{~g}$

Água mili-Q. $800 \mathrm{~mL}$

\subsection{Oligodeoxinucleotídeos e anticorpos}

O ODN CpG 297 de T.cruzi tipo B (5'- TCCTCGTTTTGACGTG- 3') foi gentilmente cedido pelo Prof. Ricardo T. Gazzinelli (Universidade Federal Minas Gerais - Brasil). O ODN controle (5'-GGGGTCAAGCTTGAGGGGGG-3') foi sintetizado em esqueleto de fosforotioato pela Alpha DNA (Montreal, Canadá). O anticorpo monoclonal GRK2 foi adquirido da Santa Cruz Biotecnology (Santa Cruz, USA) e seu respectivo secundário conjugado a Alexa Fuor 594 da Invitrogen (Oregon, USA). O anticorpo anti-mouse CXCR2 mAb PE proveio da R\&D Systems (USA), o anti TLR9 mAb FITC da eBiosiences (USA), o anti-Gr1 mAb PercP e antiF4/80 PE mAb da BD Biosciences (Franklin Lakes, USA). 


\subsection{Animais}

Utilizaram-se camundongos C57BL/6 (selvagens) provenientes do Biotério Central da Faculdade de Medicina de Ribeirão Preto (FMRP-USP). Os camundongos

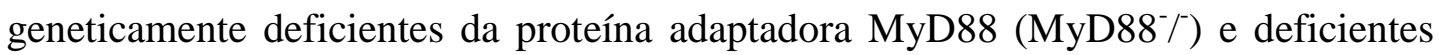
para o receptor Toll-Like 9 (TLR9\%) provieram do Biotério de Criação do Departamento de Genética da FMRP-USP. Os camundongos utilizados possuíam entre seis e 10 semanas de idade, pesavam aproximadamente $25 \mathrm{~g}$, e foram mantidos no biotério de criação do Departamento de Farmacologia da FMRP-USP, sob condições de temperatura $\left(23-25{ }^{\circ} \mathrm{C}\right)$ e ciclo claro/escuro (12 horas) controlados, com água e ração ad libitum.

Todos os protocolos experimentais realizados neste trabalho foram conduzidos de acordo com os Princípios Éticos de Experimentação Animal, adotado pelo Colégio Brasileiro de Experimentação Animal (COBEA), e avaliado pela Comissão de Ética em Experimentação Animal (CETEA) da FMRP-USP (protocolo $\left.n^{\circ} 150 / 2009\right)$.

\subsection{Modelo de sepse - Ligadura e perfuração do ceco (CLP)}

Como modelo de sepse polimicrobiana não severa (NS) e severa (S) foi utilizada a ligadura e perfuração do ceco (CLP) proposta por Benjamin et al. (2002) e modificada por Alves-Filho et al. (2006). Os camundongos foram anestesiados com 
quetamina $(100 \mathrm{mg} / \mathrm{kg})$ e xilazina $(15 \mathrm{mg} / \mathrm{kg})$. Após celiotomia mediana com incisão de aproximadamente $1 \mathrm{~cm}$, o ceco foi exposto e ligado com fio de algodão 4-0 na altura da válvula íleo-cecocólica. Para a NS-CLP foram realizadas três perfurações com agulha $0,30 X 13 \mathrm{~mm}(30 \mathrm{G})$ na extremidade do ceco e para S-CLP, o mesmo foi transfixado com agulha 1,2X40mm (18G), pressionando-se o órgão para saída das fezes. O ceco foi devolvido a cavidade peritoneal e realizada laparorrafia com fio de algodão 4-0. Todos os animais foram injetados com $1 \mathrm{~mL}$ de solução de cloreto de sódio $0,9 \%$ subcutâneo após a cirurgia e mantidos aquecidos durante a recuperação da anestesia. Os animais sham ou falso operados (controles) foram submetidos ao mesmo procedimento, porém sem as perfurações no ceco.

\subsection{Migração de neutrófilos para o foco de inflamação/infecção}

Após seis horas da indução da sepse ou quatro horas após a injeção de $300 \mu \mathrm{L}$ tioglicolato $3 \%$ i.p., os animais foram eutanasiados e realizado lavado peritoneal com $3 \mathrm{~mL}$ de solução salina tamponada fosfatada (PBS) acrescida de EDTA 1mM. A contagem total de leucócitos foi feita em contador automático (Coulter ${ }^{\circledR} \mathrm{A}^{\mathrm{c}} \mathrm{T}$; Coulter Corporation, Miami, Florida, USA.) e expressa como número de $10^{6}$ células $/ \mathrm{mL}$. A contagem diferencial foi realizada com 100 células a partir do lavado preparado em citocentrífuga (Coulter ${ }^{\circledR} \mathrm{A}^{\mathrm{c}} \mathrm{T}$; Coulter Corporation, Miami, Florida, USA) e corado pelo método de May Grunwald Giemsa (Panótico rápido corante para uso hematológico, Laborclin ltda, Pinhais-SP, Brasil). Os resultados 
foram expressos como número de neutrófilos presentes no lavado peritoneal $\mathrm{x}$ $10^{6} \%$ cavidade.

\subsection{Microscopia Intravital}

Cada camundongo foi anestesiado com solução de quetamina $(100 \mathrm{mg} / \mathrm{kg}) / x$ ilazina $(15 \mathrm{mg} / \mathrm{kg})$ e colocado sobre mesa cirúrgica aquecida $37^{\circ} \mathrm{C}$ acoplada ao microscópio. Foi realizada celiotomia e o mesentério exposto. Os vasos foram focalizados (40X) selecionando-se vênula de diâmetro $(10-18 \mu \mathrm{m})$ que pudesse favorecer a visualização do rolamento dos leucócitos e aderência (células fixas ao endotélio) durante cinco minutos. Os resultados foram expressos em número de leucócitos aderidos por $10 \mu \mathrm{m}^{2}$ da vênula e número de leucócitos em rolamento/minuto.

\subsection{Quantificação bacteriana}

O lavado peritoneal e o sangue heparinizado $(10 \mathrm{U} / \mathrm{mL})$ foram semeados (dez microlitros), sob condições estéreis, em placas de Petri contendo Ágar Müeller Hinton (Difco Laboratories, Detroit, USA). As placas de cultura foram incubadas por 18 horas a $37{ }^{\circ} \mathrm{C}$ e o número de unidades formadoras de colônia (UFC) quantificado manualmente. Os resultados foram expressos como $\log$ de UFC/mL do lavado peritoneal e do sangue. 


\subsection{Dosagens de citocinas}

A quantificação das citocinas no soro e lavado peritoneal foi realizada seis horas após a sepse. Para obtenção do soro, o sangue foi centrifugado a $4^{\circ} \mathrm{C}, 600 \mathrm{~g}$ durante 10 minutos. As dosagens de TNF-alfa, MIP-2 e KC foram feitas pelo método imunoenzimático (ELISA). Em resumo, placas de 96 poços foram cobertas com 50 $\mu \mathrm{L} /$ poço dos anticorpos específicos para cada citocina (Pharmigen, San Diego, CA, USA.). Estes anticorpos foram diluídos em solução de ligação pH 9,0 e incubados por 18-24 horas, a $4^{\circ} \mathrm{C}$. As placas então foram lavadas por três vezes com PBS/Tween-20 (0,05\% Sigma). As ligações não específicas foram bloqueadas com $100 \mu \mathrm{L}$ de PBS/BSA $1 \%$ por 120 minutos em temperatura ambiente. As amostras e o padrão (curva padrão) contendo as concentrações para as citocinas foram colocados nas placas $(50 \mu \mathrm{L})$ e incubados por $18-24$ horas a $4^{\circ} \mathrm{C}$. Após esse período, as placas foram lavadas comPBS/Tween e $50 \mu \mathrm{L}$ dos anticorpos biotinilados específicos para cada citocina foram adicionados. Após uma hora, as placas foram lavadas com PSB/Tween e o conjugado avidina-peroxidase, na diluição de 1/5000, adicionado a cada poço. Após 30 minutos de incubação, as placas foram lavadas com PBS/Tween e $100 \mu \mathrm{L}$ do substrato OPD (o-fenilenediaminadihidrocloreto; Sigma.). As placas então foram incubadas por 15 a 20 minutos em temperatura ambiente. A reação foi interrompida com $50 \mu \mathrm{L}$ de $\mathrm{H}_{2} \mathrm{SO}_{4}(1 \mathrm{M})$ e a densidade óptica medida a 490nm em espectrofotômetro (Spectra Max-250, Molecular Devices.). Os resultados foram expressos em picogramas/mL. 


\subsection{Mensuração dos neutrófilos no tecido pulmonar}

A quantificação do seqüestro de neutrófilos no pulmão foi inferida pelo ensaio de mieloperoxidase (MPO). Resumidamente, após eutanásia, os animais foram perfundidos com PBS, o lobo pulmonar inferior esquerdo coletado e imerso em $200 \mu \mathrm{L}$ de solução tampão $\left(\mathrm{NaCl}\right.$ 0,1M; $\mathrm{NaPO}_{4}$ 0,02M; NaEDTA 0,012M; pH 4,7). O parênquima foi triturado com auxílio de homogeneizador de tecido (Polytron ${ }^{\circledR}$, Polyron PT 3100, USA) em13000 rpm, as hemácias lisadas em solução de $\mathrm{NaCl}$ a $0,2 \%$ e os leucócitos em solução $\mathrm{NaPO}_{4}$ 0,05M com H-TaB 0,5\%. A reação da mieloperoxidase procedeu-se pela adição de peróxido de hidrogênio $(0,5 \mathrm{mM})$ e revelada com TMB 3,845mg/mL. A absorbância foi medida a 450nm em espectrofotômetro (Spectra Max-250, Molecular Devices) e os resultados expressos em número de neutrófilos/mg de tecido.

A absorbância das amostras foi correlacionada com o número de neutrófilos a partir de curva pré-estabelecida. Para obtenção da curva de neutrófilos, camundongos foram injetados i.p. com $500 \mu$ g de carregenina ( $1 \mathrm{~mL} / \mathrm{animal})$ e após quatro horas realizado lavado peritoneal com PBS/EDTA $1 \mathrm{mM}$. As hemácias foram lisadas com tampão a base de cloreto de sódio $0,2 \%$ e avaliada a pureza dos neutrófilos em lâmina realizada em citocentrífuga. Foram consideradas somente amostras com pureza acima de 90\% de neutrófilos. Após a determinação do número de leucócitos em contador automático, estes foram lisados em solução $\mathrm{NaPO}_{4}$ 0,05M com H-TaB $0,5 \%$ e aliquotados em tubos plásticos $\left(2 \times 10^{6}\right.$ neutrófilos $\left./ \mathrm{mL}\right)$. 


\subsection{Isolamento de neutrófilos do sangue e medula óssea}

Os neutrófilos do sangue ou medula óssea foram obtidos por meio de separação em gradiente constituído por soluções a 72 e $65 \%$ de Percoll (Percoll, Fiuka Biochemica, Sigma-Aldrich ${ }^{\circledR}$, Steinheim, Sweden.), 2mL cada. Em resumo, dois mililitros do sangue ou lavado do canal medular (fêmur e tíbia) com meio Hank's foram colocados sobre o gradiente de Percoll e centrifugados $1200 \mathrm{~g}$, a $20^{\circ} \mathrm{C}$, com $2 \mathrm{~m} / \mathrm{s}^{2}$ de aceleração e desaceleração, durante 32 minutos. A camada de mononucleares, sobre a solução a $65 \%$, foi descartada e a camada de polimorfonucleares, sobre a solução a $72 \%$ foi colocada em tubo plástico estéril de 15mL. As hemácias contidas entre os polimorfonucleares foram lisadas com tampão de $\mathrm{NH}_{4} \mathrm{Cl} 4 \%$ e as células lavadas com meio Hank's. O número de células após o isolamento foi obtido em contador automático, a pureza em neutrófilos feita a partir de análise em lâmina pela contagem de 100 células e a viabilidade por exclusão do azul de Tripan 1\% (1:1). Apenas as amostras com pureza acima de $80 \%$ e viabilidade acima de $90 \%$ foram consideradas nos ensaios.

\subsection{Quimiotaxia de neutrófilos}

A quimiotaxia foi realizada em câmara de 48 poços (Câmara de Boyden, Neuro Probe Inc., Cabin John, USA) com membrana de policarbonato (Filtro de policabonato $5 \mu \mathrm{m}$, Neuroprobe, Pleasanton, CA, USA.) conforme preconizado por 
Arraes et al. (2006). Os neutrófilos isolados do sangue ou da medula óssea de camundongos ( 1 x $10^{6}$ células/mL) migraram em direção a quimiocina CXCL2 ou CXCL1 (30ng/mL). Como controle negativo utilizou-se meio RPMI (RPMI-1640 medium, Sigma-Culture ${ }^{\circledR}$, St. Louis, USA) acrescido de albumina sérica bovina (BSA) $0,01 \%$. Após uma hora de incubação em estufa a $37^{\circ} \mathrm{C}$ e $5 \%$ de $\mathrm{CO}_{2}$, as células contidas na membrana foram fixadas e coradas (Instant-prov, Newprov, Pinhais-PR, Brasil). Em seguida, os neutrófilos foram contados em microscópio óptico (1000X com lente de imersão em óleo) abrangendo aleatoriamente cinco campos por poço. $\mathrm{O}$ experimento foi realizado em quadruplicata e os resultados expressos em número de neutrófilos/campo.

\subsection{Expressão de GRK2}

A expressão da proteína GRK2 foi realizada por imunofluorescência. Em resumo, os neutrófilos isolados do sangue ou da medula óssea de camundongos (50.000) foram fixados em lâmina com paraformaldeído 4\%, tratados com Triton X100 a $0,2 \%$, bloqueados com soro de cabra e incubados com anticorpo primário antiGRK2 feito em coelho (1:200). Após 12 horas, as células foram lavadas em PBS e incubadas com composto fluorescente Alexa Flúor 594 anti-coelho feito em cabra (1:400). O material genético dos neutrófilos foi marcado com 4, 6-diamidino-2fenilindol (DAPI) 1mM para otimizar a leitura. 
As imagens das células marcadas foram adquiridas utilizando-se microscópio de epifluorescência (BX-40; Olympus, Japan) em aumento de 400X. Todas as imagens foram captadas com câmera em configurações idênticas: tempo de exposição, brilho, contraste e nitidez, de acordo com a fluorescência e filtro apropriado utilizando o software Image-Pro Plus 4,0 (Media Cybernetics).

\subsection{Polimerização de actina}

Para verificar a polimerização de actina, os neutrófilos isolados da medula óssea foram estimulados com CXCL2 (30ng/mL) por 1 minuto ou zimosan opsonizado (5 partículas/célula) em diferentes períodos de tempo. Em seguida, os neutrófilos foram fixados com paraformaldeído 4\%. As células foram permeabilizadas com Triton X-100 $0.2 \%$ e incubadas com faloidina conjugada a rodamina (Sigma, St Louis, MO). O material genético dos neutrófilos foi marcado com 4, 6-diamidino-2-fenilindol (DAPI) 1mM para otimizar a leitura.

As imagens das células marcadas foram adquiridas utilizando-se microscópio de epifluorescência (BX-40; Olympus, Japan) em aumento de 400X. Todas as imagens foram captadas com câmera em configurações idênticas: tempo de exposição, brilho, contraste e nitidez, de acordo com a fluorescência e filtro apropriado utilizando o software Image-Pro Plus 4,0 (Media Cybernetics). A 
Intensidade Média de Fluorescência (I.M.F.) foi determinada a partir do software Image-J ${ }^{\circledR}$ (National Institute of Health - NIH, Bethesda, EUA).

\subsection{Ensaio de "Killing”}

Para verificar a capacidade bactericida (“Killing”), neutrófilos (1 x $10^{6}$ células/mL) foram incubados com bactérias do conteúdo cecal $\left(2 \times 10^{6}\right.$ bactérias $\left./ \mathrm{mL}\right)$ durante duas horas a $37^{\circ} \mathrm{C}$. Em seguida, as células foram lisadas com 500 microlitros de Triton X-100 0,2\%, sonicadas por dois minutos e mantidas em temperatura ambiente por 15 minutos. Dez microlitros do meio de incubação foram semeados sobre Ágar Müller Hinton e incubados a $37^{\circ} \mathrm{C}$. As unidades formadoras de colônia (UFC) foram analisadas após 18 horas, e os resultados expressos como $10^{5} \mathrm{UFC} / \mathrm{mL}$.

Para a obtenção das bactérias do conteúdo cecal, o mesmo foi retirado de camundongo selvagem naive e dissolvido em $5 \mathrm{~mL}$ de PBS estéril. Após filtragem em gaze estéril, as fezes foram cultivadas em meio BHI durante cinco dias, trocando-se o meio a cada 24 horas. Ao final do quinto dia, as bactérias foram dissolvidas em $10 \mathrm{~mL}$ e liofilizadas $(55 \mu \mathrm{L} / \mathrm{tubo})$. Antes do uso, as bactérias de cada tubo foram cultivadas em 50mL de BHI durante 20 horas, lavadas com PBS estéril (3000g, 10 minutos), opsonizadas com soro de camundongo (10\%), lavadas novamente em PBS estéril, ressuspensas em 10mL de PBS e este diluído 1:100 (uso de $22 \mu \mathrm{L}$ equivalente a $2 \times 10^{6}$ bactérias). 


\subsection{Ensaio de fagocitose}

Para verificar a capacidade fagocitária dos neutrófilos foi realizado ensaio de fagocitose com zimosan opsonizado. Em resumo, neutrófilos (1x $10^{6}$ células) foram incubados com $5 \times 10^{6}$ partículas de zimosan opsonizado em $1 \mathrm{~mL}$ de meio RPMI por 30 minutos. Após a incubação, os neutrófilos foram lavados com PBS e centrifugados três vezes a $400 \mathrm{~g}$. Em seguida, as células foram ressuspensas em PBS, fixadas em lâminas e coradas pelo método de May Grunwald Giemsa. A fagocitose dos neutrófilos foi quantificada a partir da contagem de 100 células.

\subsection{Citometria de fluxo (FACSAria ${ }^{\mathrm{TM}}$ )}

\subsubsection{Expressão de CXCR2}

Para verificar a expressão do receptor quimiotático CXCR2 utilizou-se anticorpos monoclonais anti-Gr1 (1:200) e anti-CXCR2 (1:50) marcados com PerCP e PE, respectivamente. Quando utilizados neutrófilos isolados da medula óssea $\left(3 \times 10^{5}\right.$ células), foi realizado bloqueio de 30 minutos com soro de cabra antes da incubação com os anticorpos. Nas amostras onde se utilizou sangue total, após a incubação durante 30 minutos a $4^{\circ} \mathrm{C}$ com os anticorpos, as hemácias foram lisadas com tampão a base de cloreto de amônio. 


\subsubsection{Expressão de TLR9}

Para identificação de TLR9 nos neutrófilos em sangue total, inicialmente, estes foram marcados com anti-Gr1 PercP (1:200), antiF4/80 PE (1:200) e as hemácias lisadas com tampão de $\mathrm{NH}_{4} \mathrm{CL} 4 \%$. Em seguida, os leucócitos foram fixados com formaldeído $4 \%$, permeabilizados com tampão de saponina acrescido de BSA e marcados com anti-TLR9 FITC (1:100).

\subsubsection{Determinação da produção de peróxido de hidrogênio}

Para a determinação da produção de $\mathrm{H}_{2} \mathrm{O}_{2}$ utilizou-se $\mathrm{H}$ 2DCF-DA $(2,7$ dichlorofluorecein diacetate, Biotium, Inc. Hyward, CA, USA/ PM: 487,29) em sangue total, fazendo uso dos anticorpos monoclonais anti-Gr1 (1:200), anti-F4/80 (1:200) conjugados com PerCP (Peridinin Chlorophyll Protein Complex) e PE (Phycoerythrin), respectivamente. Em resumo, 100 $\mu 1$ de sangue foram incubados com H2DCFDA (60 $\mu \mathrm{M}$ diluído em PBS - Solução estoque $25 \mathrm{mM}$ em etanol P.A.) em Banho-Maria a $37^{\circ} \mathrm{C}$ sob agitação durante 30minutos. Em seguida, as amostras foram centrifugadas a 500g durante 10 minutos com $2 \mathrm{~mL}$ de solução de EDTA $3 \mathrm{mM}$ e marcadas com os anticorpos e respectivos isotipos ( PE IgG2a e PercP IgG2a) durante 30 minutos. As amostras foram lavadas com PBS e adquiridas em citometro de fluxo. 


\subsubsection{Viabilidade dos neutrófilos}

Para verificar a viabilidade de neutrófilos incubados com ODN CpG utilizou-se ensaio com anexina (FITC Annexin V Apoptosis Detection Kit I, BD Pharmigen, USA) e PI (Iodeto de propidio, Abcam, USA) em tampão de anexina (1:10) diluído em PBS.

\subsubsection{Fenotipagem das células do lavado peritoneal e pulmão}

Para a determinação dos tipos celulares presentes no lavado peritoneal e pulmão foi realizada marcação com anticorpos anti-Gr1 (1:200), anti-F4/80 (1:200) e anti-CD11c (1:200). Para o processamento do pulmão utilizou-se triturador (Medcon, Becton Dickinson, São José, CA-USA) em aparelho automatizado (Medmachine, Becton, Dickinson, São José, CA-USA). Para facilitar a separação das células que compõe o tecido, o pulmão foi incubado 30 minutos com a enzima liberase (Liberase Blendzyme CC-Roche LTDA, Suiça, na concentração 1:100) ,e após o processamento as amostras foram filtradas (Filcons, Becton, Dickinson, São José, CA-USA) para remoção dos debris e tecido fibroso.

Todas as amostras foram adquiridas em FACSAria ${ }^{\mathrm{TM}}$ (BD Immunocytometry System, Franklin Lakes, USA), permitindo analisar todas as células (50.000 eventos/amostra) ou apenas determinadas populações, individualizadas por janelas 
(ou "Gates") estabelecidas com base em parâmetros de tamanho e complexidade ou fluorescência. As análises foram realizadas utilizando o software Flowjo 7.5.5 (Flow Cytometry analisis software, Tree Star Inc., San Carlos, CA, USA). A mediana e média da intensidade de fluorescência para CXCR2, DAF e DCF foram obtidas de população $\mathrm{Gr} 1^{\text {high }}$ ou $\mathrm{Gr} 1^{+} \mathrm{F} 4 / 80^{-}$.

Em geral as análises foram realizadas seguindo mesmo padrão. Inicialmente, em tubo contendo células não marcadas optou-se por um gráfico de pontos (“Dot Plot”) cruzando as variáveis área (FSC-A) e altura das células (FSC-H) para definir uma população que exclui debris celulares e grumos de células adquiridas como único evento. Após definir a primeira população, dentro desta, optou-se por um gráfico de pontos ("Dot Plot”) cruzando as variáveis: tamanho (FSC-A) e complexidade (SSC-A), onde foi estabelecida população característica de neutrófilos. Depois de definidas, a primeira e segunda população foram "extendidas" para todos os tubos. Nos tubos contendo anticorpos marcados com fluorocromos, dentro da segunda população e com base no isotipo controle, utilizando gráficos de pontos (“Dot Plot”) cruzando as variáveis tamanho (FSC-A) e fluorescência, determinou-se a população marcada, bem como a mediana e a média de intensidade de fluorescência do alvo na dada população. 

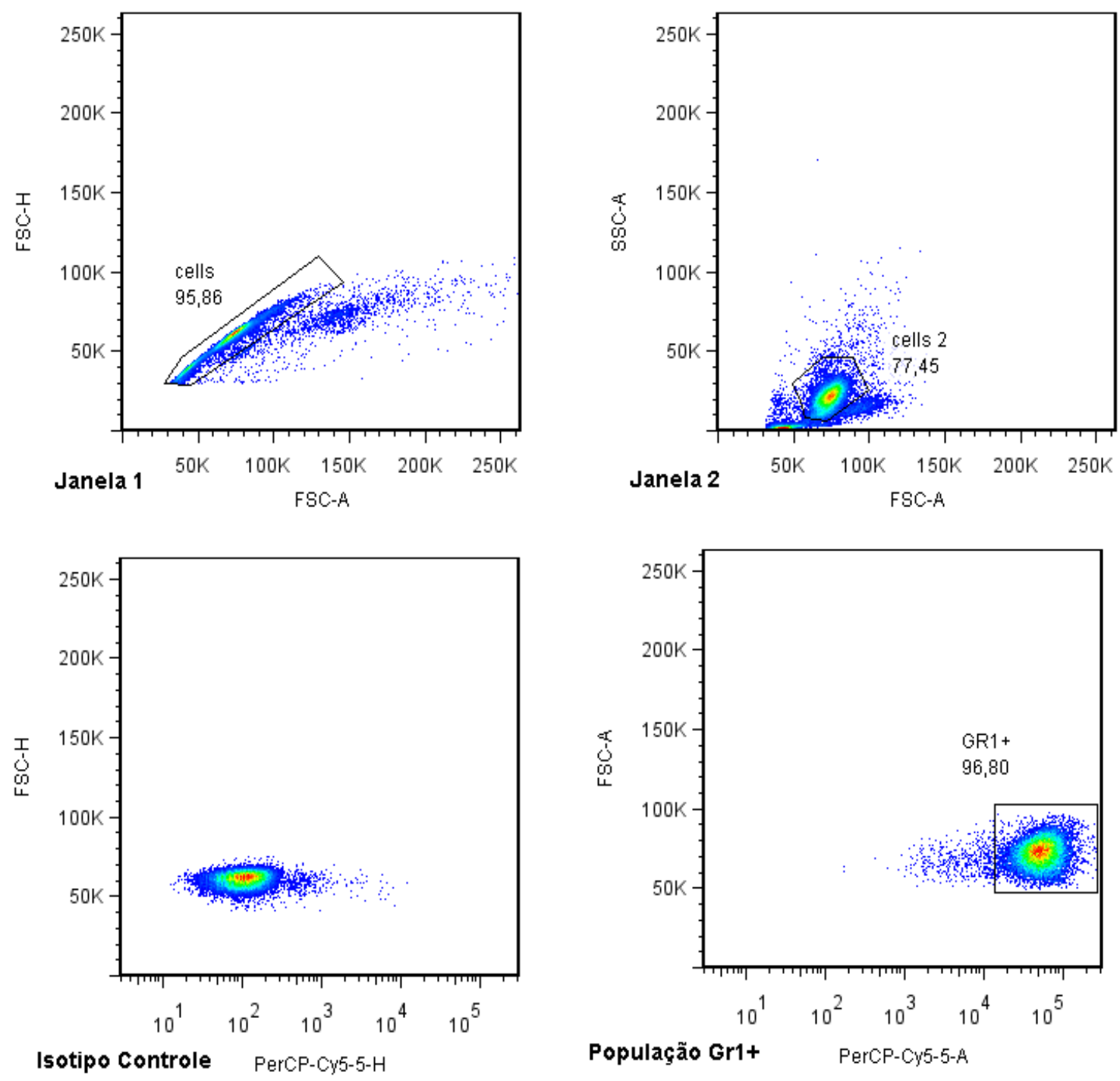

\subsection{Ensaio de transferência adotiva}

Para o ensaio de transferência, neutrófilos isolados da medula óssea de camundongos selvagens foram marcados com Carboxyfluorescein succinimidyl Ester/CFSE $(0,5 \mu \mathrm{M})$ durante 15 minutos. As células marcadas foram injetadas 
$\left(3 \times 10^{6}\right.$ células/animal) i.v. em camundongos selvagens e deficientes da proteína adaptadora MyD88. Após 30 minutos, todos os animais receberam tratamento com ODN CpG $(0.9 \mathrm{mg} / \mathrm{Kg})$ i.v. ou PBS e tioglicolato $3 \%(200 \mu \mathrm{L} / \mathrm{animal})$ foi injetado intraperitonealmente. Depois de quatro horas, os animais foram eutanasiados para realização do lavado peritoneal e o exudato adquirido em citômetro de fluxo (BD Immunocytometry System, Franklin Lakes, USA). Os resultados foram expressos em neutrófilos $\mathrm{CFSE}^{+} / 10^{6}$ eventos.

\subsection{Produção de óxido nítrico (NO)}

Para a determinação da produção de óxido nítrico utilizou-se DAF (4,5diamino-fluoresceína, Invitrogen, USA) em neutrófilos isolados da medula óssea, fazendo uso dos anticorpos monoclonais anti-Gr1 (1:200), anti-F4/80 (1:200) conjugados com PerCP (Peridinin Chlorophyll Protein Complex) e PE (Phycoerythrin), respectivamente. Em resumo, os neutrófilos foram incubados com DAF $(10 \mu \mathrm{M})$ diluído em Hanks' sem fenol acrescido de L-NG-nitro-Arginina (100 $\mu \mathrm{M}$, Sigma) em Banho-Maria a $37^{\circ} \mathrm{C}$ sob agitação durante 30 minutos. Em seguida, as amostras foram centrifugadas a $500 \mathrm{~g}$ durante 10 minutos com $2 \mathrm{~mL}$ de solução de Hanks' sem fenol acrescido de L-Arginina (100 $\mu \mathrm{M}$, Sigma) e incubadas com ODN CpG. Após duas horas, as células foram marcadas com os anticorpos e respectivos isotipos ( $\mathrm{PE} \operatorname{IgG} 2 \mathrm{a}$ e PercP IgG2a) durante 30 minutos. As amostras foram lavadas com PBS e adquiridas em FACSAria ${ }^{\mathrm{TM}}$ (BD Immunocytometry 
System, Franklin Lakes, USA). As análises foram realizadas utilizando o software Flowjo 7.5.5 (Flow Cytometry analisis software, Tree Star Inc., San Carlos, CA, USA). A mediana da intensidade de fluorescência para o DAF foi obtida de população $\mathrm{Gr}^{+}{ }^{+} / \mathrm{F} 4 / 80^{-}$a partir de 50.000 eventos.

\subsection{Produção de superóxido}

A produção de superóxido pelos neutrófilos foi avaliada por quimioluminescência (Photomultiplier ET Enterprises electron tubes, ET Enterprises Limited, England) utilizando lucigenina $(20 \mu \mathrm{M})$. Em resumo, 0,5 x $10^{6}$ neutrófilos isolados da medula óssea foram incubados com ODN CpG em meio Hank's sem fenol durante duas horas e colocados sobre placas de vidro siliconizadas juntamente com lucigenina, sendo a produção de superóxido avaliada a $37^{\circ} \mathrm{C}$ durante 10 minutos. Os resultados foram expressos em unidades arbitrárias como contagens/segundo.

\section{20 Delineamentos experimentais}

3.20.1 Evolução da sepse em camundongos deficientes de TLR9

Os camundongos selvagens $(n=15)$ e TLR9 $^{-/-}(n=15)$ submetidos à ligadura e perfuração do ceco, severa (S-CLP) e não severa (NS-CLP) tiveram a sobrevida avaliada a cada 24 horas durante sete dias consecutivos. 
Seis horas depois da CLP, os animais $(n=5)$ foram eutanasiados sendo efetuados: lavagem da cavidade peritoneal, retirada de sangue por punção cardíaca, retirada do pulmão. Em seguida foram avaliados: migração de neutrófilos para a cavidade peritoneal por meio da contagem total e diferencial de leucócitos, bem como ensaio de citometria de fluxo no lavado peritoneal; seqüestro de neutrófilos no parênquima pulmonar por meio de ensaio de mieloperoxidase e citometria de fluxo; quantificação bacteriana no lavado peritoneal e no sangue.

Duas horas após CLP, os animais $(\mathrm{n}=5)$ foram eutanasiados sendo retirado o sangue por punção cardíaca e avaliados: expressão de CXCR2 em neutrófilos (população Gr1 ${ }^{\text {high }}$ ) por citometria de fluxo; indução de GRK2 por imunofluorescência em neutrófilos isolados; e quimiotaxia de neutrófilos isolados em direção a CXCL2 utilizando câmara de Boyden modificada.

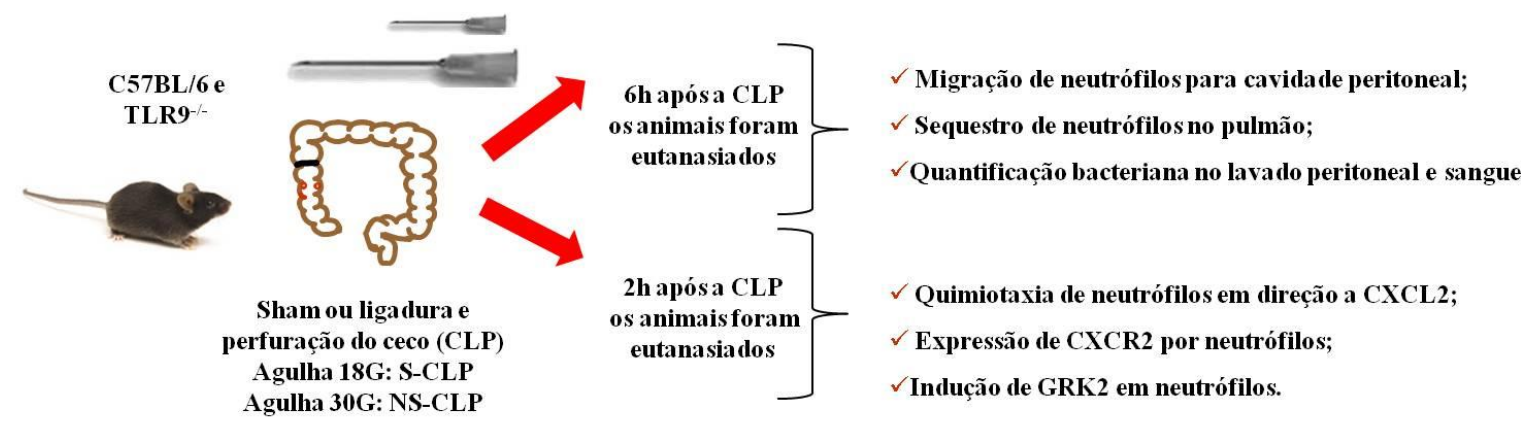

$\checkmark$ Sobrevida ( 7 dias) 


\subsubsection{Migração dos neutrófilos após ativação sistêmica de TLR9}

Camundongos selvagens $(n=5)$, deficientes $(n=5)$ da proteína adaptadora MyD88 (MyD88 ${ }^{-/}$) ou deficientes $(\mathrm{n}=5)$ de TLR9 $\left(\right.$ TLR9 $\left.^{-/}\right)$foram tratados i.v. com ODN CpG $(0,9 \mathrm{mg} / \mathrm{Kg})$, e depois de 30 minutos, injetados i.p. com $200 \mu \mathrm{l}$ de tioglicolato 3\%. Após quatro horas da injeção de tioglicolato os animais foram eutanasiados e efetuados: lavagem da cavidade peritoneal, retirada do sangue por punção cardíaca e remoção do pulmão. Em seguida foram avaliados: migração de neutrófilos para o foco da inflamação por meio da contagem total e diferencial de leucócitos no lavado peritoneal; infiltração de neutrófilos no pulmão por meio do ensaio de mieloperoxidase.

Duas horas depois do tratamento i.v. com ODN CpG $(0,9 \mathrm{mg} / \mathrm{Kg})$, os animais $(n=5)$ foram eutanasiados sendo retirado o sangue por punção cardíaca e avaliados: expressão de CXCR2 em neutrófilos (população $\mathrm{Gr} 1^{\text {high }}$ ) por citometria de fluxo; indução de GRK2 por imunofluorescência em neutrófilos isolados; e quimiotaxia de neutrófilos isolados em direção a CXCL2 e CXCL1 utilizando câmara de Boyden modificada. 


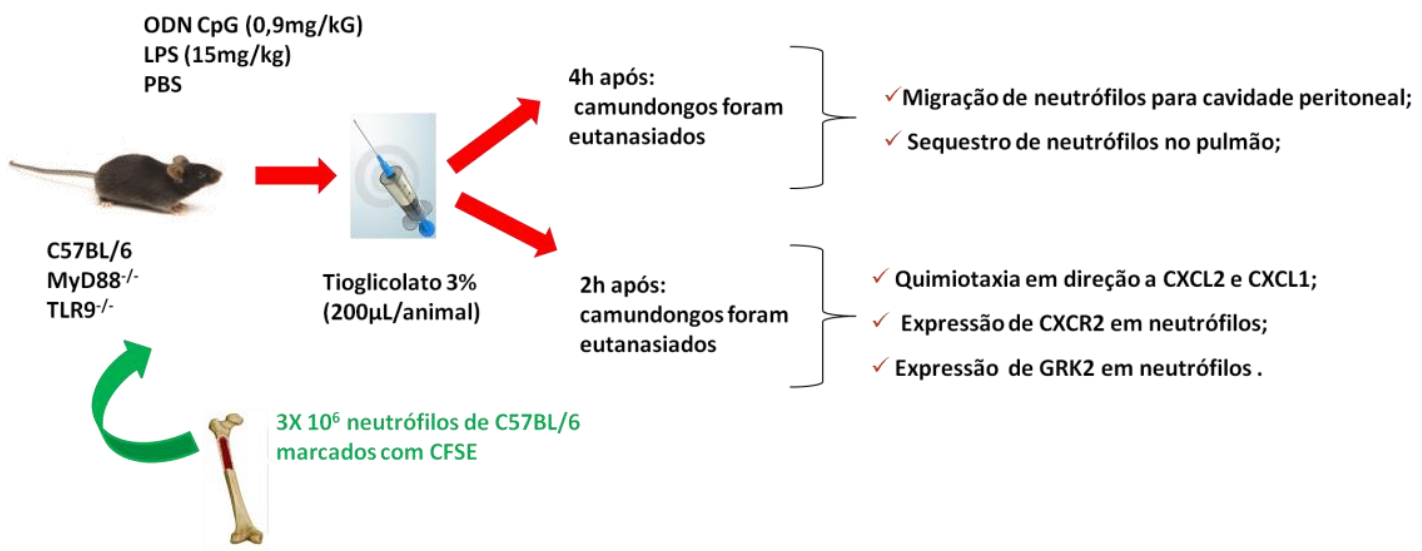

3.20.3 Funções dos neutrófilos após ativação de TLR9

Neutrófilos isolados da medula óssea de camundongos selvagens, MyD88 ${ }^{-/-} \mathrm{e}$ TLR9 $^{-/-}$foram incubados durante uma hora com diferentes concentrações de ODN CpG $(0,3$ a 100 $\mu \mathrm{g} / \mathrm{ml})$ e submetidos a quimiotaxia em direção a CXCL2 (30ng/mL) utilizando câmara de Boyden modificada. Adicionalmente, neutrófilos isolados da medula óssea também foram incubados durante duas horas com ODN CpG na concentração $0,3 \mu \mathrm{g} / \mathrm{mL}$ e avaliados quanto a: viabilidade por anexina $\mathrm{V}$ e Iodeto de propidio; polimerização de actina na presença de CXCL2; expressão de GRK2 por imunofluorescência e CXCR2 por citometria de fluxo. Também, neutrófilos isolados da medula óssea de camundongos selvagens foram incubados com ODN CpG durante duas horas, sendo após este período efetuados: ensaio de fagocitose com zimosan opsonizado; polimerização de actina na presença de zymosan opsonizado; teste de habilidade microbicida com bactérias obtidas do conteúdo cecal; produção de espécies reativas de oxigênio e óxido nítrico. 


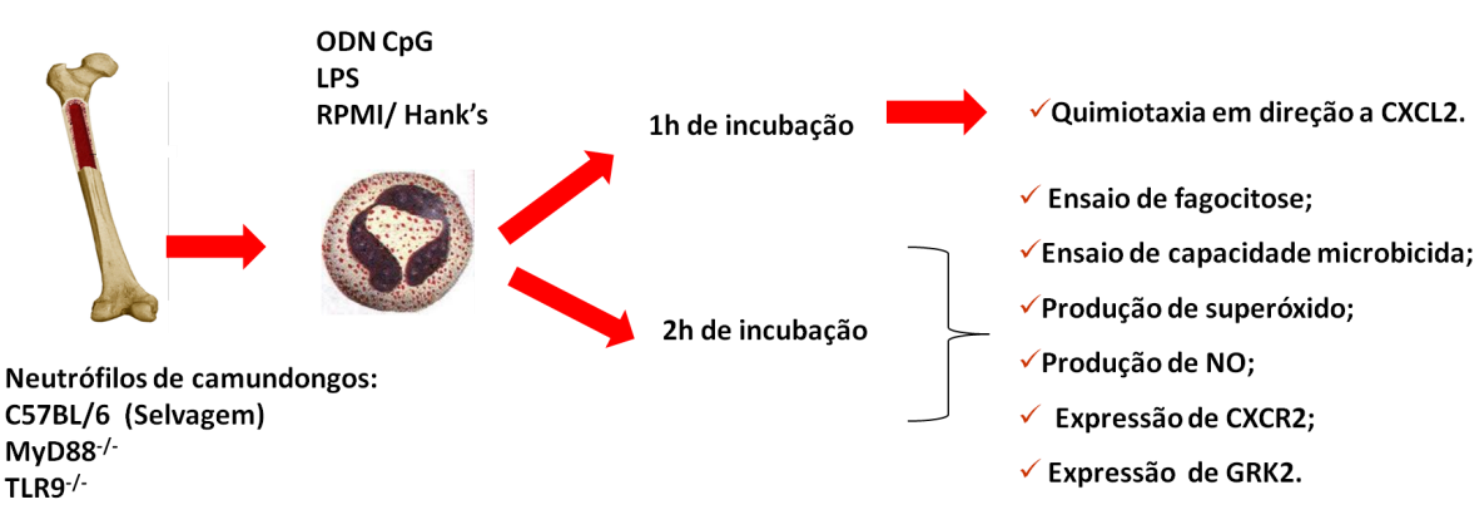

\subsection{Análises dos resultados}

Os dados (com exceção da curva de sobrevida e contagem bacteriana) foram expressos em gráficos de barras como média \pm erro padrão da média (EPM). O número amostral foi representado na legenda de cada figura. Antes das análises, foram realizados os estudos das distribuições das variáveis quanto à normalidade, homocedasticidade e esfericidade. Para as comparações entre as médias de ensaios com dois grupos experimentais utilizou-se teste $\mathrm{t}$, naqueles com mais de dois grupos experimentais foram utilizadas as provas de ANOVA one way seguida do pós-teste Tukey ou ANOVA two way seguida do pós-teste Bonferroni. Para comparação das médias obtidas na contagem bacteriana utilizou-se Mann-Whitney e os dados foram representados em gráficos de pontos ao redor da média. As razões de sobrevida foram expressas como porcentagem de animais vivos e a diferença entre elas obtida pelo teste Chi-Quadrado. Para a realização das análises estatísticas supracitadas foi 
utilizado programa estatístico computadorizado (GraphPad Prism Software, GraphPad Prism 5 Demo, USA, 2007). 
4. Resultados 


\subsection{Camundongos deficientes de TLR9 foram mais resistentes a CLP}

Para avaliar o papel do receptor toll-like 9 na sepse, animais selvagens (C57BL/6) e deficientes para o mesmo $\left(\mathrm{TLR}^{-/}\right)$foram submetidos ao modelo de ligadura e perfuração do ceco (CLP) em dois graus de severidade: sepse severa (SCLP) que resultou em $100 \%$ de mortalidade dos camundongos selvagens em 72 horas; e uma forma mais branda, sepse não-severa (NS-CLP), na qual a sobrevivência foi $100 \%$ durante os sete dias de observação. Os camundongos TLR9/- submetidos a S-CLP apresentaram aproximadamente $40 \%$ de sobrevivência ao longo dos sete dias avaliados (Figura 1), enquanto não diferiram dos selvagens em relação a NS-CLP.

Seis horas após a S-CLP, a deficiência de TLR9 favoreceu a migração de neutrófilos para o foco da infecção (Figura 2a e b), além de aumentar o recrutamento de outros tipos celulares (Figura $2 \mathrm{c}$ e d), como macrófagos $\left(\mathrm{F} 4 / 80^{+}\right)$e células dendríticas $\left(\mathrm{Cd} 11 \mathrm{c}^{+}\right)$. Camundongos TLR9 ${ }^{-/-}$também apresentaram menor seqüestro de neutrófilos no pulmão (Figura 3a e b) e menos bactérias no sangue e lavado peritoneal (Figuras 4a e b, respectivamente).

Os animais deficientes de TLR9 submetidos a S-CLP apresentaram menores níveis de TNF-alfa no soro (Figura 5a) seis horas após a CLP, o que implica em menor proporção da resposta inflamatória sistêmica relacionada ao maior controle da infecção.

Entre os camundongos selvagens e deficientes de TLR9 não foi observada diferença significativa nas quantidades de CXCL1 e CXCL2 no lavado peritoneal 
(Figura 5c-b) seis horas após a CLP. Portanto, o maior recrutamento de neutrófilos para o foco da infecção não se deveu a maior produção local de quimiocinas.

Dessa forma, na sepse severa (S-CLP), a ausência da ativação de TLR9 resultou em maior sobrevivência por prevenir a falência na migração dos neutrófilos para a cavidade peritoneal, o que permitiu maior controle da infecção localmente, havendo menor bacteremia e inflamação sistêmica. 


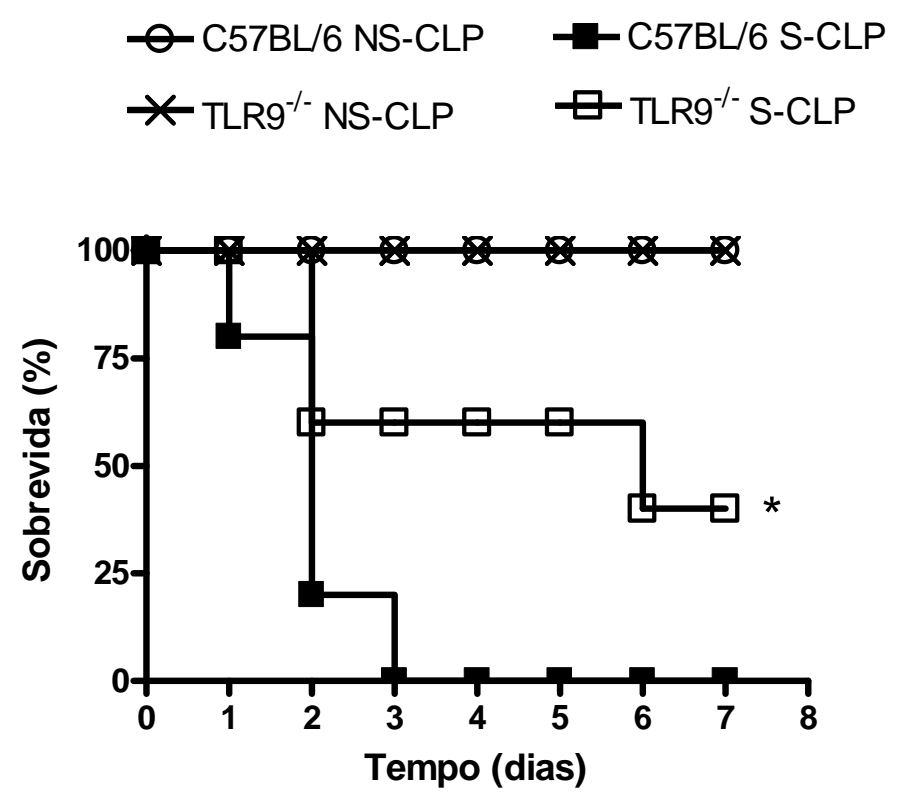

Figura 1. A deficiência de TLR9 confere maior sobrevivência a sepse polimicrobiana. Camundongos selvagens (C57BL/6) e deficientes de TLR9 $\left(\right.$ TLR9 $^{-/-}$) foram submetidos ao modelo de ligadura e perfuração do ceco (CLP) em dois diferentes graus de severidade: sepse severa (S-CLP) e sepse não severa (NSCLP). A sobrevida foi avaliada durante sete dias consecutivos e analisada pelo teste Chi-Quadrado $(n=15)$. ${ }^{*} \mathrm{p}<0,05$ em relação aos animais selvagens. 

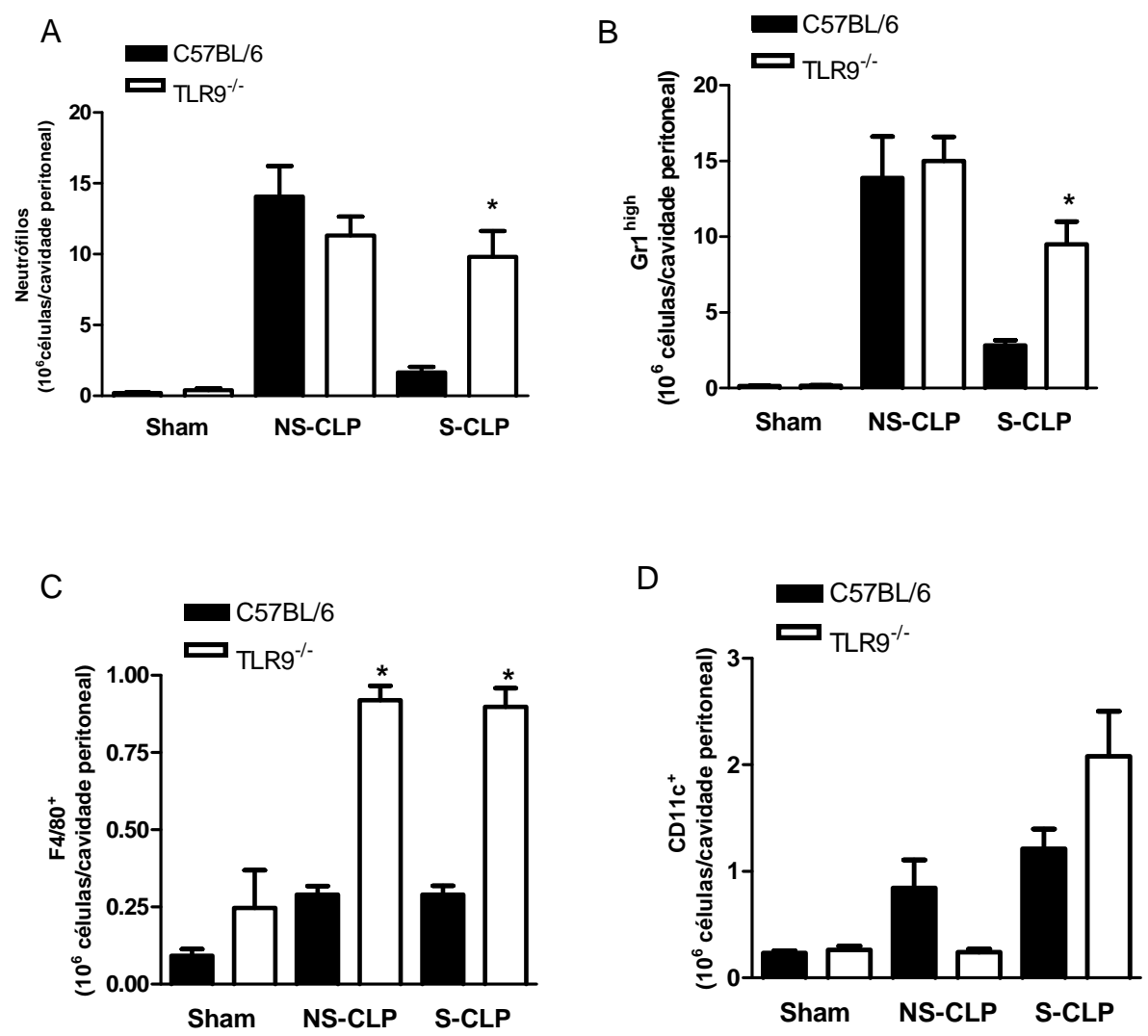

Figura 2. A deficiência de TLR9 aumenta o recrutamento de leucócitos para o foco da infecção após sepse severa (S-CLP). Camundongos selvagens (C57BL/6) e deficientes de TLR9 $\left(\right.$ TLR9 $^{-/}$) foram submetidos ao modelo de ligadura e perfuração do ceco (CLP) em dois diferentes graus de severidade: sepse severa (S-CLP) e sepse não severa (NS- CLP). Os animais sham são controles falso-operados. Após seis horas da CLP foi realizado o lavado peritoneal e este analisado por ensaio de citometria de fluxo quanto às populações: neutrófilos- $\mathrm{Gr} 1^{\text {high }}(\mathrm{b})$, macrófagos- F4/80 (c) e células dendríticas- $\mathrm{CD}_{11 \mathrm{c}^{+}}$(d). O número de neutrófilos também foi estabelecido a partir da contagem diferencial de leucócitos em lâmina (a). Para as comparações entre os grupos de animais utilizou-se ANOVA two way seguida pelo post-test de Bonferroni $(n=5)$. ${ }^{*} \mathrm{p}<0,05$ em relação aos animais selvagens. 
A

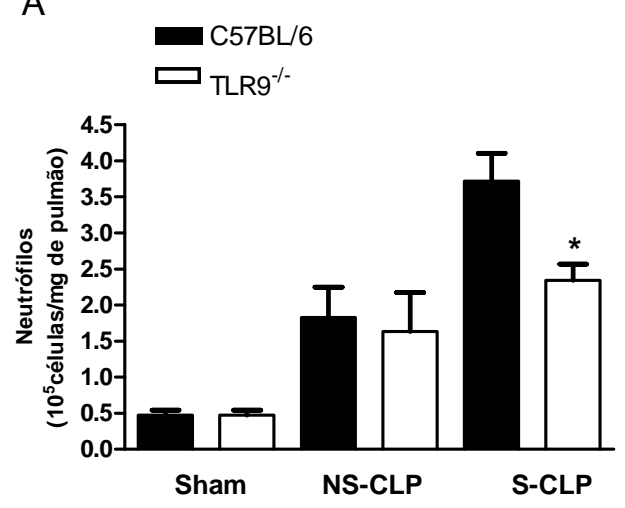

C

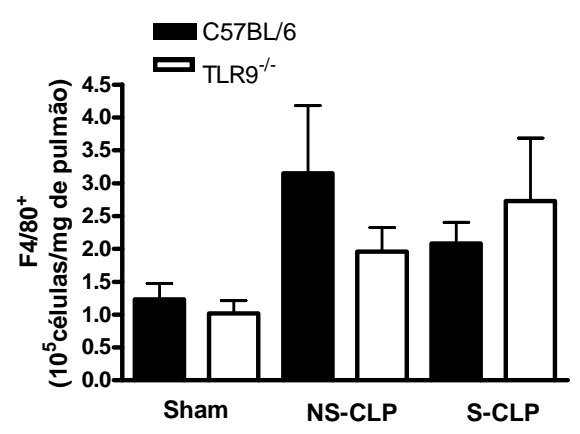

B

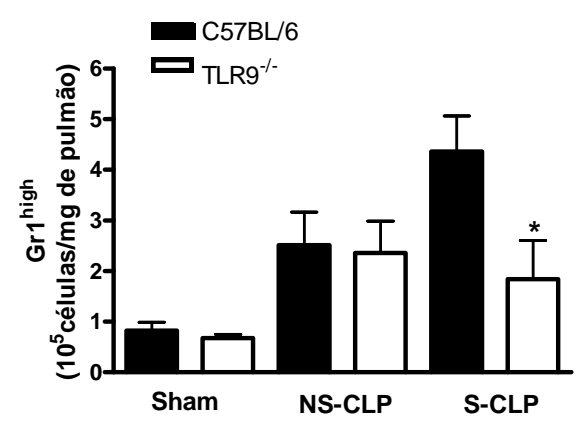

D

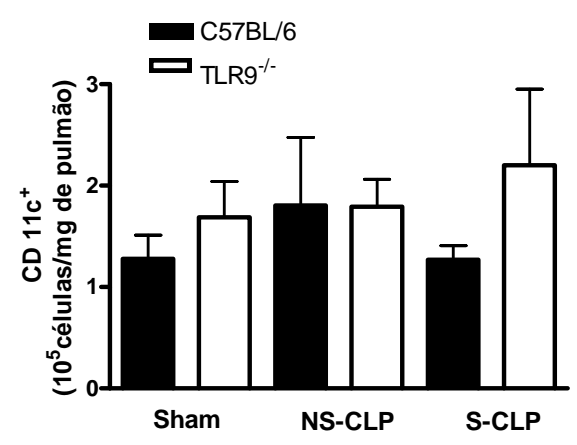

Figura 3. A deficiência de TLR9 reduz o seqüestro de neutrófilos no pulmão após sepse severa (S-CLP). Camundongos selvagens (C57BL/6) e deficientes de TLR9 $\left(\right.$ TLR9 $^{--}$) foram submetidos ao modelo de ligadura e perfuração do ceco (CLP) em dois diferentes graus de severidade: sepse severa (S-CLP) e sepse não severa (NS- CLP). Os animais sham são controles falso-operados. Após seis horas da CLP o pulmão foi retirado, processado e analisado por ensaio de citometria de fluxo quanto às populações: neutrófilos- $\mathrm{Gr} 1^{\text {high }}(\mathrm{b})$, macrófagos- $\mathrm{F} 4 / 80^{+}$(c) e células dendríticas- $\mathrm{CD}_{11 \mathrm{c}^{+}}$(d). O número de neutrófilos também foi estabelecido a partir do ensaio de mieloperoxidase a partir de curva preestabelecida (a). Para as comparações entre os grupos de animais utilizou-se ANOVA two way seguida pelo post-test de Bonferroni $(n=5)$. ${ }^{*} p<0,05$ em relação aos animais selvagens. 

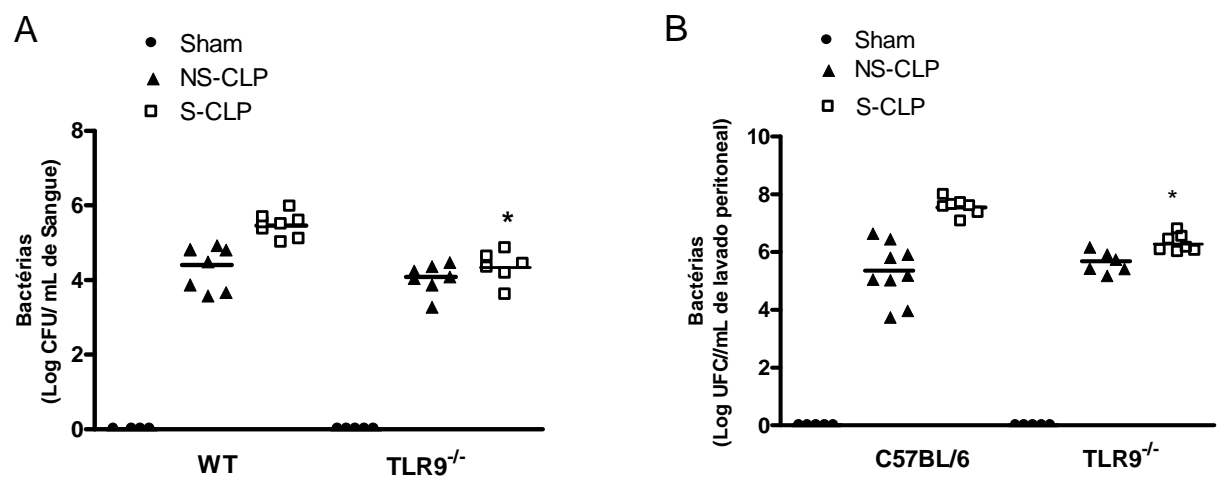

Figura 4. A deficiência de TLR9 reduz a contagem de bactérias no sangue e no lavado peritoneal após sepse severa (S-CLP). Camundongos selvagens (C57BL/6) e deficientes de TLR9 $\left(\right.$ TLR $^{-1-}$ ) foram submetidos ao modelo de ligadura e perfuração do ceco (CLP) em dois diferentes graus de severidade: sepse severa (S-CLP) e sepse não severa (NS- CLP). Os animais sham são controles falso-operados. Após seis horas foram realizados: lavado peritoneal e coleta do sangue. O cultivo foi realizado em placas estéreis contendo Agar Muller Hilton e após 18 horas contado o número de Unidades Formadoras de Colônia (UFC). As comparações entre os grupos de animais foram feitas por meio do teste de Mann-Whitney ( $n=5$ a 8). ${ }^{*} p<0,05$ em relação aos animais selvagens. 

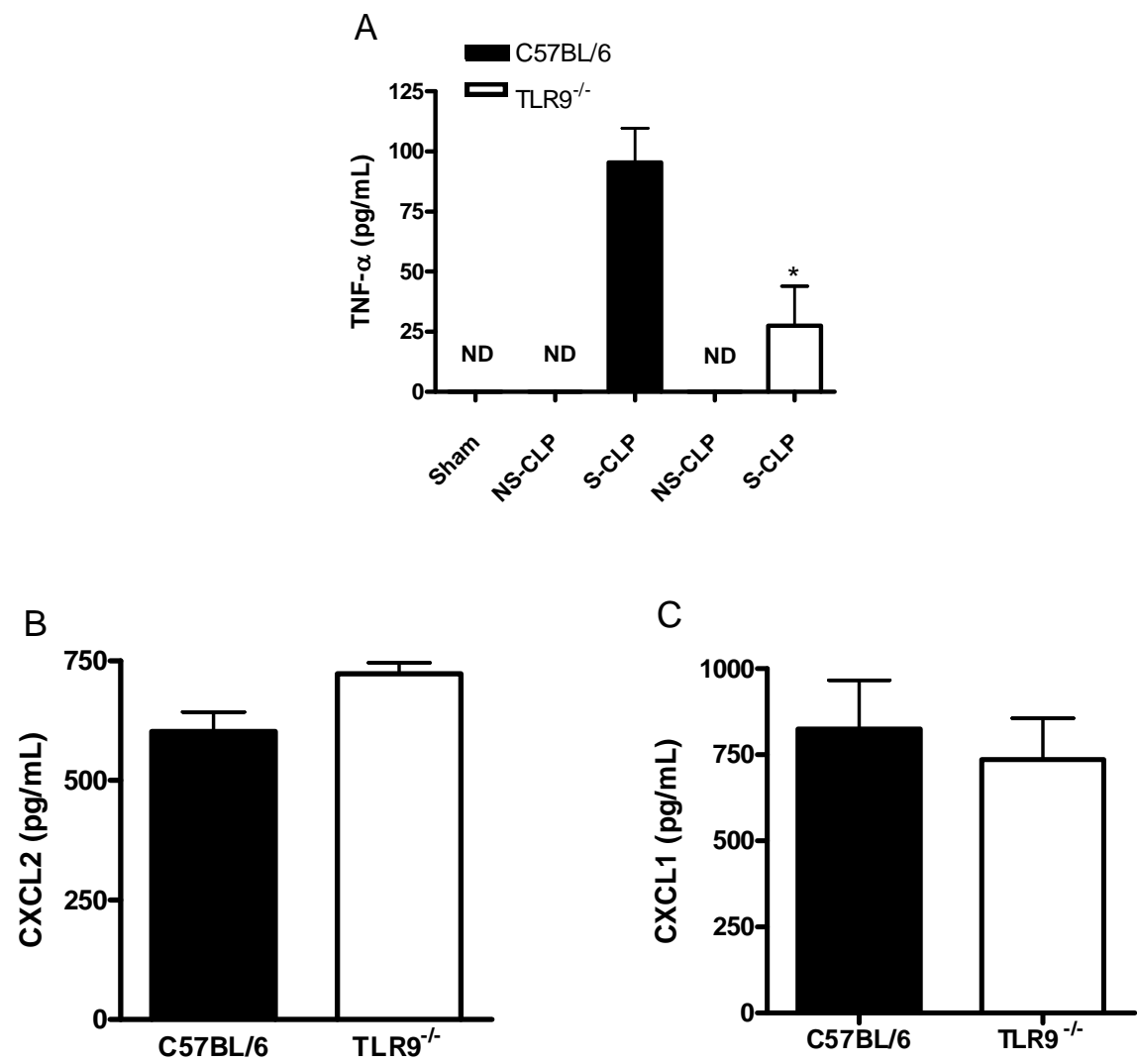

Figura 5. A deficiência de TLR9 reduz a inflamação sistêmica, mas não a resposta inflamatória local após sepse severa (S-CLP). Camundongos selvagens (C57BL/6) e deficientes de TLR9 $\left(\mathrm{TLR}^{-/}\right)$foram submetidos ao modelo de ligadura e perfuração do ceco (CLP) em dois diferentes graus de severidade: sepse severa (S-CLP) e sepse não severa (NS- CLP). Os animais sham são controles falso-operados. Após seis horas da cirurgia, realizou-se a coleta do sangue para obtenção do soro para dosagem de TNF- $\alpha$ (a), bem como lavado peritoneal para as dosagens de CXCL2 (b) e CXCL1 (c). Utilizou-se ELISA para quantificar as citocinas referidas. ${ }^{*} \mathrm{p}<0,05$ em relação aos animais selvagens. As comparações entre os grupos de animais foram feitas por meio de teste $\mathrm{t}$ para amostras independentes $(n=5)$. $* \mathrm{p}<0,05$ em relação aos animais selvagens. 


\subsection{Neutrófilos de camundongo expressam TLR9}

A expressão de TLR9 foi observada por meio do ensaio de citometria de fluxo em população $\mathrm{Gr} 1^{\text {high }}$ em sangue total obtido de camundongos naive, sham operados, bem como naqueles submetidos a CLP (Figura 6a -c). Quando a população Gr1 $1^{\text {high }}$ foi cruzada com a população de células marcadas com o anticorpo antiCD45r (B220), foram distinguidas duas populações isoladas (Figura 6b), o que exclui das análises a expressão de TLR9 por células dendríticas plasmocitóides (pDCs).

Após duas horas da cirurgia, a expressão de TLR9 em população Gr1 $1^{\text {high }}$ /F4/80- não diferiu entre os animais sham operados e os animais submetidos aos distintos graus de severidade da CLP (Figura 6c). 

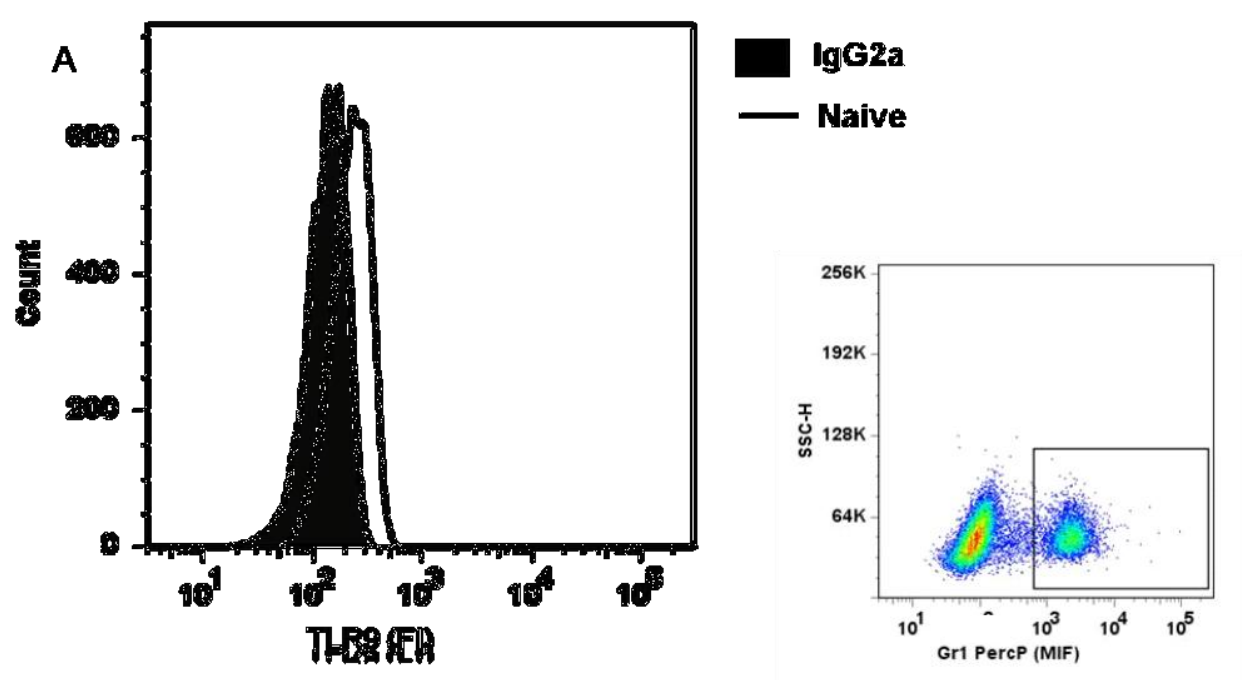

B

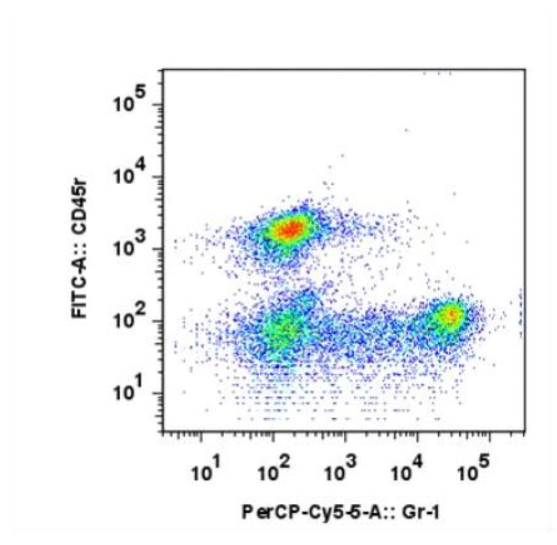

C

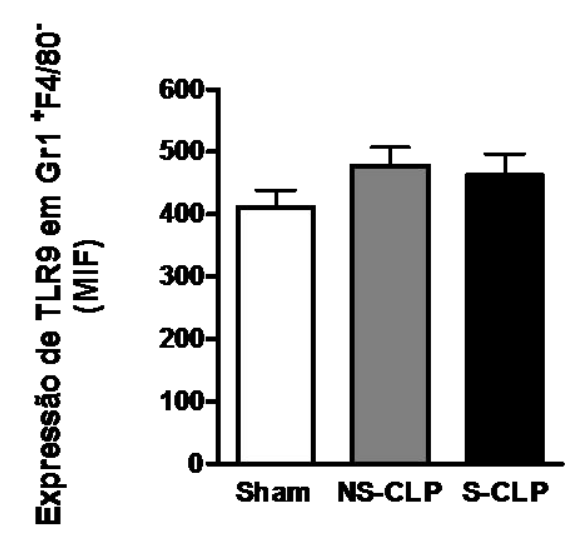

Figura 6. Neutrófilos de camundongo expressam TLR9. A expressão de TLR9 foi verificada em neutrófilos $\left(\mathrm{Gr} 1^{\text {high }}\right.$ ou $\left.\mathrm{Gr}^{+}{ }^{+} \mathrm{F} 4 / 80^{-}\right)$do sangue total. Expressão de TLR9 foi verificada em camundongos selvagens (C57BL/6) naive (a) e camundongos submetidos ao modelo de ligadura e perfuração do ceco (CLP) em dois diferentes graus de severidade: sepse severa (S-CLP) e sepse não severa (NS- CLP). Os animais sham são controles falso-operados (c). O sangue foi colhido duas horas após CLP. Em tubo separado, a população $\mathrm{Gr}^{+}$foi cruzada a marcada com anti-CD45R (b). O gráfico de pontos (b) representa o número de eventos adquiridos e o histograma (a) exprime a intensidade de fluorescência (FI). O gráfico de barras (c) expressa a mediana da intensidade de fluorescência (MIF). $(n=4)$ 


\subsection{A ativação de TLR9 inibiu a migração de neutrófilos para o foco da inflamação}

Para verificar o papel de TLR9 no recrutamento de neutrófilos para o foco da inflamação, camundongos selvagens, deficientes da proteína adaptadora MyD88 ou de TLR9 foram tratados i.v. com o agonista deste receptor (ODN CpG) ou PBS. Depois de 30 minutos, foi induzida peritonite estéril com tioglicolato injetado i.p., e, após quatro horas, quantificado o número de neutrófilos que migraram para a cavidade peritoneal e a infiltração destes polimorfonucleares no pulmão. Os animais selvagens tratados com ODN CpG apresentaram menor migração de neutrófilos para a cavidade peritoneal (Figura 7a) e maior seqüestro de neutrófilos no pulmão (Figura 7b) quando comparados aos controles que receberam PBS. Os camundongos MyD88/- e TLR9 ${ }^{-/-}$(Figura 7a e 7b) tratados com ODN CpG responderam ao estímulo com tiogliolato de forma semelhante aos controles injetados com PBS. Dessa forma, a ativação sistêmica de TLR9 via proteína adaptadora MyD88 promoveu inibição da migração de neutrófilos para o foco da inflamação e aumento da infiltração destes no pulmão.

Corroborando o menor número de neutrófilos observado na cavidade peritoneal, o tratamento com ODN CpG também reduziu o rolamento e a adesão dos leucócitos nas vênulas mesentéricas (Figuras 8a e b). Para excluir a possibilidade de o ODN CpG reduzir o rolamento e a adesão por atuar na superfície dos leucócitos ou demais receptores de DNA intracelulares e não via TLR9, como controle utilizou-se um ODN com seqüência que não possui o dinucleotídeo CpG não metilado. 
Para verificar se a ativação de TLR9 diretamente em neutrófilos foi responsável por reduzir a migração destes para o foco da inflamação realizou-se ensaio de transferência adotiva. Com esta finalidade, neutrófilos isolados da medula óssea de camundongos selvagens (C57BL/6) foram marcados com CFSE e injetados em animais selvagens e deficientes da proteína adaptadora MyD88. Após 30 minutos, os animais foram tratados com ODN CpG ou PBS i.v. e induzida peritonite estéril com tioglicolato i.p. Depois de quatro horas, realizou-se o lavado peritoneal e o número de neutrófilos marcados foi estabelecido em citômetro de fluxo a partir da avaliação de um milhão de eventos. Neutrófilos isolados da medula óssea provindos de camundongos selvagens marcados com CFSE e transferidos para MyD88 ${ }^{-/-}$ migraram menos para a cavidade peritoneal sob estímulo de tioglicolato (Figura 9). Tal evento demonstra uma atuação direta do ODN CpG em neutrófilos, tendo em vista que somente os neutrófilos provindos de camundongos selvagens sofreram inibição da migração por ODN CpG (Figura 7a e 9), o que não foi observado em neutrófilos provindos de camundongos MyD88 ${ }^{-/-}$(Figura 7a). A inibição da migração de neutrófilos selvagens nos animais deficientes de MyD88 tratados com ODN CpG elimina a possibilidade de outras células que também expressam o receptor, tais como células dendríticas, macrófagos e linfócitos T, produzirem fatores inibitórios sobre a migração dos neutrófilos.

Assim, a ativação de TLR9 em neutrófilos promove per se a inibição da migração destes para o sítio da inflamação. 
A

口PBS

ODN CpG $(0,9 \mathrm{mg} / \mathrm{kg})$

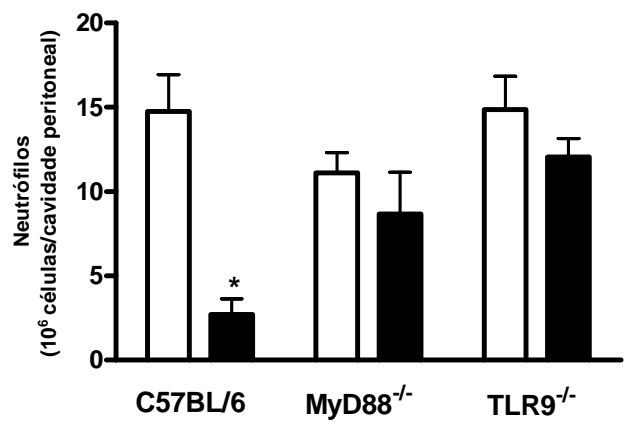

B $2 \mathrm{PBS}$

ODN CpG $(0,9 \mathrm{mg} / \mathrm{kg})$

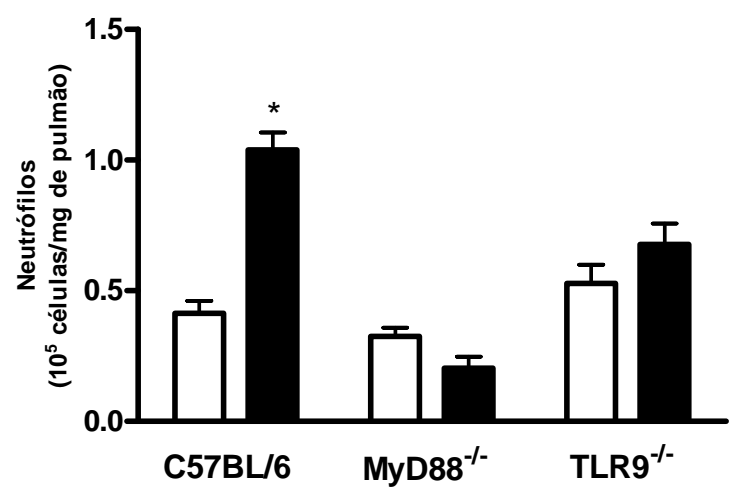

Figura 7. A ativação sistêmica de TLR9 reduz a migração de neutrófilos para o foco da inflamação e aumenta o seqüestro de neutrófilos no pulmão. Camundongos selvagens (C57BL/6), deficientes para a proteína adaptadora

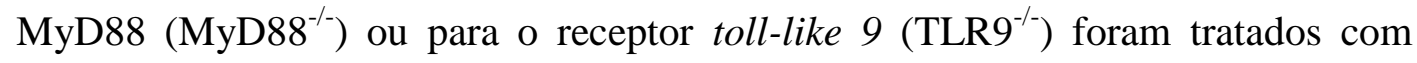
ODN CpG $(0,9 \mathrm{mg} / \mathrm{kg})$ ou solução salina tamponada/fosfatada (PBS) i.v. e, após 30 minutos, se administrou tioglicolato 3\% i.p. Efetuou-se o lavado peritoneal após quatro horas da injeção do tioglicolato e foram avaliados: (a) contagem de neutrófilos que migraram para o foco da inflamação $(n=5)$ e ensaio de mieloperoxidase (b) para quantificar o infiltrado de neutrófilos no pulmão $(n=5)$. Para comparações entre os grupos utilizou-se ANOVA two way seguida do pósteste de Bonferroni. * $\mathrm{p}<0,05$. 
A

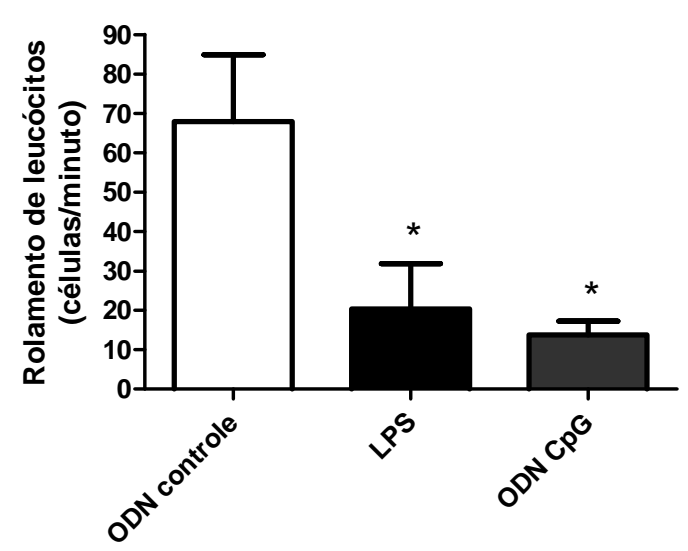

B

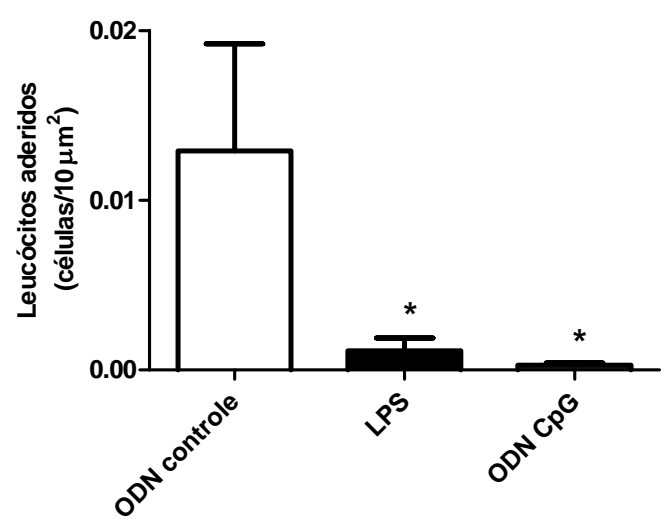

Figura 8. A ativação sistêmica de TLR9 reduz o rolamento e adesão dos leucócitos. Camundongos selvagens (C57BL/6) foram tratados com ODN CpG $(0,9 \mathrm{mg} / \mathrm{kg})$, ou LPS $(15 \mathrm{mg} / \mathrm{kg})$, ou solução salina tamponada/fosfatada (PBS) i.v. e após 30 minutos injetados com tioglicolato $3 \%$ i.p. Após três horas da injeção de tioglicolato, os animais foram anestesiados com quetamina $(100 \mathrm{mg} / \mathrm{kg}) /$ xilazina $(15 \mathrm{mg} / \mathrm{kg})$ e submetidos ao ensaio de microscopia intravital. Depois de identificada uma vênula do mesentério, foram quantificados: o número de leucócitos que rolaram sobre o vaso e o número de leucócitos aderidos no endotélio, durante cinco minutos $(n=5)$. Para comparações entre os grupos utilizou-se teste de Kruskal-Wallis. ${ }^{*} \mathrm{p}<0,05$ em relação ao grupo tratado com ODN controle. 


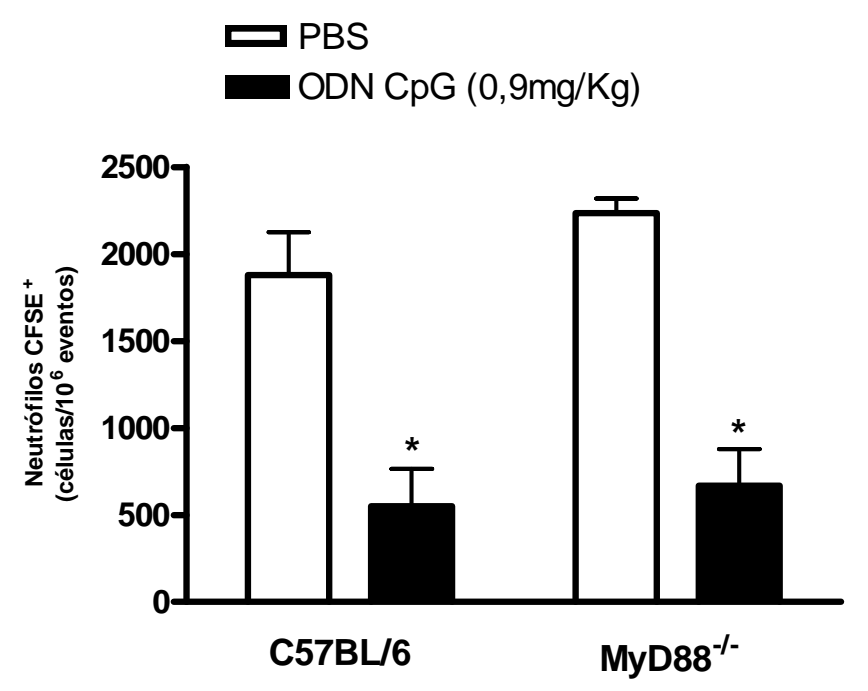

Figura 9. A ativação de TLR9 diretamente em neutrófilos reduz a migração destes para o foco da inflamação- ensaio de transferência adotiva. Neutrófilos foram isolados da medula óssea de camundongos selvagens (C57BL/6) e marcados com CFSE. As células marcadas $\left(3 \times 10^{6}\right)$ foram injetadas i.v. em camundongos selvagens (C57BL/6) e deficientes para a proteína adaptadora MyD88 (MyD88 ${ }^{-/-}$). Os animais foram tratados com ODN CpG $(0,9 \mathrm{mg} / \mathrm{kg})$ ou solução salina tamponada/fosfatada (PBS) i.v. e após 30 minutos injetados com tioglicolato 3\% i.p. Quatro horas após foi realizado lavado peritoneal e as células adquiridas em citômetro de fluxo. Os dados representam o número de neutrófilos provindos de camundongos selvagens marcados com CFSE que migraram para cavidade peritoneal em $10^{6}$ eventos adquiridos pelo citômetro de fluxo. Para comparação entre os grupos utilizou-se ANOVA two way. ${ }^{*} \mathrm{p}<0,05$ em relação ao controle tratado com PBS. 


\subsection{A ativação de TLR9 em neutrófilos prejudica a quimiotaxia para CXCL2}

Alves-Filho et al (2008 e 2010) observaram que a ativação de TLR2 e TLR4 inibem a migração de neutrófilos para o foco inflamatório/infeccioso na sepse por inibirem a resposta quimiotáxica em direção a CXCL2. Para investigar se TLR9 atua sobre a quimiotaxia, neutrófilos de camundongos selvagens, deficientes de MyD88

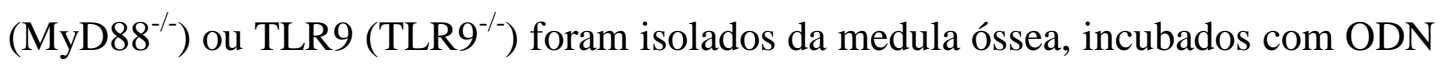
CpG e colocados em câmara de Boyden modificada para migrarem em direção a CXCL2. Os neutrófilos provindos de camundongos selvagens incubados com ODN CpG apresentaram menor resposta quimiotáxica quando comparados aos controles que permaneceram somente em meio de cultura RPMI (Figura10a). Tal inibição da resposta quimiotáxica a CXCL2 não foi observada nos neutrófilos deficientes de TLR9 e MyD88 (Figura 10b). Neutrófilos provindos de camundongos selvagens incubados com ODN CpG também apresentaram menor polimerização de actina quando colocados na presença de CXCL2 (Figura 11).

Corroborando a menor resposta quimiotáxica em direção a CXCL2 observada pela exposição in vitro ao ODN CpG também foi verificada menor quimiotaxia em direção a CXCL1 e CXCL2 (Figura 12) de neutrófilos isolados do sangue de camundongos selvagens após duas horas do tratamento com ODN CpG em relação aos tratados com solução salina tamponada fosfatada (PBS).

Além disso, neutrófilos isolados do sangue de camundongos submetidos a SCLP apresentaram inibição da quimiotaxia em direção a CXCL2, o que foi não observado em animais deficientes de TLR9 (Figura 13). 
A viabilidade dos neutrófilos (Figura 14), aferida em citômetro de fluxo pelo ensaio de anexina V e PI (iodeto de propidio), não foi alterada pela incubação in vitro com ODN CpG nas concentrações utilizadas. A anexina é uma proteína que se liga á resíduos de fosfatidilserina expressos na superfície externa de células apoptóticas, enquanto o PI, impermeável a células íntegras, possui grande capacidade de se ligar ao DNA quando há ruptura da membrana plasmática (O’Brien e Bolton, 1995).

Dessa forma, os resultados observados pela exposição dos neutrófilos ao ODN CpG in vivo e in vitro corroboram a inibição da migração de neutrófilos em direção a quimiocina CXCL2 quando TLR9 é ativado. 

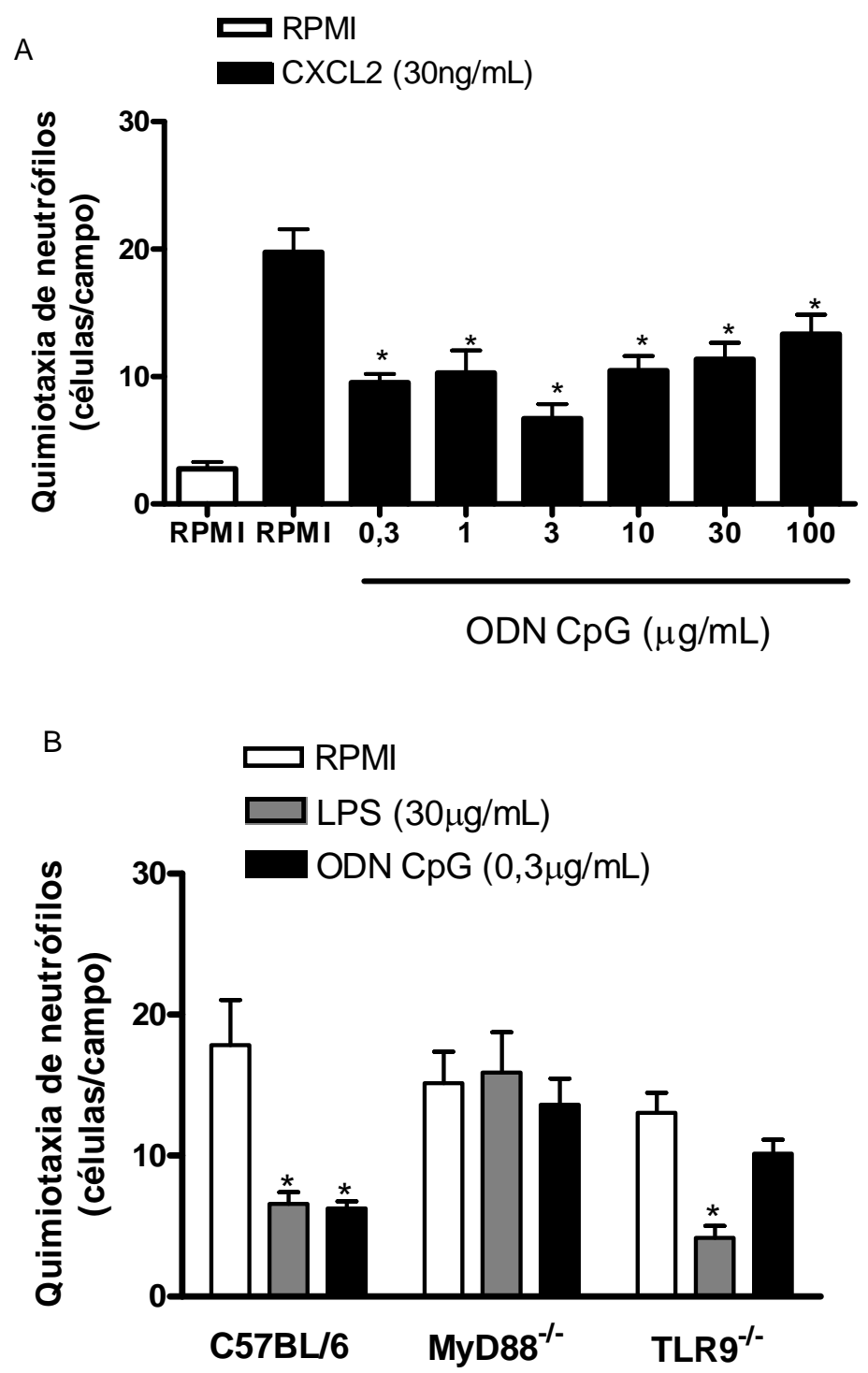

Figura 10. A ativação de TLR9 em neutrófilos reduz a quimiotaxia em direção a CXCL2. Neutrófilos isolados da medula óssea de camundongos selvagens (C57BL/6), deficientes de MyD88 $\left(\mathrm{MyD}^{-/-}\right)$ou deficientes do receptor toll-like 9 (TLR9 $\left.^{-/}\right)$foram incubados com ODN CpG $(0,3 \mu \mathrm{g} / \mathrm{mL})$, em meio RPMI, ou com lipopolossacarídeo-LPS $(30 \mu \mathrm{g} / \mathrm{mL})$ durante uma hora, e posteriormente colocados em câmara de Boyden modificada para migrarem em direção a CXCL2 (30ng/mL) durante uma hora. Para comparação entre os grupos utilizou-se ANOVA one (a) ou two way (b) seguida pelo pós-teste de Bonferroni. ${ }^{*} \mathrm{p}<0,05$. Os gráficos representam três experimentos em quadruplicata realizados isoladamente. 

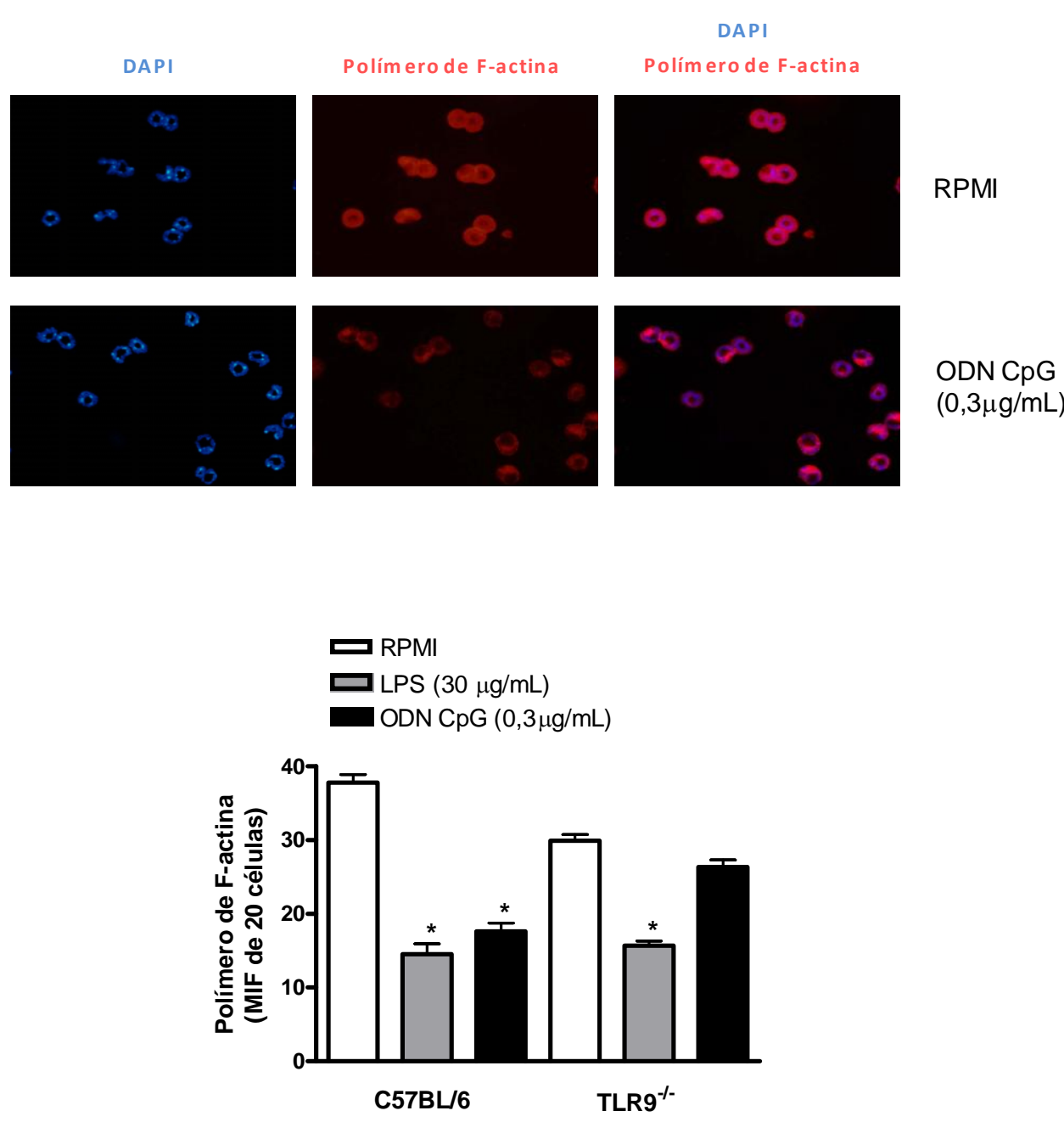

Figura 11. A ativação de TLR9 em neutrófilos reduz a polimerização de actina estimulada por CXCL2. Neutrófilos isolados da medula óssea de camundongos selvagens (C57BL/6) e deficientes do receptor toll-like 9 $\left(\mathrm{TLR}^{-/-}\right)$foram incubados com ODN CpG $(0,3 \mu \mathrm{g} / \mathrm{mL})$, em meio RPMI, ou com lipopolossacarídeo-LPS $(30 \mu \mathrm{g} / \mathrm{mL})$ durante duas horas, e posteriormente estimulados com CXCL2 $(30 \mathrm{ng} / \mathrm{mL})$ durante um minuto. Para verificar a formação do polímero de F-actina utilizou-se faloidina associada a rodamina. A média de intensidade de fluorescência (MIF) foi determinada com uso do software Image J. Para comparação entre os grupos utilizou-se ANOVA two way seguida pelo pós-teste de Bonferroni. * ${ }^{*}<0,05$. As figuras e gráfico representam três experimentos em triplicata realizados isoladamente. Para facilitar a leitura utilizou-se o 4, 6-diamidino-2fenilindol (DAPI) para marcação da cromatina. 


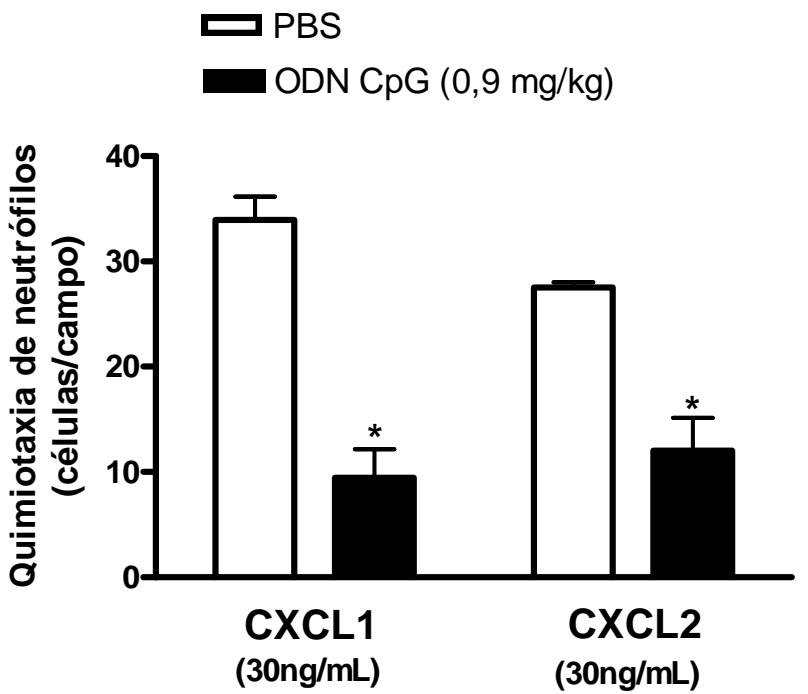

Figura 12. A ativação sistêmica de TLR9 reduz a quimiotaxia de neutrófilos em direção a quimiocinas CXCL1 e CXCL2. Camundongos selvagens (C57BL/6) foram tratados com ODN $\mathrm{CpG}(0,9 \mathrm{mg} / \mathrm{kg})$ ou solução salina tamponada/fosfatada (PBS) i.v. e após duas horas eutanasiados para obtenção do sangue. Os neutrófilos isolados do sangue foram colocados em câmara de Boyden modificada para migrarem em direção a CXCL1 (30ng/mL) ou CXCL2 (30ng/mL) durante uma hora. Para comparação entre os grupos utilizou-se teste t. ${ }^{*} p<0,05$. Os gráficos representam dois experimentos em quadruplicata realizados isoladamente. 


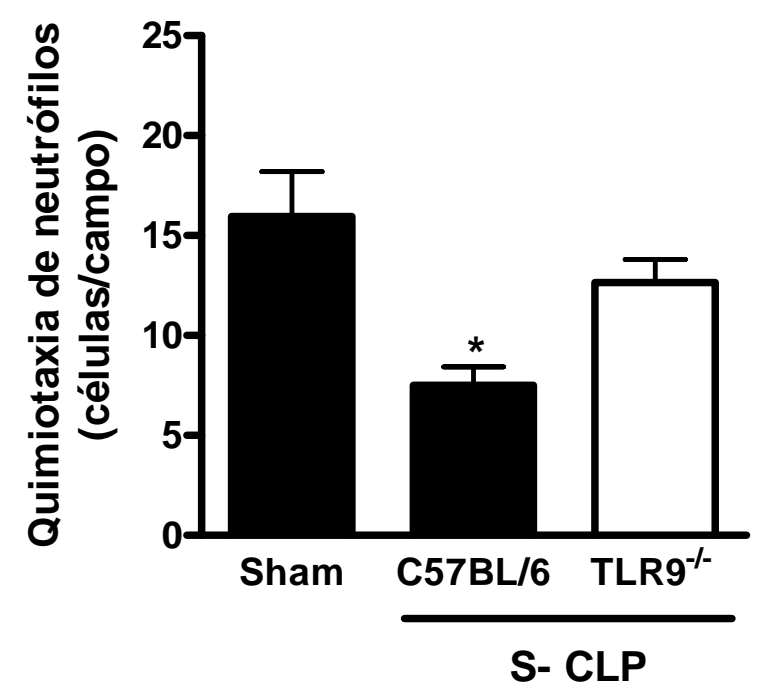

Figura 13. A ativação sistêmica de TLR9 durante a sepse severa (S-CLP) reduz a quimiotaxia de neutrófilos em direção a quimiocina CXCL2. Camundongos selvagens (C57BL/6) ou deficientes de toll-like receptor 9 (TLR9 ${ }^{-/}$) foram submetidos ao modelo de ligadura e perfuração do ceco (CLP) na forma de sepse severa (S-CLP). Os animais sham são controles selvagens falso-operados. Após duas horas da cirurgia os camundongos foram eutanasiados para obtenção do sangue. Os neutrófilos isolados do sangue foram colocados em câmara de Boyden modificada para migrarem em direção a CXCL2 $(30 \mathrm{ng} / \mathrm{mL})$ durante uma hora. Para comparação entre os grupos utilizou-se teste $\mathrm{t}$. ${ }^{*} \mathrm{p}<0,05$ em relação ao sham operado. O gráfico representa dois experimentos em quadruplicata realizados isoladamente. 


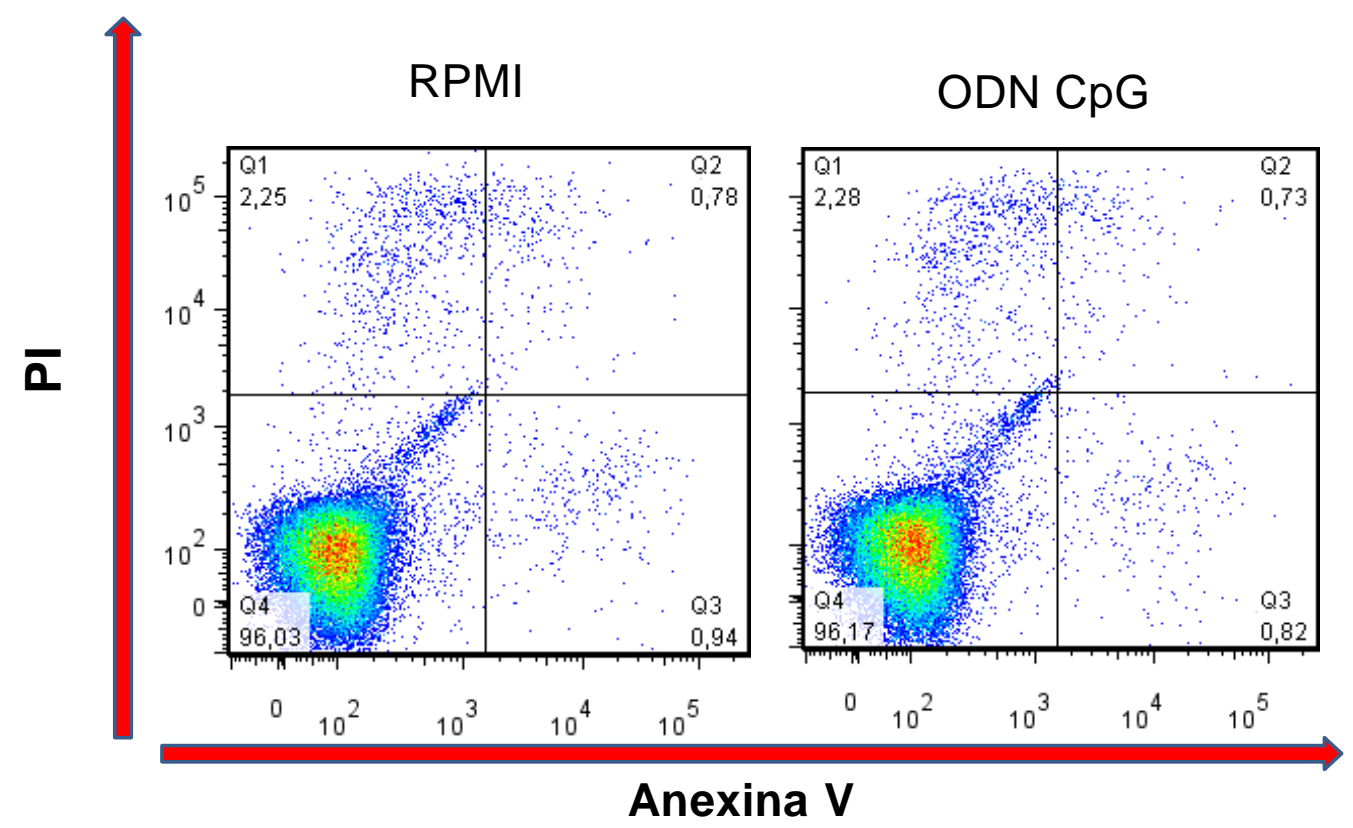

Figura 14. A incubação de neutrófilos com ODN CpG não altera a viabilidade dos mesmos. Neutrófilos isolados da medula óssea de camundongos selvagens (C57BL/6) foram incubados com ODN CpG $(10 \mu \mathrm{g} / \mathrm{mL})$, em meio RPMI, durante duas horas. Os neutrófilos foram incubados com anexina $\mathrm{V}$ durante quinze minutos e iodeto de propídeo (PI) por um minuto, sendo a marcação das células avaliada em citômetro de fluxo. Os gráficos de pontos representam o número de eventos, sendo cada evento uma célula, bem como a proporção de células marcadas por anexina V e PI. 


\subsection{A ativação de TLR9 induz a internalização de CXCR2 via GRK2 em neutrófilos}

Receptores acoplados a proteína G (GPCRs) têm sua ativação negativamente regulada por meio de proteínas kinases específicas (GrKs) as quais controlam a presença destes receptores na superfície das células. A fosforilação dos GPCRs por GRKs aumenta a afinidade destes receptores pela proteína adaptadora arrestina, o que permite a mobilização de clatrina e endocitose (Ferguson et al., 1996; Moore et al., 2007).

Em pacientes sépticos a maior expressão de GRK2 em neutrófilos foi relacionada ao prejuízo na quimiotaxia dos neutrófilos em direção a CXCL8 (Arraes et al., 2006). Além disso, a ativação de TLR2 e TLR4 foi associada a dessensibilização de CXCR2 via aumento da expressão de GRK2 em neutrófilos (Alves-Filho et al., 2008; Alves-Filho et al., 2010).

Para verificar se a ativação de TLR9 inibe a quimiotaxia em direção a CXCL2 por induzir a internalização do receptor quimiotáxico correspondente, camundongos selvagens foram tratados i.v. com ODN CpG $(0,9 \mathrm{mg} / \mathrm{kg})$ e após duas horas verificada a expressão de CXCR2 na superfície, assim como a indução de GRK2 no interior dos neutrófilos. O tratamento i.v. com ODN $\mathrm{CpG}$ reduziu a expressão de CXCR2 (Figura 15) e aumentou a expressão de GRK2 (Figura 16) nos neutrófilos do sangue, assim como o tratamento i.v. com LPS $(15 \mathrm{mg} / \mathrm{Kg})$. Além disso, a incubação de neutrófilos isolados da medula óssea com ODN CpG durante duas horas reduziu a expressão de CXCR2 (Figura 17a), enquanto aumentou a expressão de GRK2 (Figura 18). Corroborando a importância da GRK2 na dessensibilização de CXCR2, a inibição de GRK2 preveniu a redução da quimiotaxia 
induzida pela ativação de TLR9 (Figura 17b), bem como a dessensibilização de CXCR2 (Figura 17a).

A incubação de neutrófilos isolados da medula óssea durante uma hora com ODN CpG não foi capaz de alterar a expressão de CXCR2 (Figura 19a) ou induzir a expressão de GrK2 (Figura 19b), diferentemente do observado com a estimulação dos neutrófilos com LPS. O fato de TLR4 estar localizado na superfície da membrana plasmática pode ter favorecido o rápido reconhecimento e conseqüente efeito precoce do LPS sobre os neutrófilos quando comparado ao ODN CpG promovendo a ativação de TLR9. A ativação de TLR9 é um processo mais demorado que TLR4, pois necessita da fagocitose para o reconhecimento. $O$ ensaio de quimiotaxia obteve resposta de inibição da migração com uma hora de incubação das células com o ODN CpG, pois os neutrófilos permaneceram em contato com ODN CpG, na realidade, durante duas horas, uma hora na estufa para a incubação, e outra na própria câmara de Boyden.

Também foi verificado que a expressão de CXCR2 na superfície de neutrófilos do sangue reduziu nos camundongos selvagens após S-CLP, porém isto foi observado em menor intensidade nos animais deficientes de TLR9 (Figura 20). A expressão de GRK2 também foi menor nos camundongos TLR9 ${ }^{-/-}$submetidos a SCLP quando comparados aos selvagens (Figura 21).

Tendo-se em vista a menor expressão de CXCR2 e aumento de GRK2 nos neutrófilos quando TLR9 é ativado por ODN CpG, sugere-se que TLR9 leva a dessensibilização de CXCR2 via GRK2. 

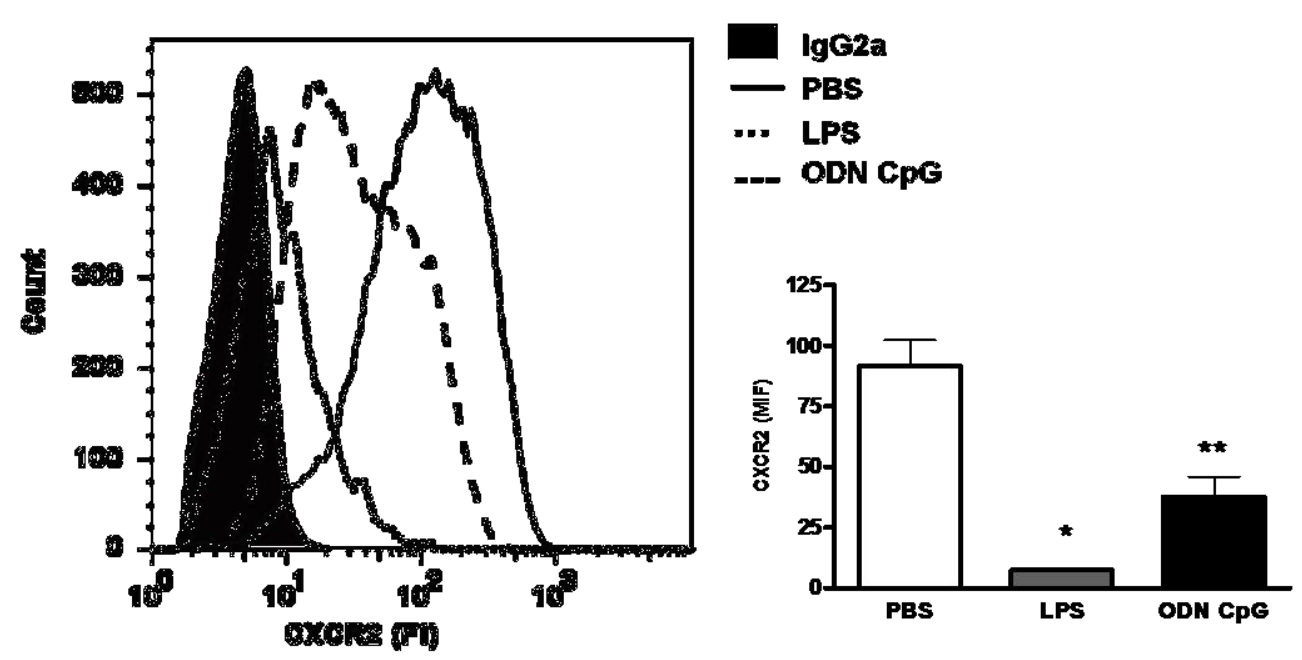

Figura 15. A ativação sistêmica de TLR9 induz a dessensibilização de CXCR2 em neutrófilos do sangue. Camundongos selvagens (C57BL/6) foram tratados com ODN CpG $(0,9 \mathrm{mg} / \mathrm{kg})$, ou lipopolissacarídeo-LPS $(15 \mathrm{mg} / \mathrm{kg})$, ou solução salina tamponada/fosfatada (PBS) i.v. e após duas horas eutanasiados para obtenção de sangue. A expressão de CXCR2 foi verificada em população Gr1 ${ }^{\text {high }}$ em citômetro de fluxo. O histograma e gráfico representam a intensidade de fluorescência e mediana de intensidade de fluorescência (MIF), respectivamente. Para comparações entre os grupos utilizou-se ANOVA one way seguida do pósteste de Bonferroni. **p<0,05 em relação ao controle PBS; ${ }^{*} \mathrm{p}<0,05$ em relação ao grupo tratado com ODN CpG. IgG2a: isotipo controle. 

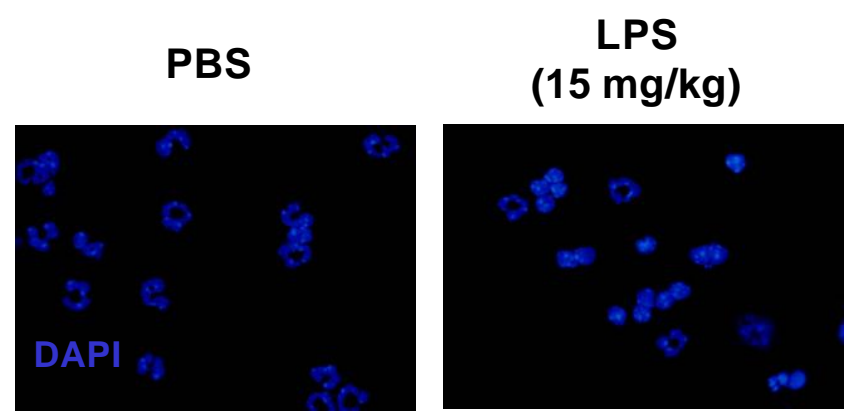

ODN CpG
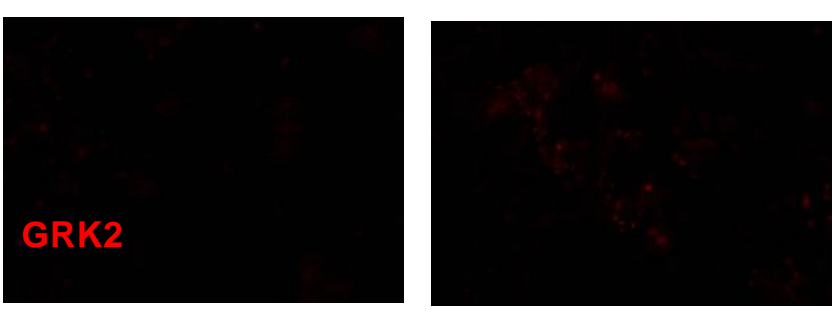

$(0,9 \mathrm{mg} / \mathrm{kg})$
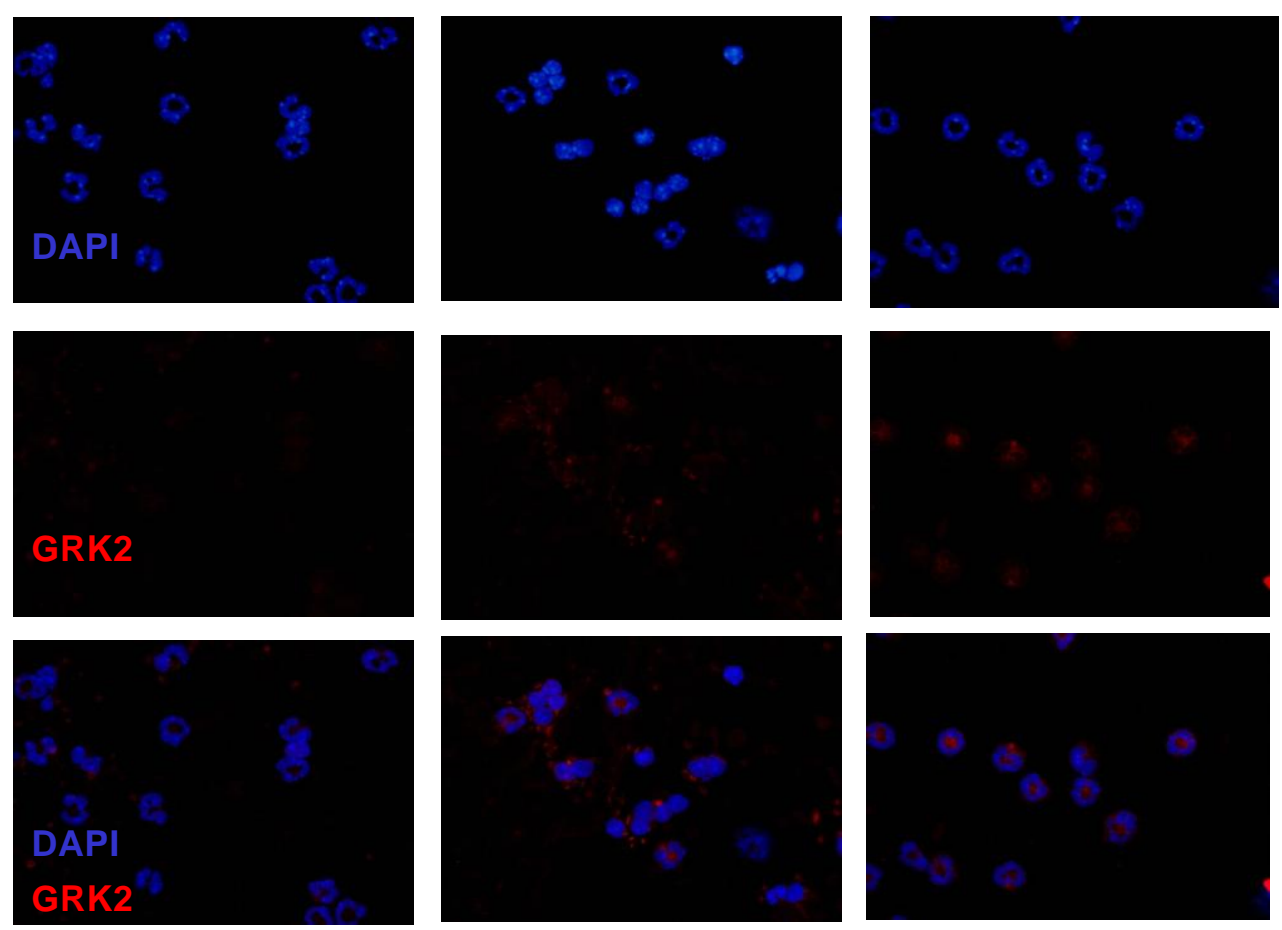

Figura 16. A ativação sistêmica de TLR9 aumenta a expressão de GRK2 em neutrófilos do sangue. Camundongos selvagens (C57BL/6) foram tratados com ODN CpG $(0,9 \mathrm{mg} / \mathrm{kg})$, ou lipopolissacarídeo-LPS $(15 \mathrm{mg} / \mathrm{kg})$, ou solução salina tamponada/fosfatada (PBS) i.v. e após duas horas eutanasiados para obtenção de sangue. A expressão de GRK2 foi verificada em neutrófilos isolados do sangue. As figuras são representativas de três experimentos realizados isoladamente. Para facilitar a leitura utilizou-se o 4, 6-diamidino-2-fenilindol (DAPI) para marcação da cromatina. 
A

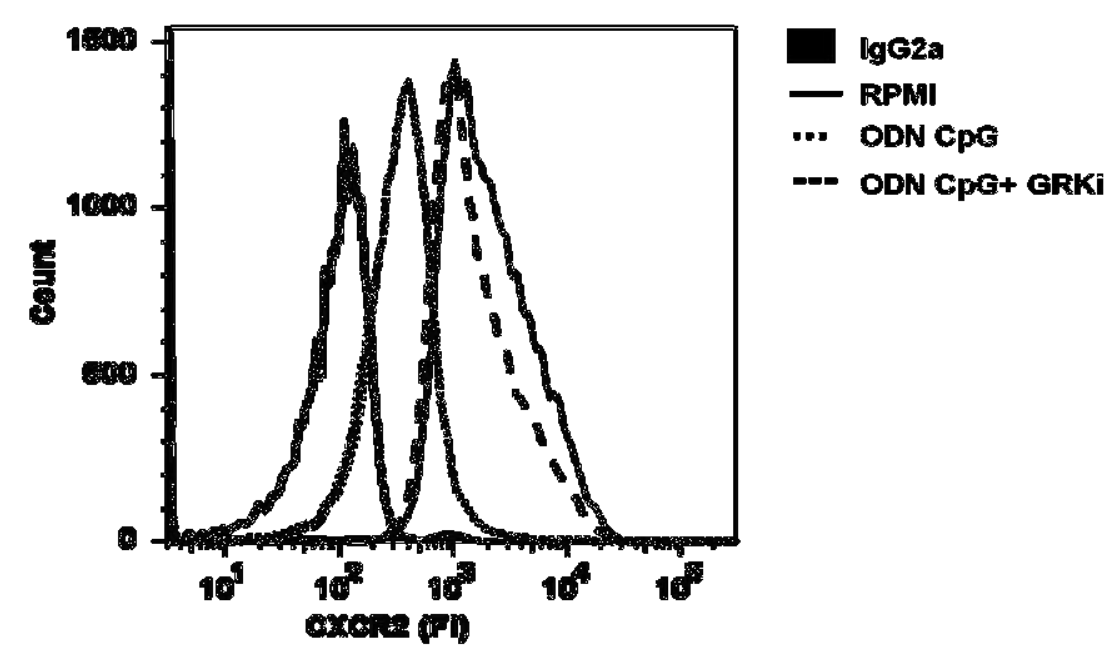

B

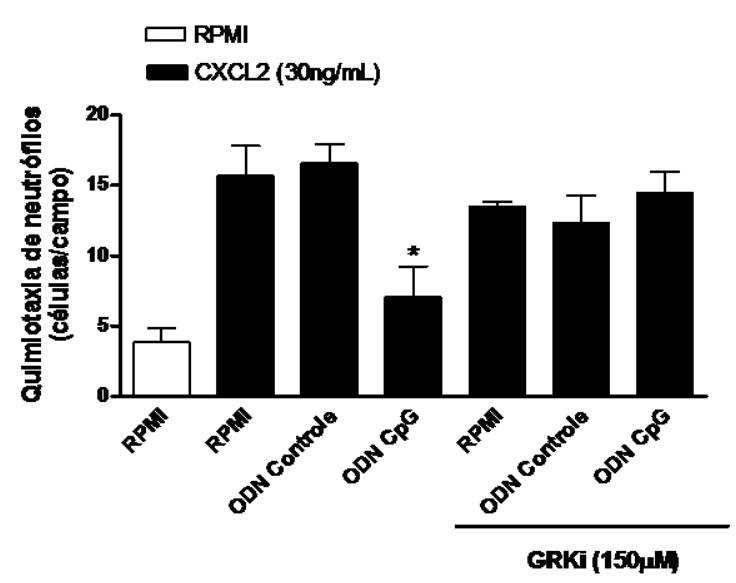

Figura 17. A ativação de TLR9 em neutrófilos induz a dessensibilização de CXCR2 via GRK2. Neutrófilos foram isolados da medula óssea de camundongos selvagens (C57BL/6), pré-incubados durante 30 minutos com inibidor de GRK $(\mathrm{GRKi}, 150 \mu \mathrm{M})$ e incubados com ODN CpG $(0,3 \mu \mathrm{g} / \mathrm{mL})$ ou ODN Controle $(0,3 \mu \mathrm{g} / \mathrm{mL})$ em meio RPMI. Após uma hora foi verificada a quimiotaxia (b) em direção a CXCL2 (30ng/mL) e depois de duas horas a expressão de CXCR2 em população Gr $1^{\text {high }}$ em citômetro de fluxo (a). O histograma representa a intensidade de fluorescência (FI). Para comparações entre os grupos utilizou-se ANOVA two way seguida do pós-teste de Bonferroni. *p<0,05 em relação ao controle RPMI. 

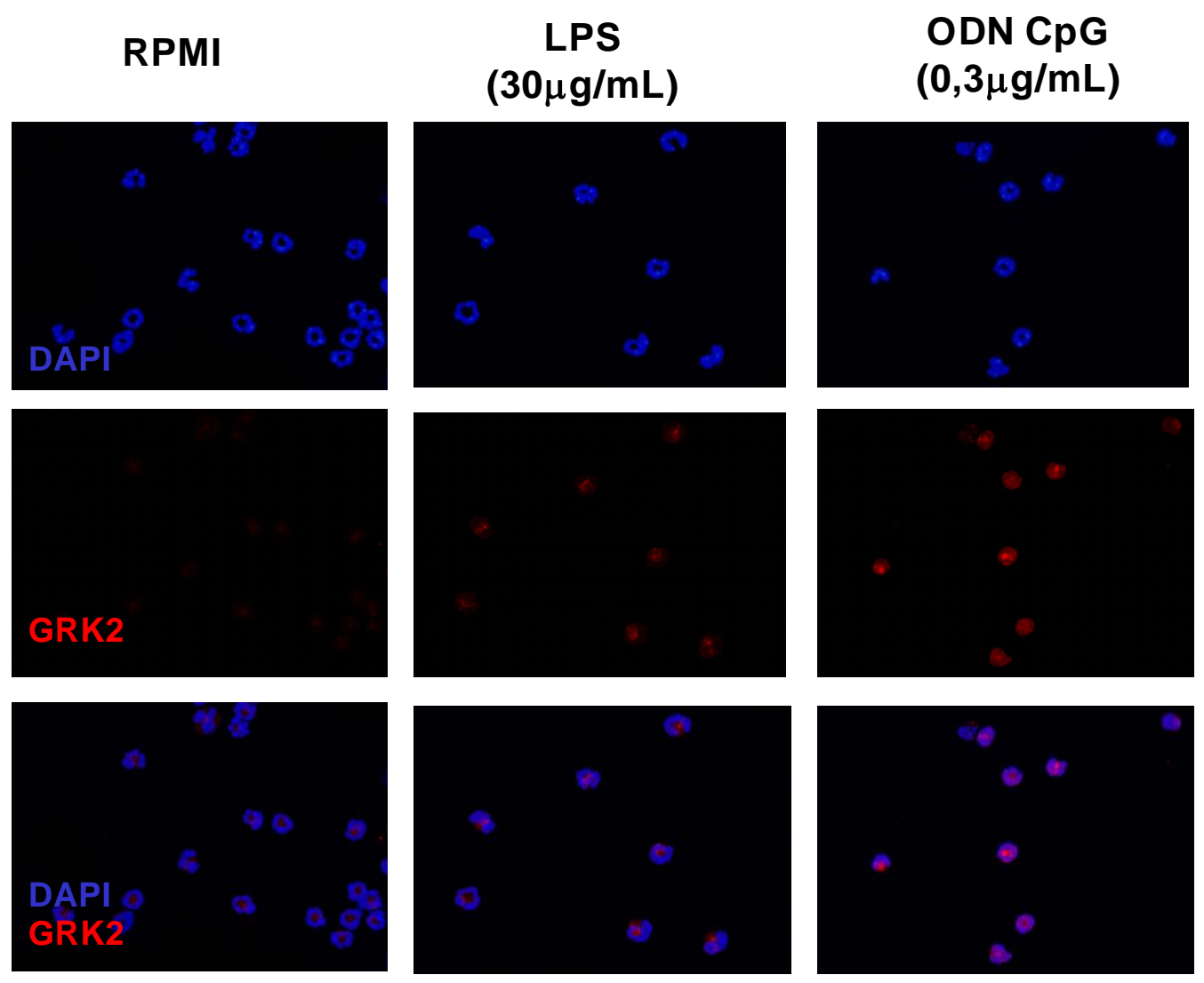

Figura 18. A ativação de TLR9 em neutrófilos aumenta a expressão de GRK2. Neutrófilos foram isolados da medula óssea de camundongos selvagens (C57BL/6) e incubados com ODN CpG $(0,3 \mu \mathrm{g} / \mathrm{mL})$, ou lipopolissacarídeo-LPS $(30 \mu \mathrm{g} / \mathrm{mL})$ em meio RPMI. Após duas horas foi verificada a expressão de GRK2 por imunofluorescência. As figuras são representativas de três experimentos realizados isoladamente. Para facilitar a leitura utilizou-se o 4, 6-diamidino-2-fenilindol (DAPI) para marcação da cromatina. 
A

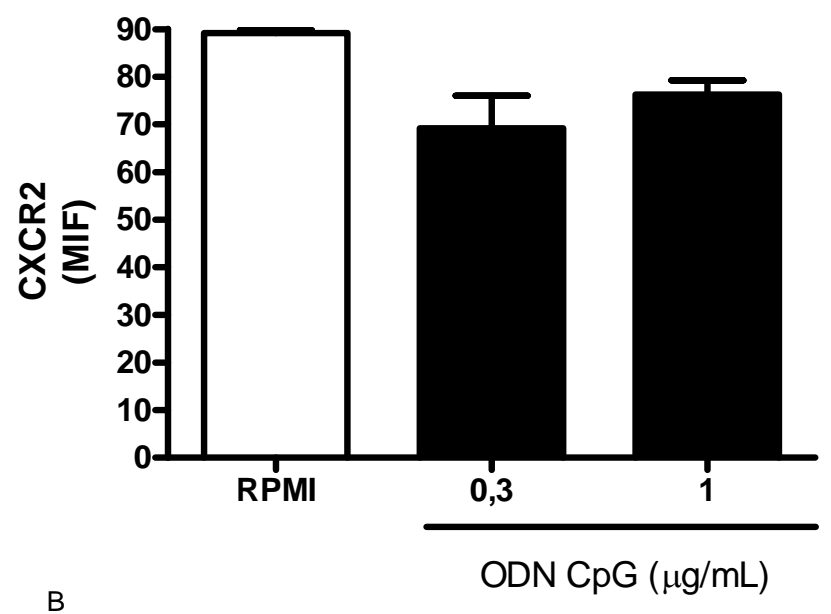

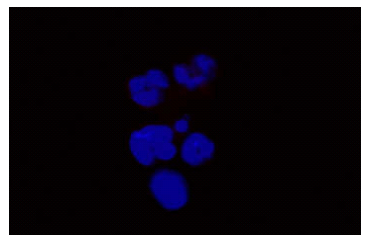

RPMI

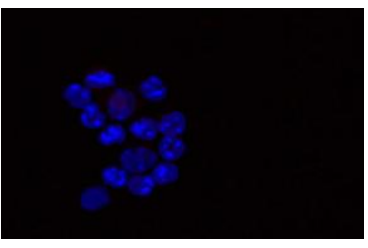

ODN CpG

$(0,3 \mu \mathrm{g} / \mathrm{mL})$

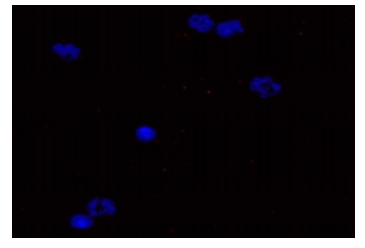

ODN CpG $(1 \mu \mathrm{g} / \mathrm{mL})$

Figura 19. A dessensibilização de CXCR2 e a indução da GRK2 em neutrófilos provocadas pela ativação de TLR9 são tempo-dependentes. Neutrófilos foram isolados da medula óssea de camundongos selvagens (C57BL/6) e incubados com ODN CpG em meio RPMI. Após uma hora foi verificada a expressão de CXCR2 em população Gr1 ${ }^{\text {high }}$ em citômetro de fluxo (a) e GRK2 por imunoflurescência (b). O gráfico para CXCR2 representa a mediana de intensidade de fluorescência (MIF). A expressão de GRK2 é representada pela associação da marcação pelo Alexa Flúor 594 (anticorpo secundário conjugado) concomitante a marcação da cromatina com o 4, 6diamidino-2-fenilindol (DAPI). As figuras são representativas de dois experimentos em triplicata realizados isoladamente. 

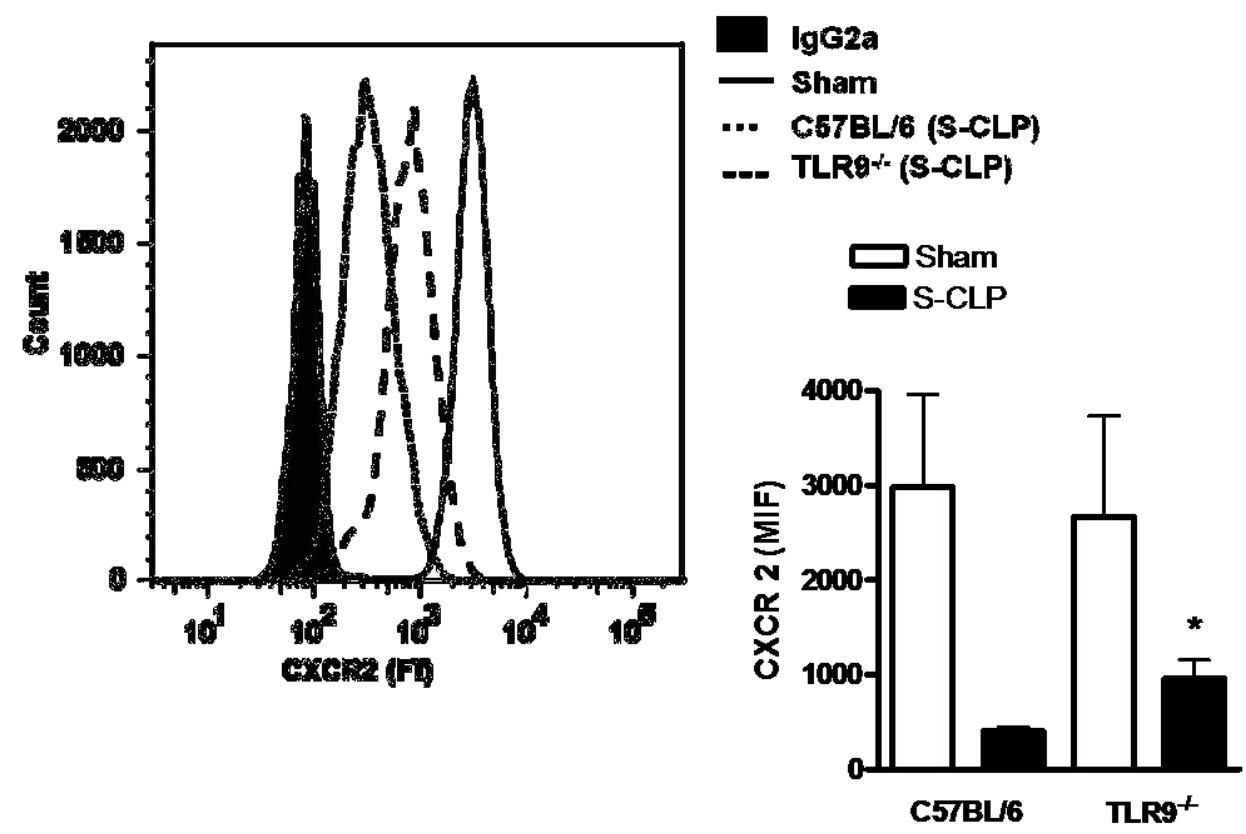

Figura 20. A deficiência de TLR9 previne a dessensibilização de CXCR2 em neutrófilos do sangue de animais submetidos à sepse severa (S-CLP). Camundongos selvagens (C57BL/6) ou deficientes de TLR9 $\left(\right.$ TLR9 $^{-1-}$ ) foram submetidos ao modelo de ligadura e perfuração do ceco (CLP) na forma de sepse severa (S-CLP). Os animais sham são controles falso-operados. Após duas horas da cirurgia os camundongos foram eutanasiados para obtenção do sangue. A expressão de CXCR2 foi verificada em população $\mathrm{Gr} 1^{\text {high }}$ em citômetro de fluxo. O histograma e gráfico representam a intensidade de fluorescência (FI) e mediana da intensidade de fluorescência (MIF), respectivamente. Para comparações entre os grupos utilizou-se ANOVA two way seguida do pós-teste de Bonferroni $(\mathrm{n}=5)$. * $\mathrm{p}<0,05$ em relação ao grupo S-CLP nos animais selvagens (C57BL/6). IgG2a: isotipo controle. 


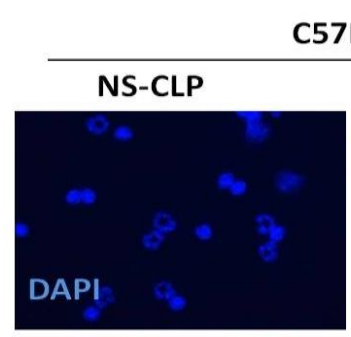

C57BL/6
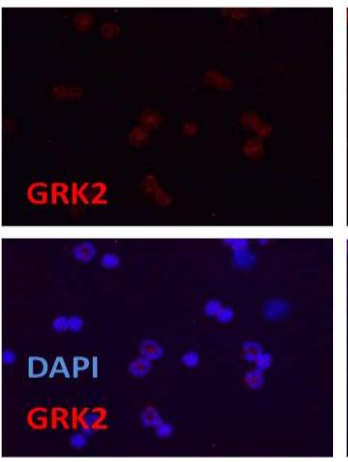
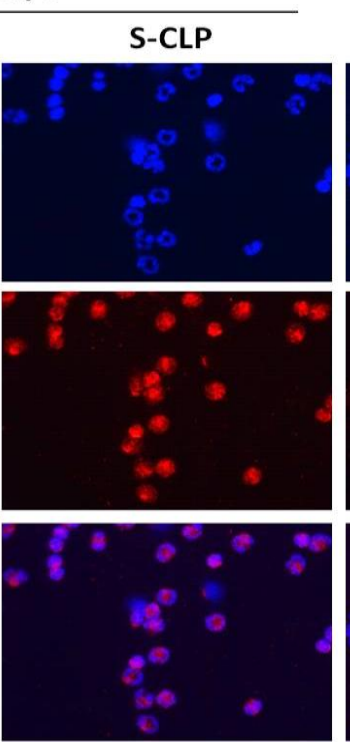

TLR9-/-
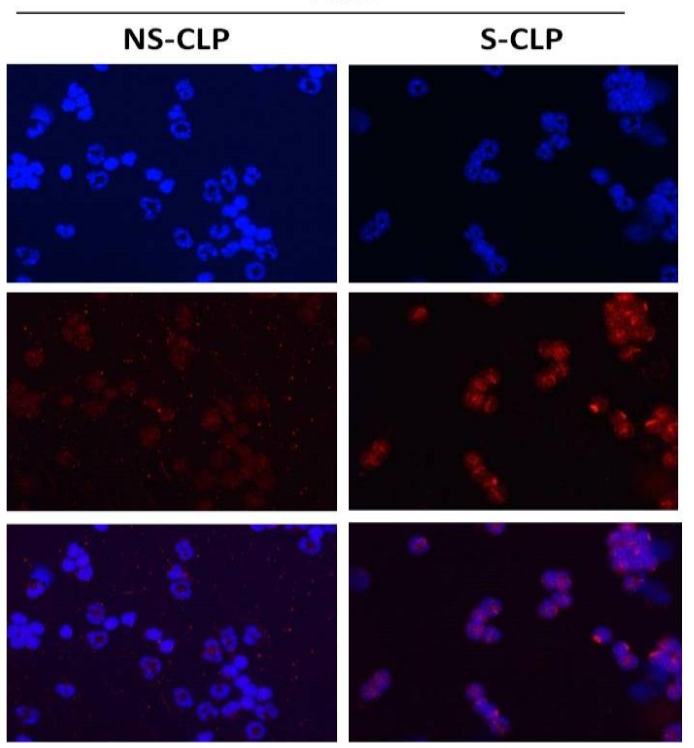

Figura 21. A deficiência de TLR9 previne a indução de GRK2 em neutrófilos do sangue de animais submetidos a sepse severa (S-CLP). Camundongos selvagens (C57BL/6) e deficientes de TLR9 $\left(\mathrm{TLR}^{-/}\right.$) foram submetidos ao modelo de ligadura e perfuração do ceco (CLP) em dois diferentes graus de severidade: sepse severa (S-CLP) e sepse não severa (NS- CLP). Após duas horas os animais foram eutanasiados e o sangue obtido por punção cardíaca $(n=3)$. A expressão de GRK2 foi verificada em pool de neutrófilos isolados do sangue utilizando imunofluorescência. As figuras são representativas de dois experimentos em triplicata realizados isoladamente. Para facilitar a leitura utilizou-se o 4, 6diamidino-2-fenilindol (DAPI) para marcação da cromatina. 


\subsection{A ativação de TLR9 aumenta a capacidade microbicida dos neutrófilos}

A ativação dos leucócitos na circulação via TLRs foi implicada em indução da produção de radicais derivados do oxigênio e nitrogênio resultando em lesão endotelial e corroborando para a falência orgânica em função da hipoperfusão dos tecidos (Brown et al., 2006). Enquanto a ativação de TLRs na circulação é prejudicial, no foco da infecção é benéfica, pois permite a dessensibilização de receptores quimiotáticos e aumento da capacidade fagocitária e microbicida dos fagócitos, essenciais para o combate dos agentes patogênicos (Takeuchi e Akira, 2010).

A ativação de TLR9 reduziu a quimiotaxia dos neutrófilos em direção a CXCL2, o que resultou em menor migração de neutrófilos para o foco inflamatório/infeccioso na sepse severa. A partir dessa ação de TLR9 semelhante aos demais TLRs, se buscou investigar a ação deste receptor sobre as funções fagocitária e microbicida dos neutrófilos.

A incubação de neutrófilos isolados da medula óssea durante duas horas com ODN CpG aumentou as capacidades microbicida (Figura 22a) e fagocitária (Figura 22b) em relação aos controles incubados somente com meio RPMI. Corroborando o aumento da função fagocitária, a ativação de TLR9 também elevou a polimerização de actina na presença de zimosan opsonizado (Figura 23).

O LPS induziu a polimerização de actina na presença de zimosan opsonizado mais precocemente quando comparado ao ODN CpG (Figura 23), o que pode, de certa forma, ser justificado pela localização do TLR9 no interior da célula, enquanto o TLR4 é encontrado na superfície. 
A

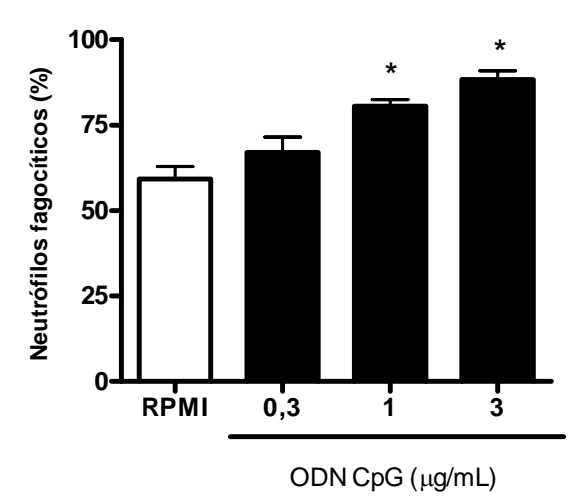

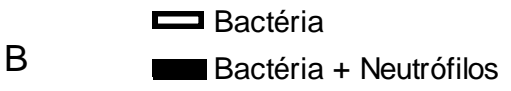

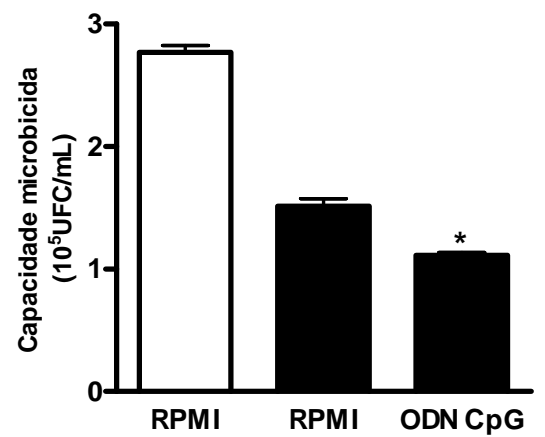

Figura 22. A ativação de TLR9 em neutrófilos aumenta a capacidade fagocitária e microbicida dos mesmos. Neutrófilos isolados da medula óssea de camundongos selvagens (C57BL/6) foram incubados com ODN CpG $(3 \mu \mathrm{g} / \mathrm{mL}) \mathrm{em}$ meio RPMI durante duas horas, e posteriormente submetidos ao ensaio de fagocitose (a) utilizando zimosan opsonizado (5 partículas/célula) e ensaio da capacidade microbicida (b) com bactérias do conteúdo cecal (2 bactérias/ célula). A porcentagem de células fagocíticas foi estabelecida pela contagem de 100 neutrófilos. Para comparação entre os grupos utilizou-se ANOVA one way seguida pelo pós-teste de Tukey. ${ }^{*} \mathrm{p}<0,05$. Os gráficos representam dois experimentos em triplicata realizados isoladamente. 


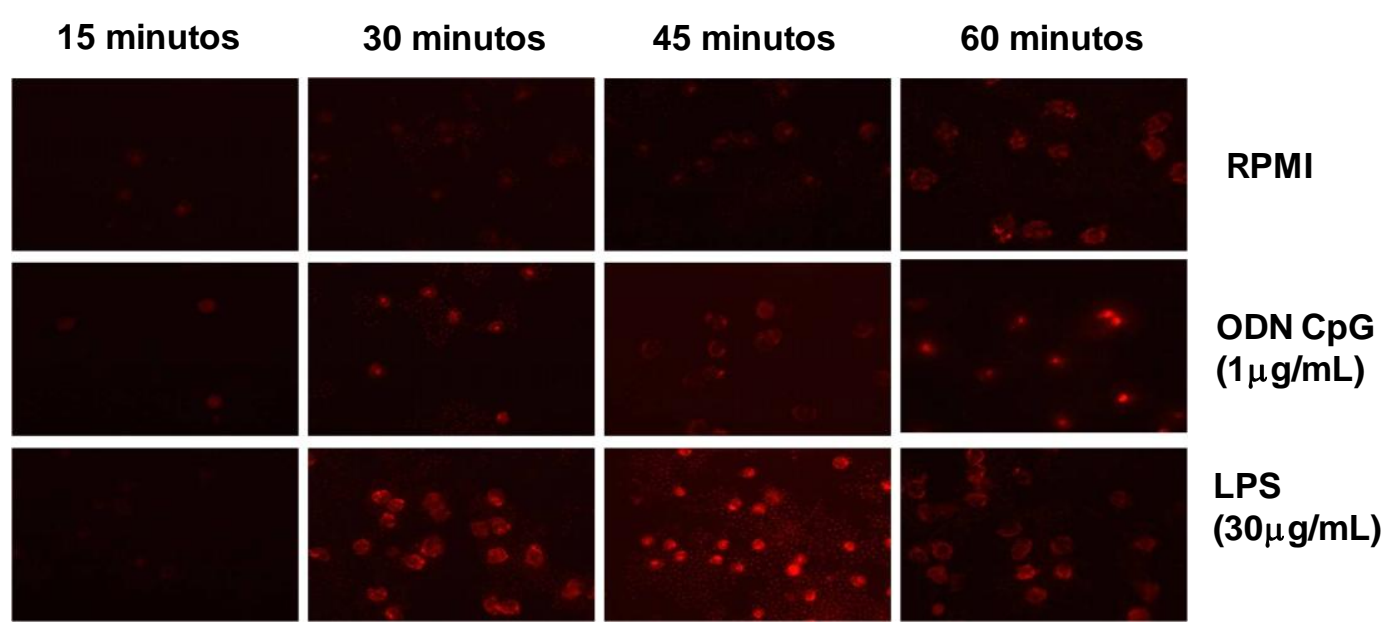

Figura 23. A ativação de TLR9 em neutrófilos aumenta a polimerização de actina na presença de zimosan opsonizado. Neutrófilos isolados da medula óssea de camundongos selvagens e incubados durante duas horas com ODN CpG $(1 \mu \mathrm{g} / \mathrm{mL})$ ou lipolissacarídeo- LPS $(30 \mu \mathrm{g} / \mathrm{mL})$ foram colocados na presença de zimosan opsonizado (5 partículas/célula) durante 15, 30, 45 e 60 minutos. A formação do polímero de F-actina foi verificada pela marcação de faloidina associada a rodamina em microscópio de epifluorescência mantendo-se o tempo de exposição para todos os grupos. As figuras representam dois experimentos em triplicata realizados isoladamente. 


\subsection{A ativação de TLR9 aumenta a produção de ROS e potencializa a produção}

\section{de NO por IFN- $\gamma$ pelos neutrófilos}

$\mathrm{O}$ aumento da fagocitose justifica em parte a maior capacidade microbicida dos neutrófilos incubados com o agonista de TLR9, porém pensou-se que a ativação de TLR9 pudesse também potencializar a produção de radicais derivados do oxigênio e nitrogênio por estes polimorfonucleares. De fato, o tratamento i.v. com ODN CpG $(0,9 \mathrm{mg} / \mathrm{Kg})$ elevou a produção de peróxido de hidrogênio em neutrófilos (população $\mathrm{Gr}^{+}$e $\mathrm{F} / 80^{-}$) após duas horas da administração em camundongos selvagens (Figura 24a). Além disso, a incubação de neutrófilos isolados da medula óssea com ODN CpG durante duas horas aumentou a produção de superóxido (Figura 24b).

A partir destes resultados, sugere-se que ativação de TLR9, por relaciona-se a acidificação lisossomal, possa ter favorecido a ativação do complexo enzimático NADPH oxidase e liberação de superóxido convertido pela superóxido dismutase em peróxido de hidrogênio.

Além da indução na produção de radicais derivados do oxigênio, a ativação de TLR9 também aumentou a produção de óxido nítrico por neutrófilos na presença de IFN-gama (Figura 25). Durante a sepse, a liberação de IFN-gama associada a ativação de TLR9 pode potencializar a produção de óxido nítrico, o qual foi anteriormente implicado na internalização de CXCR2 e inibição da migração dos neutrófilos (Rios-Santos et al, 2007). 
A

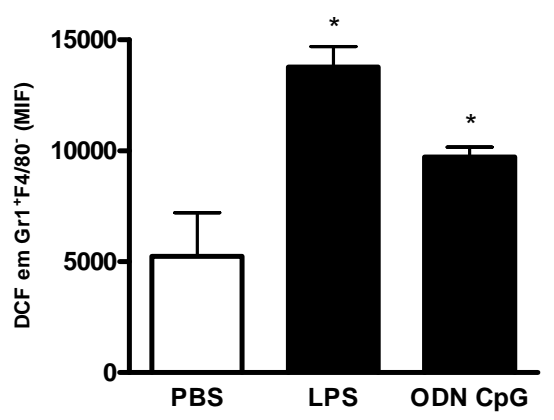

B

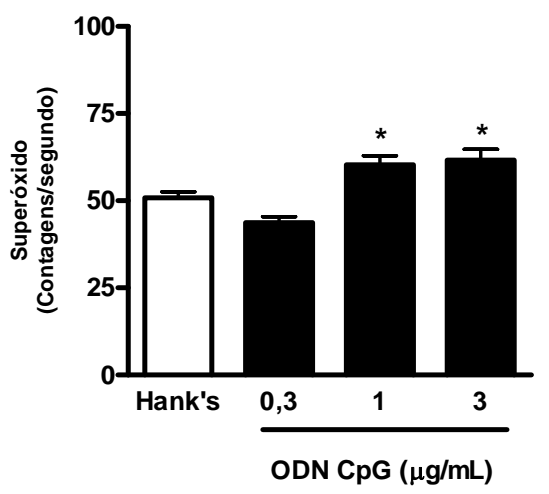

Figura 24. A ativação de TLR9 aumenta a produção de ROS pelos neutrófilos. A. Camundongos selvagens foram tratados com ODN $\mathrm{CpG}(0,9 \mathrm{mg} / \mathrm{kg})$, ou lipopolissacarídeo-LPS $(15 \mathrm{mg} / \mathrm{kg})$, ou solução salina tamponada/fosfatada (PBS) i.v. e após duas horas eutanasiados para obtenção de sangue por punção cardíaca $(n=5)$. No sangue total verificou-se a produção de peróxido de hidrogênio (a) por H2DCFDA em população $\mathrm{Gr}^{+}{ }^{+} \mathrm{F} 4 / 80^{-}$. O gráfico representa a média de intensidade de fluorescência (MIF) pelo DCF. B. Neutrófilos isolados da medula óssea de camundongos selvagens e incubados durante duas horas com ODN $\mathrm{CpG}$ foram submetidos ao ensaio de quimioluminescência com lucigenina $(20 \mu \mathrm{M})$. Para comparação entre os grupos utilizou-se ANOVA one way seguida pelo pós-teste de Tukey. ${ }^{*} \mathrm{p}<0,05$ em relação ao controle PBS ou Hank's. Os gráficos representam dois experimentos em triplicata realizados isoladamente. 


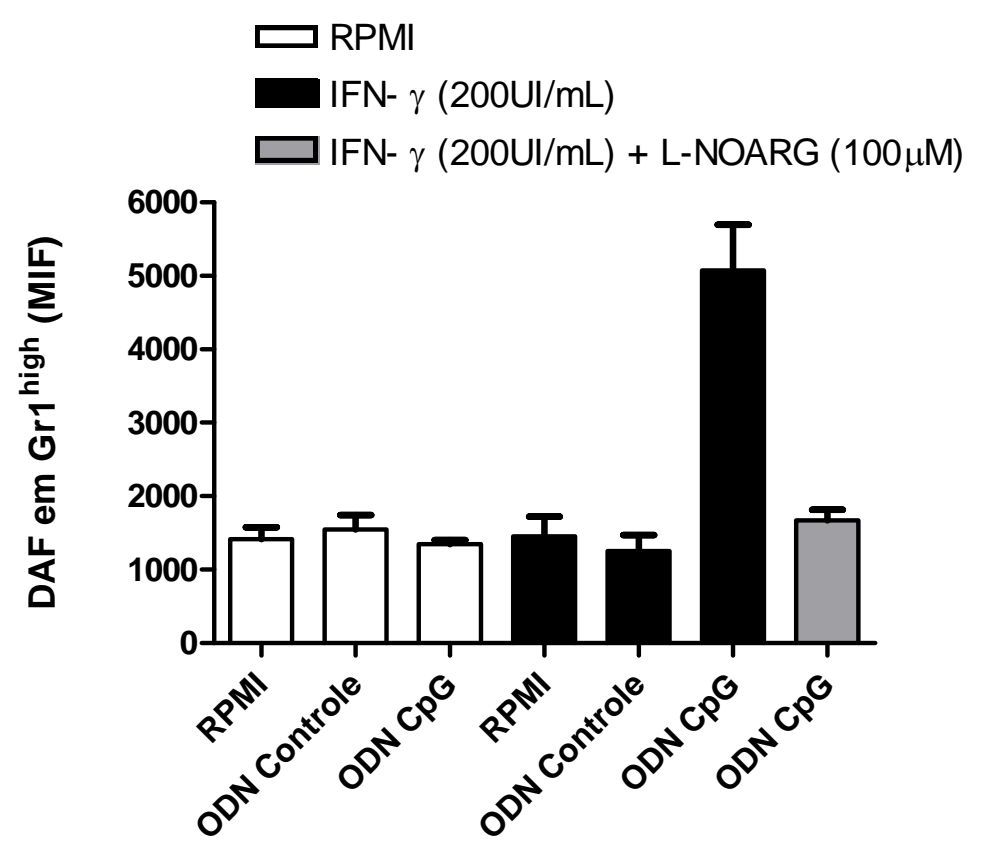

Figura 25. A ativação de TLR9 em neutrófilos aumenta a produção de NO na presença de IFN- $\boldsymbol{\gamma}$. Neutrófilos isolados da medula óssea foram incubados com 4amino-5-metilamino-2,7-diclorofluoresceína diacetato (DAF) na presença de LNOARG $(100 \mu \mathrm{M})$ em meio Hank's. As células foram lavadas com Hank's contendo L-Arginina $(100 \mu \mathrm{M})$ e incubadas durante duas horas com ODN Controle $(0,3 \mu \mathrm{g} / \mathrm{mL})$ ou ODN CpG $(0,3 \mu \mathrm{g} / \mathrm{mL})$ em meio RPMI, na presença ou não de IFN- $\gamma(200 \mathrm{UI} / \mathrm{mL})$. A produção de NO foi determinada por ensaio de citometria de fluxo, observando-se a marcação com DAF nas células Gr1 ${ }^{\text {high }}$. O gráfico representa a média de intensidade de fluorescência (MIF) obtida no experimento realizado em triplicata. Para a comparação entre os grupos, utilizou-se ANOVA one away seguida do pós-teste de Bonferroni. * ${ }^{*}<0,05$ em relação ao grupo ODN controle. 
6. Conclusão 
6.1 A ativação de TLR9 em neutrófilos do sangue é prejudicial na patogênese da sepse polimicrobiana por levar a dessensibilização de CXCR2 via aumento na expressão de GRK2 nos neutrófilos, o que impede a migração destes para o foco da infecção.

6.2 No foco da infecção, a ativação de TLR9 é benéfica por aumentar as capacidades fagocitária e microbicida dos neutrófilos, apesar da presença do receptor não ser indispensável para a realização destas funções. 
7.Referências 
ABBAS, A.K.; LICHTMAN, A.H. Imunologia celular e molecular. 5ed. Rio de Janeiro: Elsevier, 2005. Cap. 12. p. 283- 305.

AKIRA, S.;TAKEDA, K. Toll-like receptor signalling. Nat Rev Immunol, v.4, n.7, p.499-511, 2004.

ALVES-FILHO, J. C.;DE FREITAS, A.;RUSSO, M.;CUNHA, F. Q. Toll-like receptor 4 signaling leads to neutrophil migration impairment in polymicrobial sepsis. Crit Care Med, v.34, n.2, p.461-470, 2006.

ALVES-FILHO, J.C.; FREITAS, A.; SPILLER, F.; SOUTO, F.O.; CUNHA, F.Q. The role of neutrophils in severe sepsis. Shock, v. 30, n.1, p. 3- 9, 2008.

ALVES-FILHO，J. C.;FREITAS，A.;SOUTO，F. O.;SPILLER，F.;PAULA-NETO, H.;SILVA, J. S.;GAZZINELLI, R. T.;TEIXEIRA, M. M.;FERREIRA, S. H.;CUNHA, F. Q. Regulation of chemokine receptor by Toll-like receptor 2 is critical to neutrophil migration and resistance to polymicrobial sepsis. Proc Natl Acad Sci U S A, v.106, n.10, p.4018-4023, 2009.

ALVES-FILHO, J.C.; SÔNEGO, F.; SOUTO, F.O.; FREITAS, A.; VERRI, W.A.; AUXILIADORA, M.; BASILE, A.; MCKENZIE, A.N.; XU,D.; CUNHA, F.Q.; LIEW, F.Y. Interleukine-33 attenuates sepsis by enhancing neutrophil influx to the site of infection. Nature medicine, v.16, n.6, p.708-713, 2010a.

ALVES-FILHO, J.C.; SPILLER, F.; CUNHA, F.Q. Neutrophil paralysis in sepsis. Shock, v.34, SS1, p.15-21, 2010b.

ARRAES, S.M; FREITAS, M.S.; SILVA, S.V.; PAULA-NETO, H.A.; ALVESFILHO, J.C.; AUXILIADORA, M.M.; BASILE-FILHO, A.; TAVARES-MURTA, 
B.M.; BARJA-FIDALGO, C.; CUNHA, F.Q. Impaired neutrophil chemotaxis in sepsis associates with GRK expression and inhibition of actin assembly and tyrosine phosphorylation. Blood, v. 108, n.9, p. 2906- 2913, 2006.

AUFFRAY, C.; SIEWEKE, M.H., GEISSMANN, F. Blood Monocytes: Development, Heterogeneity, and Relationship with Dendritic Cells. Annual Review of Immunology, v.27, p.669- 692, 2009.

BABIOR B.M. NADPH oxidase. Current Opinion in Immunology, v. 16, n.1, p. 4247, 2004.

BARTHOLOMEU, D.C.; ROPERT, C.; MELO, M.B.; JUNQUEIRA, C.F.; TEIXEIRA, S.M. SIROIS, C.; KASPERKOVITZ,P.; LIEN, E.; GOLENBOCK, D.T.; GAZZINELLI, R.T. Recruitment and endo-lysosomal activation of TLR9 in dendritic cells infected with Trypanosoma cruzi. J Immunol, v. 181, n.2, p. 1333-1344, 2008.

BHAN, U.; LUCKACS, N.W.; OSTERHOLZER, J.J.; NEWSTEAD, M.W.; ZENG, X.; MOORE, T.A.; MCMILLAN, T.R.; KRIEG, A.M.; AKIRA, S.; STANDIFORD, T.J. TLR9 is required for protective innate immunity in gram-negative bacterial pneumonia: role of dendritic cells. The journal of Immunology, v. 179, p. 3937- 3946, 2007.

BLASIUS, A.L.; BEUTLER, B. Intracellular toll-like receptors. Immunity, v. 32, n.3, p.305-315, 2010.

BRINKMANN， M. M.;SPOONER， E.;HOEBE， K.;BEUTLER， B.;PLOEGH， H. L.;KIM, Y. M. The interaction between the ER membrane protein UNC93B and TLR3, 7, and 9 is crucial for TLR signaling. J Cell Biol, v.177, n.2, p.265-275, 2007. 
BENJAMIM, C.F.; SILVA, J.S.; FORTES, Z.B.; OLIVEIRA, M.A.; FERREIRA, S.H.; CUNHA, F.Q. Inhibition of leukocyte rolling by nitric oxide during sepsis leads to reduced migration of active microbicidal neutrophils. Infection and Immunity, v. 70, n. 7, p. 3602- 3610, 2002.

BROWN, K.A.; BRAIN, S.D.; PEARSON, J.D.; EDGEWORTH, J.D.; LEWIS, S.M.; TREACHER, D. F. Neutrophils in development of multiple organ failure in sepsis. Lancet, v. 368, n. 9530, p. 157- 169, 2006.

CAVASSANI, K.A.; ISHI, M.; WEN, H.; SCHALLER, M.A.; LINCOLN, P.M.; LUKACS, N.W.; HOGABOAM, C.M. KUNKEL, S.L. TLR3 is an endogenous sensor of tissue necrosis during acute inflammatory events. J Exp Med, v.205, n.11, p.26092621, 2008.

CHANDRA, A.; ENKHBAATAR, P.; NAKANO, Y.; TRABER, L.D.; TRABER, D.L. Sepsis: emerging role of nitric oxide and selectins. Clinics, v.61, n.1, p.71- 76, 2006.

CHIFFOLEAU, E.;HESLAN， J. M.;HESLAN， M.;LOUVET， C.;CONDAMINE, T.;CUTURI, M. C. TLR9 ligand enhances proliferation of rat CD4+ T cell and modulates suppressive activity mediated by CD4+ CD25+ T cell. Int Immunol, v.19, n.2, p.193-201, 2007.

CROSARA-ALBERTO, D.P.; DARINI, A.L.; INOUE, R.Y.; SILVA, J.S.; FERREIRA, S.H.; CUNHA, F.Q. Involvement of NO in the failure of neutrophil migration in sepsis induced by Staphylococcus aureus. British Journal in Pharmacology, v. 136, n. 5, p. 645- 658, 2002.

DAL-SECCO, D.; MOREIRA, A.P.; FREITAS, A.; SILVA, J.S.; ROSSI, M.A.; FERREIRA, S.H.; CUNHA, F.Q. Nitric oxide inhibits neutrophil migration by a 
mechanism dependent on ICAM-1: role of soluble guanylate cyclase. Nitric Oxide, v. 15, n.1, p.77- 86, 2006.

DURAMAD， O.;FEARON， K. L.;CHANG， B.;CHAN， J. H.;GREGORIO, J.;COFFMAN, R. L.;BARRAT, F. J. Inhibitors of TLR-9 act on multiple cell subsets in mouse and man in vitro and prevent death in vivo from systemic inflammation. $\mathbf{J}$ Immunol, v.174, n.9, p.5193-5200, 2005.

EL KEBIR, D.;JOZSEF, L.;FILEP, J. G. Neutrophil recognition of bacterial DNA and Toll-like receptor 9-dependent and -independent regulation of neutrophil function. Arch Immunol Ther Exp (Warsz), v.56, n.1, p.41-53, 2008.

EL KEBIR, D.;JOZSEF, L.;PAN, W.;WANG, L.;FILEP, J. G. Bacterial DNA activates endothelial cells and promotes neutrophil adherence through TLR9 signaling. J Immunol, v.182, n.7, p.4386-4394, 2009.

ELMAAGACLI, A. H.;KOLDEHOFF, M.;BEELEN, D. W. Improved outcome of hematopoietic SCT in patients with homozygous gene variant of Toll-like receptor 9. Bone Marrow Transplant, 2009.

FERGUSON, S.S.; ZHANG, J.; BARAK, L.S.; CARON, M.G. G-protein-coupled receptor kinases and arrestins: regulators of G-protein-coupled receptor sequestration. Biochem Soc Trans. v. 24, n.4, p.953-999, 1996.

FETEROWSKI, C.; WEIGHARDT, H.; EMMANUILIDIS， K.; HARTUNG，T.; HOLZMANN, B. Immune protection against septic peritonitis in endotoxin-primed mice is related to reduced neutrophil apoptosis. European Journal of Immunology, v. 31, n.4, p. 1268- 1277, 2001. 
HAYASHI, F.;MEANS, T. K.;LUSTER, A. D. Toll-like receptors stimulate human neutrophil function. Blood, v.102, n.7, p.2660-2669, 2003.

HEIT, B.; ROBBINS, S.M.; DOWNEY, C.M.; GUAN, Z.; COLARUSSO, P.; MILLER, B.J.; JIRIK, F.R.; KUBES, P.PTEN functions to 'prioritize' chemotactic cues and prevent 'distraction' in migrating neutrophils. Nature Immunology, v. 9, n.7, p.743-752, 2008.

INSTITUTO LATINO AMERICANO DE SEPSE. Campanha sobrevivendo a sepse razões para a campanha. Disponível em: < http://www.sepsisnet.org/ >. Acessado em 31 Maio 2008.

JANEWAY, C.A.; TRAVERS, P. WALPORT, M. SHLOMCHIK, M.J. Imunobiologia: o sistema imune na saúde e na doença. 6ed. Porto Alegre: Artmed, 2007. Cap.2. p. 37- 48.

JANETPOULOS, C.; FIRTEL,R.A. Directional sensing during chemotaxis. FEBS Letters, v. 582, n. 14, p.2075-2085, 2008.

JONG,S.D.; BASHA, G.; WILSON,.K.D.; KAZERN,M.; CULLIS, P.; JEFFERIES,W.; TAM, Y. The immunostimulatory activity of unmethylated and methylated CpG oligodeoxynucleotide is dependent on their ability to colocalize with TLR9 in late endosomes. J Immunol, v. 184, n.11, p. 6092-6102, 2010.

KAUFMANN I.; HOELZL A.; SCHLIEPHAKE F.; HUMMEL T.; CHOUKER A.; PETER K.; THIEL M. Polymorphonuclear leukocyte dysfunction syndrome in patients with increasing sepsis severity. Shock, v. 26, n. 3, p. 254-261, 2006. 
KHAN H.A. Zymosan-induced luminol-dependent chemiluminescence response of circulating and extravasated leukocytes in experimental sepsis. Mediators of Inflammation, v. 13, n. 2, p. 123-125, 2004.

KIM, Y. M.;BRINKMANN, M. M.;PAQUET, M. E.;PLOEGH, H. L. UNC93B1 delivers nucleotide-sensing toll-like receptors to endolysosomes. Nature, v.452, n.7184, p.234-238, 2008.

KLINMAN, D. M. Immunotherapeutic uses of $\mathrm{CpG}$ oligodeoxynucleotides. Nat Rev Immunol, v.4, n.4, p.249-258, 2004.

KONO, H.; ROCK, K.L. How dying cells alert the immune system to danger. Nature Reviews Immunology, v. 8, n.4, p.279-289, 2008.

KRIEG, A. M. Development of TLR9 agonists for cancer therapy. J Clin Invest, v.117, n.5, p.1184-1194, 2007.

LATZ, E.;SCHOENEMEYER, A.;VISINTIN, A.;FITZGERALD, K. A.;MONKS, B. G.;KNETTER, C. F.;LIEN, E.;NILSEN, N. J.;ESPEVIK, T.;GOLENBOCK, D. T. TLR9 signals after translocating from the ER to CpG DNA in the lysosome. Nat Immunol, v.5, n.2, p.190-198, 2004.

MACDONALD, J.; GALLEY, H.F.; WEBSTER, N.R. Oxidative stress and gene expression in sepsis. British Journal of Anaesthesia, v. 90, n.2, p.221- 232, 2003.

MARTIN, E.L.; SOUZA, D.G.; FAGUNDES, C.T.; AMARAL, B.; PUNTORIERI, V.; DEL SORBO, L.; FANELLI, V.; BOSCO, M.; DELSEDIME, L.; PINHO,.J.F.; LEMOS, V.S.; SOUTO, F.O.; ALVES-FILHO, J.C. CUNHA, F.Q.; SLUTSKY,A.S.; RUCKLE, T.; HIRISH, E. TEIXEIRA, M.M.; RANIERI, V.M. Phosphoinositide-3 
kinase gamma activity contributes to sepsis and organ damage by altering neutrophil recruitment. Am J Respir Crit Care Med., v.182, n. 6, p. 762-773, 2010.

MARTINS P.S.; KALLAS E.G.; NETO M.C.; DALBONI M.A.; BLECHER S.; SALOMÃO R. Upregulation of reactive oxygen species generation and phagocytosis, and increased apoptosis in human neutrophils during severe sepsis and septic shock. Shock, v. 20, n.3, p. 208-212, 2003.

MARTINS， P.S.; BRUNIALTI,M.K.; MARTOS， L.S.; MACHADO， F.R.; ASSUNÇÃO, M.S.; BLECHER, S.; SALOMÃO, R. Expression of cell surface receptors and oxidative metabolism modulation in the clinical continuum of sepsis. Crit Care, v. 12, n.1, p.1-10, 2008.

MILETIC,A.V.; GRAHAM, D.B.; MONTGRAIN, V.; FUJIKAWA, K.; KLOEPPEL, T.; BRIM, K.; WEAVER, B.; SCHREIBER, R.; XAVIER, R.; SWAT, W. Vav proteins control MyD88-dependent oxidative burst. Blood, v. 109, n.8,p. 3360-3368, 2007.

MOORE, C.A.; MILANO, S.K.; BENOVIC, J.L. Regulation of receptor trafficking by GRKs and arrestins. Annu Rev Physiol, v. 69, p. 451-482, 2007.

NOLAN, S.; DIXON, R.; NORMAN, K.; HELLEWELL, P.; RIDGER, V. Nitric oxide regulates neutrophil migration through microparticle formation. The American Journal of Pathology, v. 172, n.1, p. 265- 273, 2008.

NOVELLI G.P. Role of free radicals in septic shock. Journal of Physiology and Pharmacology, v. 48, n. 4, p. 517-527, 1997. 
O'BRIEN, M.C.; BOLTON, W.E. Comparison of cell viability probes compatible with fixation and permeabilization for combined surface and intracellular staining in flow cytometry. Cytometry, v. 19, n.3, p. 243-255, 1995.

PAULA-NETO, H.; ALVES-FILHO, J.C.; SOUTO, F.; SIPILLER, F.; AMÊNDOLA, R.S.; FREITAS, A.; CUNHA, F.Q.; BARJA-FIDALGO, C. Inhibition of guanilyl cyclase restores neutrophil migration and maintains bactericidal activity increasing survival in sepsis. Shock, 2010. Acesso em: 23 out, 2010. Disponível em: < http://www.ncbi.nlm.nih.gov/pubmed/20823697>.

PLITAS, G.;BURT, B. M.;NGUYEN, H. M.;BAMBOAT, Z. M.;DEMATTEO, R. P. Toll-like receptor 9 inhibition reduces mortality in polymicrobial sepsis. J Exp Med, v.205, n.6, p.1277-1283, 2008.

RANG,H.; DALE,.M.; RITTER,J. FLOWER, R Rang and Dales's Pharmacology.6ed. London: Churchill Livingstone, 2007. Cap.15. 844p.

RIOS-SANTOS, F.; ALVES-FILHO, J.C.; SOUTO, F.O.; SPILLER, F.; FREITAS, A.; LOTUFO, C.M.; SOARES, M.B.; SANTOS, R.R.; TEIXEIRA, M.M.; CUNHA, F.Q. Down-regulation of CXCR2 on neutrophils in severe sepsis is mediated by inducible nitric oxide synthase-derived nitric oxide. American Journal of Respiratory and Critical Care Medicine, v. 175, n. 5, p. 490- 497, 2007.

RITTER C.; ANDRADES M.; FROTA JÚNIOR M.L.; BONATTO F.; PINHO R.A.; POLYDORO M.; KLAMT F.; PINHEIRO C.T.; MENNA-BARRETO S.S.; MOREIRA J.C.; DAL-PIZZOL F. Oxidative parameters and mortality in sepsis induced by cecal ligation and perforation. Intensive Care Medicine, v. 29, n. 10, p. 1782-1789, 2003. 
ROTHENFUSSER， S.;TUMA， E.;ENDRES， S.;HARTMANN， G. Plasmacytoid dendritic cells: the key to CpG. Hum Immunol, v.63, n.12, p.1111-1119, 2002.

RUTZ，M.;METZGER，J.;GELLERT，T.;LUPPA，P.;LIPFORD，G. B.;WAGNER, H.;BAUER, S. Toll-like receptor 9 binds single-stranded CpG-DNA in a sequence- and pH-dependent manner. Eur J Immunol, v.34, n.9, p.2541-2550, 2004.

SHEPPARD F.R.; KELHER M.R.; MOORE E.E.; MCLAUGHLIN N.J.; BANERJEE A.; SILLIMAN C.C. Structural organization of the neutrophil NADPH oxidase: phosphorylation and translocation during priming and activation. Journal of Leukocyte Biology, v. 78, n.15, p.1025-1042, 2005.

SILVA, E.; PEDRO, M.D.E.A.; SOGAYAR, A.C.; MOHOVIC, T.; SILVA, C.L.; JANISZEWSKI, M.; CAL, R.G.; SOUSA, E.F.; ABE, T.P.; ANDRADE, J.; MATOS, J.D.; REZENDE, E.; ASSUNÇÃO, M.; AVEZUM, A.; ROCHA, P.C.; MATOS, G.F.; BENTO, A.M.; CORRÊA, A.D.; VIEIRA, P.C.; KNOBEL, E. Brazilian sepsis epidemiological study. Critical Care, v. 8, n.4, p. 251- 260, 2004.

SJÖLINDER, H.; MOGENSEN, T.H.; KILIAN, M.; JONSSON,A.B.; PALUDAN, S.R. Important role for Toll-like receptor 9 in host defense against meningococcal sepsis. Infect Immun, v. 76, n.11, p. 5421- 5428, 2008.

STADLBAUER, V.;MOOKERJEE, R. P.;WRIGHT, G. A.;DAVIES, N. A.;JURGENS, G.;HALLSTROM, S.;JALAN, R. Role of Toll-like receptors 2, 4, and 9 in mediating neutrophil dysfunction in alcoholic hepatitis. Am J Physiol Gastrointest Liver Physiol, v.296, n.1, p.G15-22, 2009. 
SOUTO, F.O.; ALVES-FILHO, J.C.; TURATO, W.M.; AUXILIADORA,M.; BASILE, A.; CUNHA, F.Q Essential Role of CCR2 in Neutrophil Tissue Infiltration and Multiple Organ Dysfunction in Sepsis.. Am J Respir Crit Care Med, 2010. Acesso em: 23 out, 2010. Disponível em: < http://www.ncbi.nlm.nih.gov/pubmed/20732989>.

TABETA， K.;HOEBE， K.;JANSSEN， E. M.;DU， X.;GEORGEL， P.;CROZAT, K.;MUDD, S.;MANN, N.;SOVATH, S.;GOODE, J.;SHAMEL, L.;HERSKOVITS, A. A.;PORTNOY, D. A.;COOKE， M.;TARANTINO, L. M.;WILTSHIRE, T.;STEINBERG, B. E.;GRINSTEIN, S.;BEUTLER, B. The Unc93b1 mutation 3d disrupts exogenous antigen presentation and signaling via Toll-like receptors 3, 7 and 9 . Nat Immunol, v.7, n.2, p.156-164, 2006.

TAKESHITA, F.;GURSEL, I.;ISHII, K. J.;SUZUKI, K.;GURSEL, M.;KLINMAN, D. M. Signal transduction pathways mediated by the interaction of CpG DNA with Tolllike receptor 9. Semin Immunol, v.16, n.1, p.17-22, 2004.

TAVARES-MURTA, B.M., ZAPAROLI, M., FERREIRA, R.B., VERGARA, M.L.S., OLIVEIRA, C.H.B., MURTA, E.F.C., FERREIRA, S.H., CUNHA, F.Q. Failure of neutrophil chemotactic function in septic patients. Critical Care Medicine, v. 30, p.16, 2002.

TORRES-DUEÑAS, D.; CELES, M.R.; FREITAS A.; ALVES-FILHO J.C.; SPILLER F.; DAL-SECCO D.; DALTO V.F.; ROSSI M.A.; FERREIRA S.H.; CUNHA F.Q. Peroxynitrite mediates the failure of neutrophil migration in severe polymicrobial sepsis in mice. British Journal of Pharmacology, v. 152, n. 3, p. 341-352, 2007.

TRAUTINGER F.; HAMMERLE A.F.; PÖSCHL G.; MICKSCHE M. Respiratory burst capability of polymorphonuclear neutrophils and TNF-alpha serum levels in 
relationship to the development of septic syndrome in critically ill patients. Journal of Leukocyte Biology, v. 49, n. 5, p. 449-454, 1991.

TSUKAHARA, Y.; MORISAKI, T.; KOJIMA, M.; UCHIYAMA,A.; TANAKA, M. iNOS expression by activated neutrophils from patients with sepsis. ANZ Journal of Surgery, v.71, n. 1, p. 15-20, 2001.

VÍCTOR V.M.; MIÑANO M.; GUAYERBAS N.; DEL RÍO M.; MEDINA S.; DE LA FUENTE M. Effects of endotoxic shock in several functions of murine peritoneal macrophages. Molecular and Cellular Biochemistry, v. 189, n. 1, p. 2-31, 1998.

VÍCTOR V.M., DE LA FUENTE M. Comparative study of peritoneal macrophage functions in mice receiving lethal and non-lethal doses of LPS. Journal of Endotoxin Research, v. 6, n.3, p. 235-241, 2000.

VICTOR, V.M.; ROCHA, M.; DE-LA-FUENTE, M. Immune cells: free radicals and antioxidants in sepsis. International Immunopharmacology, v. 4, n.3, p.327- 347, 2004.

YASUDA, H.; LEELAHAVANICHKUL, A.; TSUNODA, S.; DEAR, J.W.; TAKAHASHI,Y.; ITO, S.; HU, X,; ZHOU, H.; DOI, K.; CHILDS, R.; KLINMAN, D.M.; YUEN, P.S.T.; STAR, R.A. Chloroquine and inhibition of toll-like receptor 9 protect from sepsis-induced acute kidney injury. Am. J. Physiol. Renal Physiol., v. 294, p. F1050- F1058, 2008.

YABUKI, T.; TAKEYAMA,N. TSUDA, M.; TANAKA, T. NOGUCHI, H.; NAKATANI, T. CpG oligonucleotides activate the immune response in burned mice. J Surg Res., v.16, n. 1, p. 111-118, 2009. 
ZHANG,K.; RAOOF,M.; CHEN, Y.; SUMI, Y.; SURSAL,T.; JUNGER, W.; BROHI,K.; ITAGAKI, K. HAUSER, C.J. Circulating mitochondrial DAMPs cause inflammatory responses to injury. Nature, v.464, n.7285, p.104-107, 2010.

ZARBOCK, A.; LEY, K. Mechanisms and consequences of neutrophil interaction with the endothelium. The American Journal of Pathology, v. 72, n.1, p.1- 7, 2008.

WEIGHARDT, H.;HOLZMANN, B. Role of Toll-like receptor responses for sepsis pathogenesis. Immunobiology, v.212, n.9-10, p.715-722, 2007.

WENISCH C.; PARSCHALK B.; PATRUTA S.; BRUSTBAUER R.; GRANINGER W. Effect of polyclonal immunoglobulins on neutrophil phagocytic capacity and reactive oxygen production in patients with gram-negative septicemia. Infection, v. 27, n. 3,p. 183-186, 1999. 


\section{UNIVERSIDADE DE SÃO PAULO FACULDADE DE MEDICINA DE RIBEIRÃO PRETO}

— Comissão de Ética em Experimentação Animal -

\section{CE R T I F I C A D O}

Certificamos que o Protocolo para Uso de Animais em Experimentação $\mathbf{n}^{\circ} \mathbf{1 5 0 / 2 0 0 9}$, sobre o projeto intitulado "Papel do receptor Toll-like 9 na falência de migração dos neutrófilos na sepse", sob a responsabilidade do Professor Doutor Fernando de Queiroz Cunha está de acordo com os Princípios Éticos na Experimentação Animal adotado pelo Colégio Brasileiro de Experimentação Animal (COBEA) e foi APROVADO em reunião de 30 de novembro de 2009.

(We certify that the protocol $n^{\circ} 150 / 2009$, about "Role of the Toll-Like receptor 9 on failure of neutrophil migration in sepsis", agrees with the ETHICAL PRINCIPLES IN ANIMAL RESEARCH adopted by Brazilian College of Animal Experimentation (COBEA) and was approved by the College of Medicine of Ribeirão Preto of the University of São Paulo - Ethical Commission of Ethics in Animal Research (CETEA) in 11/30/2009 meeting.

Ribeirão Preto, 30 de novembro de 2009.

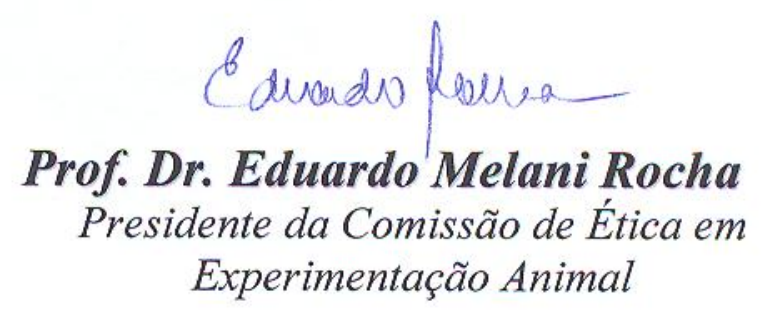

